[Vicino Oriente XXI (2017), pp. 5-57]

\title{
NEW ARCHAEOLOGICAL FEATURES IN BETHLEHEM (PALESTINE): THE ITALIAN-PALESTINIAN RESCUE SEASON OF NOVEMBER 2016
}

\author{
Lorenzo Nigro - Daria Montanari - Alessandra Guari - Maria Tamburrini - Pierfrancesco Izzo \\ Sapienza University of Rome \\ Mohammed Ghayyada - Iman Titi - Jehad Yasine \\ Ministry of Tourism and Antiquities - Department of Archaeology and Cultural Heritage
}

\begin{abstract}
During Autumn 2016 the Italian-Palestinian joint team of Sapienza University of Rome and the Ministry of Tourism and Antiquities of Palestine carried out further rescue excavations and surveying in the city of Bethlehem and in its surroundings. These activities were conducted in order to protect the archaeological and historical patrimony of this area of Palestine, and to prevent looting, sites destruction, vandalism and illegal trade of archaeological items. A provisional report on finds and activities is offered below.
\end{abstract}

Keywords: Bethlehem; Early and Middle Bronze Age; Iron Age; necropolis; archaeological and historical sites

\section{INTRODUCTION}

In November 2016 the joint team of the Palestinian MOTA-DACH and Sapienza University of Rome ${ }^{1}$ resumed rescue activities in the urban area of the city of Bethlehem, due to the accidental discovery of a new burial place at Jebel Dhaher, and with the aim of monitoring the situation in the necropolis of Khalet al-Jam'a (fig. 1). The second season at Bethlehem was in fact also suitable for continuing the graphic and photographic documentation and the study of finds from the tombs of the Khalet al-Jam'a necropolis. A special time was devoted to Tomb D13, called 'Barmil Tomb', an Iron Age II burial cave which illustrated the use of the necropolis also in the $1^{\text {st }}$ millennium BC. ${ }^{2}$ During the four weeks campaign, the team members visited several sites in order to check and document their preservation state. They collected all available data on a GIS platform ${ }^{3}$ which is now online in the open access website: www.lasapienzatojericho.it/Betlemme. A catalogue of checked sites is offered on $\S 2$. Paragraph 3. is devoted to finds from different burial places: the necropolises of Khalet al-Jam'a, Jebel Dhaher, Bardhaa, and the tomb of el-Atan. Finally, a short note (§ 4.) is devoted to the site of Khirbet el-Kôm - midway from Hebron to Tell ed-Duweir/ancient Lachish, and to one major archaeological site inside the town of Bethlehem, that is the cisterns known as David's Wells.

\section{SITES IN MAPS}

Natural (§ 2.1.), archaeological (§ 2.2.), historical (§ 2.3.) and cultural (§ 2.4.) sites, and monuments dating back from the beginning of the Early Bronze Age up to the Islamic Period have been monitored and surveyed during 2015 and 2016 seasons for the sake of

\footnotetext{
1 An Agreement on Cooperation establishing the joint Italian-Palestinian Expedition to Bethlehem was signed by Dr Jehad Yasine and Prof Lorenzo Nigro on $10^{\text {th }}$ April 2016.

2 Nigro et al. 2015, 192.

3 https://pf87.maps.arcgis.com/apps/MapJournal/index.html?appid=60b0495a716d400e97198e11070f8e2e.
} 
their protection and scientific valorisation. They were recorded and plotted in the Sapienza Expedition - MOTA-DACH GIS, developing a comprehensive archaeological map of the city of Bethlehem (fig. 2) and its surroundings (fig. 3). A detailed catalogue of these sites was then filled up, with relative chronology, occupational periods, archaeological/historical features, and main bibliographic references.

\subsection{Natural sites}

'Ain Artas/Aين ارطاس

ID: 001

Site location: lat. 31.687764429;

long. 35.185372585

State of preservation: preserved and rehabilitated

Occupational period: connected to the Aqueduct C

(Herodian period)

Elevation: $695 \mathrm{~m}$

Bibliography: Smith 1907, 124; Nigro 2015, 2.

\section{'Ain Battir/ عين بتير}

\section{ID: 002}

Site location: lat. 31.7272804680001;

long. 35.1384357090001

State of preservation: preserved

Occupational period: since $4^{\text {th }}$ millennium BC

Elevation: $650 \mathrm{~m}$

Bibliography: Levental 2010; Nigro 2015, 3.

\subsection{Archaeological sites}

\section{el-Atan/el-'Atn/العطن}

ID: 030

Site location: lat. 31.703926977;

long. 35.211158004

State of preservation: badly eroded

Occupational period: Early Bronze IV (el-Atan

Tomb § 3.3.), Iron, Hellenistic, Byzantine periods

Elevation: $733 \mathrm{~m}$

Disturbance: new constructions covering ancient necropolis

Bibliography: Gutman - Berman 1970, 583-585, fig. 3; Prag 2000, 177, fig. 3.

برضيعة/Bardhaa

ID: 029

Site location: lat. 31.684435029;

long. 35.2213540020001

State of preservation: preserved

Occupational period: Middle Bronze Age

Elevation: $664 \mathrm{~m}$

Disturbance: caves looted; site cut by streets.

\author{
عين صالح/Ain Salih' \\ ID: 003 \\ Site location: lat. 31.689172222; \\ long. 35.1704972220001 \\ State of preservation: preserved \\ Occupational period: connected to the Solomon's \\ Pool (from Hasmonean period until modern times) \\ Elevation: $794 \mathrm{~m}$ \\ Bibliography: Smith 1907, 124; Nigro 2015, 3.
}

\author{
'Ain el-Karmil (Birket al-Karmel)/

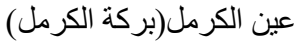 \\ ID: 012 \\ Site location: lat. 31.4241910170001; \\ long. 35.13497103 \\ Site extension: 0.9 ha ca. \\ State of preservation: preserved and rehabilitated \\ Occupational period: until modern times \\ Elevation: $805 \mathrm{~m}$.
}

Battir/Kh. el-Yahudiya/

Kh. el-Yahud/Betar Fortress/ تير

ID: 040

Site location: lat. 31.7300621326639;

long. 35.1353022154497

Site extension: 2.45 ha ca.

State of preservation: partially preserved

Occupational period: Middle Bronze II, Iron II,

Persian, Hellenistic, Roman, Byzantine, Islamic,

Ottoman periods

Elevation: $794 \mathrm{~m}$

Disturbance: modern dump

Bibliography: Clermont-Ganneau 1899, 463-470;

Nigro 2015, 2.

Battir Roman Bath/ الحمام الروماني في بتير

ID: 009

Site location: lat. 31.727374001;

long. 35.138594819

State of preservation: preserved and rehabilitated

Occupational period: Roman period

Elevation: $657 \mathrm{~m}$

Bibliography: Ussishkin 1993. 


\author{
Kh. Beit Bassa/Kh. el-Bedd/ \\ خربة بيت بصة/Bir Beit Bassa \\ ID: 007 \\ Site location: lat. 31.69232077; \\ long. 35.223518144 \\ Site extension: 2.6 ha ca. \\ State of preservation: preserved \\ Occupational period: Roman, Byzantine, \\ Early Islamic and Abbasid periods \\ Elevation: $660 \mathrm{~m}$ \\ Disturbance: altered by terracing and construction \\ of buildings on eastern and southern slopes of the \\ mound \\ Bibliography: Conder - Kitchener 1883, 87; Barukh \\ - Shorukh 1998, 98; Nigro 2015, 11.
}

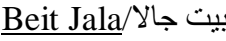

ID: 035

Site location: lat. 31.7163525441752;

long. 35.1873015748837

Site extension: 10 ha ca.

State of preservation: preserved

Occupational period: Persian, Hellenistic and Early

Roman periods (Khirbet Kabar); $1^{\text {st }}$ century AD

and Byzantine (Khirbet en-Najjar)

Bibliography: Barukh - Shorukh 2006; Hizmi -

Shabtai 1997.

بيت ساحور /

ID: 005

Site location: lat. 31.698297428;

long. 35.2309542360001

Site extension: 5 ha

State of Preservation: ruins

Occupational period: Early Bronze, Roman,

Byzantine, Islamic, Crusader periods

Elevation: $619 \mathrm{~m}$

Bibliography: Hennessy 1966; De Cree 1999;

Nigro 2015, 4-5.

جبل ظاهر/Jebel Dhaher

ID: 028

Site location: lat. 31.6948340370001;

long. 35.18991801

Site extension: 0.5 ha ca.

State of preservation: partially preserved

Occupational period: Early Bronze IV, Middle

Bronze II, Iron periods

Elevation: $800 \mathrm{~m}$

Disturbance: new buildings covered ancient necropolis.
Kh. el-Karmil necropolis/

مقبرة خربة الكرمل (fig. 4)

ID: 021

Site location: lat. 31.4234880270001;

long. 35.1459280220001

Site extension: 4 ha ca.

State of preservation: preserved

Occupational period: Early Bronze IV, Middle

Bronze I periods

Elevation: $771 \mathrm{~m}$

Bibliography: Dever 1975

Khalet al-Jama'a/خلة الجامع

ID: 033

Site location: lat. 31.6818666460001;

long. 35.2102333120001

Site extension: 5 ha ca.

State of preservation: partially preserved

Occupational period: Early Bronze IV, Middle

Bronze, Iron periods

Elevation: $667 \mathrm{~m}$

Disturbance: industrial factories covered partially the necropolis

Bibliography: Nigro 2015; Nigro et al. 2015.

Kh. el-Karmil wine press/

(fig. 5)

ID: 040

Site location: lat. 31.4223878808353;

long. 35.144882015879

Site extension: 0.14 ha ca.

State of preservation: preserved

Occupational period: Byzantine period

Elevation: $783 \mathrm{~m}$

Bibliography: Magness 2003, 99

Burj el-Karmil/Rujm el-Karmil/

(fig. 6)

ID: 016

Site location: lat. 31.4222599940001;

long. 35.1341829630001

Site extension: 0.12 ha ca.

State of preservation: partially preserved

nowadays excavations in the site are carried on by Dr. Issa Sarie' (Al-Quds University) and MOTA

Occupational period: Byzantine, Crusader periods Elevation: $814 \mathrm{~m}$

Bibliography: Conder - Kitchener 1883, 372-374;

Pringle 1997, 61. 


\author{
خربة الكوم/Kh. el-Kôm \\ ID: 018 \\ Site location: lat. 31.531110993; \\ long. 34.961203029 \\ Site extension: 5 ha ca. \\ State of preservation: partially preserved \\ Occupational period: Chalcolithic, Early Bronze I- \\ III, Middle Bronze, Iron, Persian, Hellenistic \\ periods \\ Elevation: $456 \mathrm{~m}$ \\ Disturbance: the ancient site is partially covered by \\ new village and by agricultural terracing \\ Bibliography: Dever 1969-1970; Holladay 1971a; \\ 1971b.
}

Jebel Qa'aqir/Rasm Qa'qir necropolis/ مقبرة جبل الكعاكي (fig. 7)

ID: 019

Site location: lat. 31.5222379940001; long.

34.951577

Site extension: 4 ha ca.

State of preservation: preserved

Occupational period: Early Bronze Age IV

Elevation: $408 \mathrm{~m}$

Disturbance: cultivation and agricultural terraces

Bibliography: London 1985; Dever 2014.

\section{Domestic cave of Jebel Qa'aqir/} مغارة السكن في جبل الكعاكير

ID: 020

Site location: lat. 31.5217570400001;

long. 34.954261975000

State of preservation: partially preserved

Occupational period: Early Bronze Age IV

Elevation: $398 \mathrm{~m}$

Disturbance: dense vegetation inside

Bibliography: Gitin 1975; Dever 1981.

\section{Qصر الكعاكير/Qasr el-Qa’aqir}

\section{ID: 025}

Site location: lat. 31.5269620340001;

long. 34.9606309640001

State of preservation: scanty remains

Occupational period: Early Bronze IV, Iron,

Byzantine, Ottoman periods

Elevation: $400 \mathrm{~m}$

Disturbance: modern road cut the ancient site

Bibliography: Dagan 2006, 68-70.
قبر راحيل/قachel's Tomb

ID: 031

Site location: lat. 31.7190922200001;

long. 35.202010237

State of preservation: preserved

Occupational period: remains of Roman aqueduct, Medieval, Ottoman periods

Elevation: $755 \mathrm{~m}$

Bibliography: Vetrali 1967; Tubb 1980; Nigro 2015, 7.

Roman Aqueduct (Lower Aqueduct)/

قناة المياه الرومانية السفلى

ID: 011

Site location: lat. 31.705766972;

long. 35.2046219630001

State of Preservation: partially preserved

Occupational period: Hasmonean-Herodian,

Ottoman periods

Elevation: $757 \mathrm{~m}$

Disturbance: section of a Lower Aqueduct is

incorporated within a souvenir shop on Manger

Street

Bibliography: Smith 1907, 125-127; Prag 2008.

برك سليمان/Solomon's Pools

ID: 008

Site location: lat. 31.6886690050001;

long. 35.1700994220001

Site extension: 3 ha ca.

State of preservation: preserved and rehabilitated

Occupational period: since Hasmonean period

Elevation: $790 \mathrm{~m}$

Bibliography: Murphy-O’Connor 1998, 425-428;

Prag 2008; Nigro 2015, 2-3, fig. 5.

Tekoa/Kh. Teku'a/ تقوع

ID: 010

Site location: lat. 31.634496991;

long. 35.210964968

Site extension: 12 ha ca.

State of preservation: scanty remains

Occupational Period: Early Bronze, Middle Bronze, Iron II, Roman, Byzantine, Mameluk, Crusader periods

Elevation: $816 \mathrm{~m}$

Bibliography: Saller, 1962, 153, 162; Escobar

1976; Herr 1986; Nigro, 2015, 11. 


\subsection{Historical sites}

\section{Al-Badd Giacaman Museum/}

\section{متحف بد جقمان}

ID: 013

Site location: lat. 31.7038930300001;

long. 35.2040600400001

State of preservation: restored in 2014

Occupational period: located in a traditional olive oil mill dated to $18^{\text {th }}-19^{\text {th }}$ century AD

Elevation: $765 \mathrm{~m}$

Bibliography: Nigro 2015, 2, fig. 2.

Cremisan Complex (Salesian Monastery, Salesian Sisters Convent and School, (دير كريمزان/(Cellars)

\section{ID: 039}

Site location: lat. 31.7268450434838.

long. 35.1723252398892

Site extension: 70 ha ca.

State of preservation: preserved

Occupational period: from Byzantine until modern times.

ابار داود/David's Wells

ID: 017

Site location: lat. 31.7093779800001;

long. 35.205297042

State of preservation: restored in 1962

Occupational period: Iron, Roman, Byzantine periods

Elevation: $770 \mathrm{~m}$

Disturbance: wells are in the Catholic Action Club

Bibliography: Bagatti 1952, 248-249; 1968, 223

236; Bagatti - Alliata 1980; Nigro 2015, 4; § 4.2.

The Green Market/Bethlehem Old Souk/ سوق الخضرة ( سوق بيت لحم القديم) ID: 015

Site location: lat. 31.7045629960001;

long. 35.204602014

State of Preservation: restored

Occupational period: since 1929

Elevation: $775 \mathrm{~m}$.

مغارة القديس جيروم/Grotto of St. Jerome

ID: 027

Site location: lat. 31.704569753;

long. 35.2076979280001

State of preservation: preserved

Occupational period: Roman, Byzantine, Crusader, until modern times

Elevation: $758 \mathrm{~m}$

Bibliography: Bagatti 1968, 139-140; Saller 1963,

325; Nigro 2015, 10
Note: this grotto is part of caves complex under the Nativity Church, composed, in addition to it, to the Navitiy Grotto, Grotto of Magi and the Manger, Grotto of St. Joseph, Altar of Innocents, and Tomb of St. Eusebius.

\section{Manger Square/سحة المهد}

ID: 022

Site location: lat. 31.7041100370001

long. 35.20616197

Site extension: 0.32 ha

State of preservation: renovated in 1998-1999

Occupational period: Iron Age until modern times Elevation: $762 \mathrm{~m}$

Bibliography: Nigro 2015, 2, 4, 6, 8.

\section{Milk Grotto/Magharet Sitti Mariam/} مغارة الحليب/Grotto of the Lady Mary

\section{ID: 023}

Site location: lat. 31.70343102;

long. 35.2087509720001

State of preservation: restored in 2007

Occupational period: $7^{\text {th }}$ century BC

Elevation: $762 \mathrm{~m}$

Bibliography: Bagatti 1952, 258-261; Nigro 2015, 10, fig. 9.

Mosque of Omar/ جامع عمر

ID: 037

Site location: lat. 31.7045411609862;

long. 35.205349898163

State of preservation: preserved

Occupational period: built in 1860, renovated in 1954.

كنيسة المهد/Nativity Church

\section{ID: 024}

Site location: lat. 31.7043280770001;

long. 35.2072808880001

State of preservation: preserved and restored

Occupational period: Roman, Byzantine, Crusader, until modern times

Elevation: $762 \mathrm{~m}$

Bibliography: Vincent - Abel 1914; Harvey 1937; Richmond 1936; Bagatti 1952, 9-69; Taha 2012; Nigro 2015, 9-11.

St. Catherine's Church/كنيسة القديسة كاترينا ID: 038

Site location: lat. 31.7045642251017;

long. 35.2077239268594

State of preservation: preserved

Occupational period: built in 1882, enlarged in

1949

Elevation: 759 m

Bibliography: Bagatti 1952, 218-224. 


\subsection{Sites of cultural interest}

Bethlehem Museum/ متحف بيت لحم (fig. 8)

ID: 032

Site location: lat. 31.7166889640001;

long. 35.201593831

Occupational period: Roman (section of stone pipe of Upper Roman Aqueduct passing through the museum)

Elevation: $753 \mathrm{~m}$

Bibliography: Vetrali 1967; Nigro 2015, 2, fig. 3.

Museum of the History of the City of

Bethlehem/Baituna al-Talhami

Museum/Bethlehem Folklore Museum/

متحف تاريخ مدينة بيت لحم

ID: 014

Site location: lat. 31.7048039750001; long. 35.204948019

State of preservation: preserved

Occupational period: two traditional Palestinian

houses host inside a collection of household items

Elevation: $774 \mathrm{~m}$

Bibliography: Nigro 2015, 2, fig. 4.

Salesian Complex

and International Nativity Museum/

متحف الميلاد الدولي ومجمع السلزيان

ID: 026

Site location: lat. 31.7064453240001;

long. 35.2027301310001

State of Preservation: preserved

Elevation: $781 \mathrm{~m}$

Bibliography: Nigro 2015, 2.

\section{BURIAL PLACES}

Four different burial places have been the object of rescue interventions during the Autumn 2016 season, all of them located within a radius of $1.5 \mathrm{Km}$ south of the Church of Nativity.

\subsection{Necropolis of Khalet al-Jam'a (n.033 in fig. 3)}

Further research activities at the site of Khalet al-Jam'a were carried out by the ItalianPalestinian Expedition in November 2016, with the aim of continuing the archaeological exploration of the recently discovered necropolis (fig. 9). ${ }^{4}$

The new inspection of the burial ground made it possible to ascertain that building activities for the industrial park are still going on over its northern part. The already damaged area has, unfortunately, undergone a - if possible - more drastic impact of new constructions: big warehouses have been erected enlarging the industrial quarter to the north-east in Area B. Moreover, to the south, in the southern part of previously untouched Area C, new structures have definitively obliterated Tombs B9, B10, B11 and C12 (fig. 10). ${ }^{5}$ Also in Area D (i.e. the Iron Age cemetery), new houses are under construction, even though the already excavated Tomb D13 (the 'Barmil Tomb') is still preserved as it was in 2015.

A survey was conducted on November 2016 in Area A, the only one kept completely safe from destruction, as it belongs to the al-Awqaf (because of the presence in the last century of an ancient small mosque).

First aim of the survey was to evaluate the preservation state of tombs identified in the first season (2015), and to assure that they had not been looted in the meantime. The second one was to collect further information about the history of the site during later periods, and to analyse scattered pottery fragments collected from the surface. Periods represented by

$4 \quad$ Nigro et al. 2015.

5 Nigro et al. 2015, 190-192. 
ceramics collected in Cemetery A are Middle Bronze ${ }^{6}$ and, mainly, Iron Age. Middle Bronze pottery consists of sherds of Simple Ware jars; Iron Age pottery consists of ridged neck Simple Ware jug, holemouth jar with cylindrical body, flat and unridged rim, and Cooking Ware. ${ }^{7}$

As regards Khalet al-Jam'a, the main goal of the second season, following up 2015 work, was recording and documenting, by means of descriptions, drawings and photos, Tombs A1, A2, C5, and D13, and their funerary sets. New finds from these tombs were also collected, and they are, thus, illustrated below.

\subsubsection{Tomb A1}

As regards Tomb A1, ${ }^{8}$ in the 2016 season it was possible to scan Chambers 2 and 4 (fig. 11). Chamber 2 is a round rock-cut underground room (3 $\mathrm{m}$ of diameter) with domed roof (1.2 $\mathrm{m}$ high), communicating to the north-west through a passage $0.9 \mathrm{~m}$ wide with Tomb A2. Chamber 4, to the south-west of Chamber 2, is accessible through a $1.3 \mathrm{~m}$-wide passage opened in the west side of Chamber 2. It has a niche along the south-western wall, large $0.38 \mathrm{~m}$, and to the east there is the blocked access to the shaft, $0.8 \mathrm{~m}$ large. The chamber is roughly round with domed roof, $3 \mathrm{~m}$ of diameter and $1.1 \mathrm{~m}$ high, and the floor is $0.6 \mathrm{~m}$ deeper than the one of Chamber 2. Also this chamber was surveyed with a 3D optical scanning device.

As regards Chamber 1, three more vases were found in it: a 'Gublite' bowl, BL6166, ${ }^{9}$ retrieved in Tomb A1 - Filling 1 (fig. 12), two fragmentary Black Burnished piriform juglets, ${ }^{10}$ respectively KJ.16.TA1.4/1 and KJ.16.TA1.4/2. ${ }^{11}$

In Chamber 4 the rim of a jug, KJ.16.TA1.4/3, was also found. ${ }^{12}$

\subsubsection{Tomb A2}

Two more pottery vessels were retrieved in Chamber 3, Filling 1 of Tomb A2: a White Slip bowl with flaring rim, pronounced shoulders and pedestal base, BL6171, ${ }^{13}$ and a dipper juglet with pinched rim, BL6172. ${ }^{14}$ They can be added to the funerary set already described, setting it in a MB IIB horizon (fig. 12). ${ }^{15}$

6 As it concerns the Middle Bronze Age chronology here followed see: Bietak (ed.) 2000; 2003; Bietak Czerny (eds.) 2002; 2007; Nigro 2008, 365-368.

7 Herzog - Singer-Avitz 2015, respectively 217, 221, 219, pls. 2.4.7:7; 2.4.15:3.

$8 \quad$ Nigro et al. 2015, 186-187.

9 Garstang 1933, pl. V:5. It is comparable with a carinated bowl from Tomb J45 of Tell es-Sultan Necropolis (Kenyon 1965, fig. 230:5).

10 Nigro 2003a, 351-353.

11 Ben-Arieh 2004, 13, fig. 2.10:38-49.

12 It can be added to the vases previously published (Nigro et al. 2015, 187). Pottery repertoire of Tomb A1 is consistent with Group II-IV typology outlined by K. Kenyon for Middle Bronze pottery from the Necropolis of Tell es-Sultan/Jericho (Kenyon 1960, 268-271; 1965, 268-271).

13 Kenyon 1960, fig. 191:3.

14 Garstang 1933, pl. XVII:6.

15 Nigro et al. 2015, 189; Halayqa 2015. Pottery equipment of Tomb A2 seems to correspond to that of Tomb Group III of Kenyon’s typology of Tell es-Sultan Necropolis (Kenyon 1965, 269). 


\subsubsection{Tomb C5}

Tomb $\mathrm{C} 5^{16}$ was, unfortunately, discovered by looters, which broke part of the rocky roof to pillage it. The following excavation by the Palestinian MOTA-DACH, in Spring 2014, allowed to collect what was left inside it.

The entrance to Tomb C5 was through a wide square shaft, $1.35 \times 1.55 \mathrm{~m}$, located to the south-east of an underground approximately square burial chamber. This is larger than the other of the same necropolis, as it measures $2.9 \times 3.5 \mathrm{~m}$, with a $1.9 \mathrm{~m}$-high domed roof, heavily damaged by collapses. The shaft is $1.5 \mathrm{~m}$ deep, and the passage between it and the chamber is only $0.8 \mathrm{~m}$ wide and $0.8 \mathrm{~m}$ high.

Inside the tomb, 628 pottery fragments were collected (figs. 13-15), which belonged to the most popular shapes and productions known from Middle Bronze II funerary sets: Black or Red Burnished piriform juglets with double handle (KJ.16.TC5.1/1, 2); ${ }^{17}$ White Slip bowls with flaring rim, pronounced shoulders and pedestal base (KJ.16.TC5.1/3), a very common type also in Jericho; Simple Ware jugs (KJ.16.TC5.1/4-5); Metallic Ware medium size jars (KJ.16.TC5.1/6-10); ${ }^{18}$ Storage/Transport Ware jars (KJ.16.TC5.1/11-13, including a pierced fragment: KJ.16.TC5.1/16), with fifty-six decorated jar walls, fourteen incised (KJ.16.TC5.1/13) and forty-two combed (KJ.16.TC5.1/14-15). This pottery material indicates that the tomb was primarily used during the Middle Bronze II. ${ }^{19}$

\subsubsection{Tomb D13 ('Barmil Tomb')}

A detailed plan of Tomb D13 ${ }^{20}$ was re-drawn at the end of the 2016 season (fig. 16). The round main chamber, $4 \mathrm{~m}$ of diameter, has a flat roof and it is $1.6 \mathrm{~m}$ high. The shaft is to the south-west of the chamber, $1.1 \mathrm{~m}$ wide, while to the north, in front of it, there is a raised niche $1.7 \mathrm{~m}$ wide and $1.3 \mathrm{~m}$ high, used as repository. The shape of the tomb is characterized by the location of the shaft, which is included within the limits of the circular cave. The underground circular tomb was characterized by the presence of a V-shaped installation made of stones (Bench 3), located roughly in the middle. Three depositional areas were, thus, identified, east of the installation (Filling 1), west of it (Filling 2), and inside it (Filling4). Installation B.3 was built up with middle size stones and a flat slab, 0.6 $\mathrm{m}$ long and $0.5 \mathrm{~m}$ wide, upon which human bones (mainly teeth; KJ.16.TD13.1.HR.1, 2) and several personal ornaments were found (bronze and iron earrings, carnelian beads, stamps, sea-shells).

In Filling 1 thirty-eight vessels were found (fig. 17): 1 miniature twin vase; 1 strainer; ${ }^{21}$ 2 one-spouted lamps; ${ }^{22} 5$ bowls ${ }^{23}$ (one Simple Ware, two Simple Painted, one Red Slip,

16 Nigro et al. 2015, 192.

17 These piriform juglets are comparable with those from Tomb 24 of Tell Beit-Mirsim (Ben-Arieh 2004, fig. 2.10:38-49).

18 Garfinkel - Cohen 2007, fig. 3.37:2. They can be compared with some specimens from Tell es-Sultan (Kenyon - Holland 1982, respectively figs. 128:5, 127:22, 25; 129:33, 30).

19 Pottery repertoire is widely comparable to that of Jericho Tomb Groups II-V, especially Storage jars mainly belong to B.1.a and b types (Kenyon - Holland 1982, figs. 191-193).

20 Nigro et al. 2015, 192. The 'Barmil Tomb' is the object of a dedicated publication in preparation where finds will be thoroughly illustrated.

21 Loud 1948, pl. 85:9. 
and one Red Burnished); 10 small Black Burnished juglets; ${ }^{24} 6$ pinched mouth dipper juglets; ${ }^{25} 3$ Simple Ware juglets; 5 Simple Ware jugs; ${ }^{26} 1$ stirrup storage jar; ${ }^{27} 3$ fragmentary cooking pots, and 1 jar. In Filling 2 (fig. 18) 2 one-spouted lamps, 1 high footed chalice, ${ }^{28} 7$ small Black Burnished juglets, ${ }^{29} 5$ Simple Ware jugs, 1 Line Painted juglet, and 1 Line Painted amphoriskos ${ }^{30}$ were retrieved. ${ }^{31}$ Moreover, a chalice with high foot from Filling1 and a Red Slip Painted jug plus a strainer-spouted jug from Filling2, already published in the first report, ${ }^{32}$ must be included to complete the funerary set of Tomb D13.

As it regards small finds, 37 objects were collected in Tomb D13, they mainly consist of bronze and iron bracelets, bronze and iron rings, numerous semiprecious beads, an udjateye, shells, bone items, one seal, one signet-ring seal, one ivory scarab, and one ivory pommel. ${ }^{33}$

A complete analysis of funerary equipment of Tomb D13 confirms a date from Iron IB up to Iron IIA-B.

\subsubsection{Human and animal remains from Khalet al-Jam'a necropolis [A.G.]}

Human and animal remains from Khalet al-Jam'a necropolis were collected within seven tombs (A1, A2, A4, B9, B10, C12, and D13). They are preliminarily analyzed in this paragraph and summarized in tab. 1.

The most common bone retrievals are human skulls, ${ }^{34}$ long bones, and teeth. As it regards animal remains, they are most often fragmentary long bones of ovicaprines, canides, and equids.

Sometimes bones have a whitish concretion attributable to the calcification caused by the limestone in which tombs were hewn.

\begin{tabular}{|c|l|l|}
\hline TOMB & \multicolumn{1}{|c|}{ HUMAN REMAINS } & \multicolumn{1}{|c|}{ ANIMAL REMAINS } \\
\hline Tomb A1 & $\begin{array}{l}\text { Chamber 1: mandible (KJ.15.TA1.1.HR.1), mandible } \\
\text { (female; KJ.15.TA1.1.HR.2), mandible and teeth (child; } \\
\text { KJ.15.TA1.1.HR.3). }\end{array}$ & $\begin{array}{l}\text { Chamber 1: crania (dog), } \\
\text { tarsus, calcaneus, teeth (horse) } \\
\text { (KJ.15.TA1.1.FR.1). }\end{array}$ \\
\hline Tomb A2 & $\begin{array}{l}\text { fragmentary skull, teeth, humerus sx, clavicle, ulna, phalanx } \\
\text { (KJ.15.TA2.1.HR.1). }\end{array}$ & $\begin{array}{l}\text { teeth, mandible, carpus/tarsus, } \\
\text { long bones }\end{array}$ \\
\hline
\end{tabular}

Herzog - Singer-Avitz 2015, 217, pl. 2.4.8:7-9.

23 Herzog - Singer-Avitz 2015, pl. 2.4.1:5, 7-8.

24 Tufnell 1953, pl. 88:309; Tubb 1980, pl. I:3.

25 Herzog - Singer-Avitz 2015, 217.

26 Yezerski 2004, pl. 4:13-14; Herzog - Sineger-Avitz 2015, 221, pl. 2.4.12:1-3.

7 Albright 1932, pls. 53(A):1; 54(A):1; Yezerski 1997, 32, ns. 17-18.

8 Herzog - Singer-Avitz 2015, pl. 2.4.2:1.

29 Peleg - Yerzeski 2004, pl. 6:23, 26-27.

30 Herzog - Singer-Avitz 2015, pl. 2.4.6:4.

314 lamps and 7 small Black Burnished juglets are already illustrated in Nigro et al. 2015 (fig. 31:1-2).

Nigro 2015, fig 18; Nigro et al. 2015, fig. 32.

33 Nigro et al. 2015, 192-193.

34 Skulls are indicators of sex of individuals when sexual dimorphism characteristics are marked and clear, and allow it (Acsádi - Nemeskéri 1970; Canci - Minozzi 2005, 119, tab 8.1). 


\begin{tabular}{|l|l|l|}
\hline & \multicolumn{1}{|c|}{} & (KJ.15.TA2.1.FR.1). \\
\hline Tomb A4 & skull (KJ.15.TA4.1.HR.1) & $\begin{array}{l}\text { fragmentay bones } \\
\text { (KJ.15.TA4.1.FR.1) }\end{array}$ \\
\hline Tomb B9 & $\begin{array}{l}\text { skulls (two individuals; KJ.15.TB9.1.HR.1, } \\
\text { KJ.15.TB9.1.HR.2), mastoid process (two), ribs, sternum, } \\
\text { scapula, vertebrae (thoracic, lumbar), phalanges, metatarsus, } \\
\text { astragalus, fragmentary humerus (KJ.15.TB9.1.HR.3) }\end{array}$ & $\begin{array}{l}\text { fragmentary bones } \\
\text { (KJ.15.TB9.1.FR.1) }\end{array}$ \\
\hline Tomb B10 & $\begin{array}{l}\text { Chamber 2: skull, mandible, teeth, long bones } \\
\text { (KJ.15.TB10.1.HR.1) }\end{array}$ & $\begin{array}{l}\text { fragmentary bones } \\
\text { (KJ.15.TB9.1.FR.1) }\end{array}$ \\
\hline Tomb C12 & $\begin{array}{l}\text { skull, atlas, teeth, vertebrae, clavicle, humerus (two), radius } \\
\text { (two), phalanx, ribs fragments, coccyx, pelvis fragments, } \\
\text { femurs (two), tibia (two), fibula (KJ.15.TC12.1.HR.1) }\end{array}$ & $\begin{array}{l}\text { mandible, teeth, humerus, tibia, } \\
\text { ulna (KJ.15.TC12.1.FR.1) }\end{array}$ \\
\hline Tomb D13 & $\begin{array}{l}\text { 3 lower incisors, 1 upper incisor (KJ.16.TD13.1.HR.1); } \\
\text { 2 upper incisors, 4 molars, 4 pre-molars }\end{array}$ & - \\
(KJ.16.TD13.1.HR.2) & \\
\hline
\end{tabular}

Tab. 1 - Quantity and kind of human and animal remains collected in Khalet Jam'a necropolis.

Human remains ${ }^{35}$ found in Tomb A1 include: a fragmentary mandible (right side; KJ.15.TA1.1.HR.1); a small human slightly pointed mandible (toothless) presumably belonging to a young female (KJ.15.TA1.1.HR.2); and a nearly complete mandible, left side, plausibly of a sub-adult (KJ.15.TA1.1.HR.3). The autopsy of teeth inside the latter one revealed that two incisors in the distal part of the crown exhibit three small cusps. On their surfaces, it is possible to observe the phenomenon of enamel hypoplasia, ${ }^{36}$ both vertical (one central line), and horizontal (at the base of the collar). A case of eruption out of the socket can be noticed in the inner-lingual part of the incisors, perhaps due to the eruption of a permanent tooth replacing a deciduous one. Both observations suggest that the young individual of Tomb A1 was in the growing age at the moment of the death, around seven years old.

As concerns animal bones from Tomb A1, the most relevant finds are two fragmentary skulls of dogs (one puppy). Some fragmentary long bones, a metatarsal, a tarsus, a calcaneus of ovicaprine and equids, as well as four teeth of horse/donkey were also collected (KJ.15.TA1.1.FR.1).

Human remains retrieved in Tomb A2 are: a left humerus, a phalanx, two fragments of a skull, a clavicula, and an ulna (KJ.15.TA2.1.HR.1). Animal bones are represented by fragmentary long bones, teeth, mandible, and carpus or tarsus (KJ.15.TA2.1.FR.1). Animal long bones bear signs of butchering, probably due to the use of a scraper. They possibly were part of a food offering.

In Tomb A4, a human skull was found (KJ.15.TA4.1.HR.1). It shows female characteristics, as the pronounced right frontal bone, and an approximate age of 25-30 years.

In Tomb B9, two more human skulls were found. The first one (KJ.15.TB9.1.HR.1) has marked supraorbital margin, eyebrow arch and glabella. Cranial sutures are almost entirely

35 Bones found in Tomb A1 were partially damaged on their outer cortex by fungi and bacteria.

36 Dental enamel hypoplasia is an indicator of health and nutrition conditions, it can occur only during childhood, when the enamel of crown develops, recording episodes of disease or malnutrition in this fundamental phase of the human life (Canci - Minozzi 2005, 211). 
obliterated suggesting that it belonged to a mature male adult. The second skull (KJ.15.TB9.1.HR.2; fig. 19) could belong to a young (female?) individual, according to the smoothed and straight forehead, rounded eye sockets, the junction point of the nose close to the front, slight occipital protuberance, pronounced right frontal bone, sutures in some places are not yet calcified. Furthermore, it presents an epigenetic variation on front bone: the furrow ${ }^{37}$ goes from the nasal area to the wall. ${ }^{38}$ This feature looks like a rare character, because it is usually attested up to the age of three/four years. In this case, it occurs in an adult, or in a young individual showing a praecox sexual dimorphism. The cranial sutures are open up to $1 \mathrm{~cm}$, from bregma the suture is fully open $(1.8 \mathrm{~cm})$, all over the skull. It is $14 \mathrm{~cm}$ wide and $17 \mathrm{~cm}$ long, the thickness of the crown ranges from 0.3 to $0.7 \mathrm{~cm}$. Also two fragmentary mastoid processes (one short, pointed and curve, long $2.9 \mathrm{~cm}$ and wide $1.1 \mathrm{~cm}$; the second $1.3 \mathrm{~cm}$ wide, without the distal part), thus, point to a presumable age of 15-18.

The other human bones found in Tomb B9 are ribs, sternum, scapula, vertebrae (thoracic, lumbar), phalanges, metatarsus, astragalus, and fragmentary humerus (KJ.15.TB9.1.HR.3) difficult to be attributed to previous individuals.

Inside Chamber 2 of Tomb B10 a further human skull was found just before the northwestern wall, facing up, about $50 \mathrm{~cm}$ from a mandible, and near long bones (KJ.15.TB10.1.HR.1; fig. 20). The skull presents some marked features: the glabella and eyebrow arch, the occipital protuberance is pronounced, and the mastoid process is large and rounded, suggesting the identification with a male individual. It can be also noted the disappearance of the coronal suture, especially of the bregma, and of sagittal suture. Medium-lambda and lambda result in synostosis more than 50\%, therefore the age of death is in the range 35-45 years. During the excavations a mandible was also found. It is robust, with marked features, and pronounced chin, thick bottom margin with a single tooth (fractured penultimate molar). Dental alveolus are small. ${ }^{39}$ Right humerus and mandible have mummification traces, probably due to the deposition in the cave. These rests, thus, belong to the same male individual.

Some fragmentary and mixed animal bones were also recovered in this tomb.

An almost complete skeleton (KJ.15.TC12.1.HR.1) was found in Tomb C12. The skull (fig. 21) has large, rounded and vertical mastoid processes. Supraorbital margin, as well as the brow ridge and glabella, is quite wide, nuchal plane presents a pronounced superior line; the frontal and parietal bumps are just slightly pronounced. The skull is $13 \mathrm{~cm}$ width, maximum $20 \mathrm{~cm}$ length, $16 \mathrm{~cm}$ height, and $0.4 \mathrm{~cm}$ thick. Twelve teeth are in the upper arch (there are two central incisors and the last right molar, while the second upper molar is missing in the left side). Some thin horizontal lines testify the presence of enamel hypoplasia. Skeletal remains also included the atlas, four vertebrae, a clavicula, two shoulders, two radios, a phalanx, a coccyx, the right pelvis, two femura, two tibias, a fibula,

37 The furrow is the median suture of the frontal bone, which brings together the two symmetrical halves of the bone, corresponding to the two primitive ossification points. It tends to disappear with the ageing, in the event of persistence this phenomenon is called metopism.

38 An abnormality of bone fusion can be identified on this skull. Component part of a bone may fail to fuse together, or normally discrete skeletal structures may instead be fused. In foetus, frontal bone is formed via intra-membranous ossification from two halves which make up the left and right bone. On occasion, however, they fail to unite, so that the division persists. This suture is called the metopic suture (Mays 2010, 184).

39 In this case the loss during the lifetime of some teeth and the total healing of the bone tissue can be identified. 
and seven fragmentary ribs. All these observations suggests that the skeleton was of a young male of 20-30 years.

In the same tomb also some fragmentary animal bones were collected.

In Tomb D13 some human remains were upon a flat slab of the V shaped installation B.3, they were: 3 lower incisors mineralized, amongst these one deciduous, and 1 upper incisor (KJ.16.TD13.1.HR.1); 2 upper incisors, 4 molars, one with tooth decay, and 4 premolars (KJ.16.TD13.1.HR.2).

Human remains recovered in tombs of Khalet al-Jam'a seem to be related to primary, single, as it is in the case of Tomb C12, multiple, as in the case of Tomb B9, and maybe familiar, as in the case of Tomb A1, depositions, dating back from Early Bronze IV and Middle Bronze Age II, accompanied by funerary sets, mainly consisting of pottery and weapons.

\subsection{Necropolis of Jebel Dhaher (rescue excavations 2016; $n$. 028 in fig. 3)}

The site lays $1.95 \mathrm{~km}$ south-west from the centre of Bethlehem, directly to the southwest of the new souk and to the east of the Al-Ahlia University, in a land owned by the Palestinian Army (figs. 22-23). Geologically the area is composed by a friable whitish chalky limestone spur, the local bedrock, overlaid by reddish-brown soil. Jebel Dhaher necropolis was brought to light by chance on $1^{\text {st }}$ October 2016 during construction works for a military compound. The site is on a regular flat bedrock berm at $714 \mathrm{~m}$ a.s.l. The necropolis is distinguished by shaft-tombs, with circular shafts and generally a single round domed chamber, distributed with a noticeable density.

Three tombs (Tombs 1-3) were dug by MOTA-DACH in the days of their accidental discovery (early October), while the other three (Tombs 4-6) were identified when a proper rescue intervention begun on Saturday $12^{\text {th }}$ November 2016, with the participation also of the Italian Team of Sapienza University of Rome which already worked in Khalet Jam'a in 2015 (fig. 24).

Three more tombs (Tomb A, B, C) had already been discovered in 2003 along the western boundary wall of the compound. They were cut by bulldozers in an area slightly westwards and higher in elevation in respect of the tombs discovered in Autumn 2016. When work started at Jebel Dhaher, in 2016, Tomb A (fig. 25), the southernmost one, was still visible, while the other two tombs (B and C) had already been buried under a concrete wall. Tomb A was sliced on its north-south axis, and, according to what it was observable, it was $2.7 \mathrm{~m}$ long. It originally consisted of a domed chamber reached by a vertical round shaft. The chamber was filled up with collapsed limestone chops. Some human bones were collected inside it in 2003; ceramic material retrieved inside dates from Middle Bronze II. ${ }^{40}$ Unfortunately, on November $18^{\text {th }} 2016$, also Tomb A was concealed under the concrete wall.

The necropolis of Jebel Dhaher was in use, according to architectural features of tombs and findings within them (see below), from the Early Bronze IVB/Intermediate Bronze Age up to the Middle Bronze Age, with a possible (maybe restricted) use during the Iron Age (documented only for Tomb 5).

40 Local office of the MOTA-DACH, personal communication. 


\subsubsection{Tomb 1}

The identification of Tomb 1 was due to the discovery of the nearby Tomb 2, the first to be brought to light at the site in 2016. In fact, when Tomb 2 was discovered, the bulldozer shovel accidentally broke the rocky diaphragm separating the two tombs, allowing the archaeologists to notice the presence of Tomb 1 . Tomb 1 was a familiar tomb, apparently used for two or more generations during Middle Bronze Age I-II (fig. 26).

It consisted of a vertical round shaft, $0.94 \times 0.87 \mathrm{~m}, 1.4 \mathrm{~m}$ deep, and one round chamber $3.3 \mathrm{~m}$ wide. The shaft was occupied in its lower part by a stepped ramp partly built with stones and partly made of compacted clay reaching the depth of $-1.4 \mathrm{~m}$. The passage to the chamber was $0.5 \mathrm{~m}$ wide, and also thanks to the ramp could be easily blocked by a flat stone. The latter was still standing in situ when the tomb was accidentally discovered, so that it was possible to observe it and how it blocked the passage. The stone was a big limestone slab $0.92 \mathrm{~m}$ long, $0.64 \mathrm{~m}$ wide, $0.18 \mathrm{~m}$ thick, fixed by means of two small limestone chops.

The round chamber had regular circular plan with a diameter of $3.3 \mathrm{~m}$ and a shallow slightly domed roof $0.95 \mathrm{~m}$ high (fig. 27). Along the north-western wall of the chamber, a platform was uncovered (Bench 33), made of flat stones, which hosted the latest inhumation ( $\S$ 3.2.7.) with some skull fragments and its funerary furnishings. Near the skull, between the head of the dead and the wall, an ovoid Middle Bronze IB jug (JD.16.T1/1) ${ }^{41}$ with painted decoration had been placed (fig. 28).

Some other long bones belonging to different individuals were found in the space surrounding the platform, and a shallow elongated niche, $0.95 \mathrm{~m}$ wide, had been cut along the southern wall of the chamber, perhaps for gaining space for one of them.

\subsubsection{Tomb 2}

Tomb 2 (figs. 27, 29) is to the north-west of Tomb 1 . This is the tomb more damaged by building activities in the compound. Bulldozer removed almost completely its roof and shaft, and also part of the underground chamber. It had a round shaft of $0.9 \mathrm{~m}$ of diameter, $1.3 \mathrm{~m}$ deep, only partially preserved to the north of the chamber. The burial cave, had a roughly circular shape, with a diameter of $1.8 \mathrm{~m}$, and a slightly concave floor. The roof was domed with a reconstructed height of $1.1 \mathrm{~m}$. A $0.32 \mathrm{~m}$ wide and $0.16 \mathrm{~m}$ high niche was cut in its southern wall. The dimensions and the presence of the niche suggest that Tomb 2 was originally excavated in the Early Bronze IV/Intermediate Bronze Age.

A Middle Bronze II dipper juglet with pinched rim, JD.12.T2/1 (fig. 28), ${ }^{42}$ was found in the shaft. It may signal the latest use of the tomb. No human neither animal remains were collected in Tomb 2.

41 Pritchard 1963, pl. 21:48. This jug with painted decoration, that can find some comparison at Tell elMutesellim (Loud 1948, pls. 11:18, 22; 12:21), suggests a possible date to the early phase of the Middle Bronze I (Gerstenblith 1980, 69; Nigro 2008, 379).

42 It can be compared with Kenyon 1965, fig. 121:5. 


\subsubsection{Tomb 3}

Tomb 3 was discovered to the north-west of Tomb 1 (fig. 24). It consisted of a round vertical shaft, $0.85 \mathrm{~m}$ of diameter and $1.6 \mathrm{~m}$ deep, and two chambers (1 and 2). Chamber 1 was located to the south-west of the shaft, and Chamber 2 is to the north of Chamber 1 (fig. 30).

The shaft was found filled up with stones of medium dimensions. Like in Tomb 1, also in Tomb 3 at the bottom of the shaft there was a stepped ramp facilitating the access to Chamber 1.

At the bottom of the shaft, the opening towards Chamber 1 was blocked by a closing stone: a big vertical limestone slab $1.5 \times 0.6 \mathrm{~m}$.

Chamber 1 has a circular plan with domed roof, $2.2 \mathrm{~m}$ of diameter and $0.8 \mathrm{~m}$ high. Its south-western quadrant is occupied by a raised stone platform (Bench 3), $1.4 \mathrm{~m}$ long on the east-west axis, and $1.1 \mathrm{~m}$ wide on the north-south one (fig. 31). The platform was coated with a whitish clayish plaster. Some fragmentary human vertebra (§ 3.2.7.) were still in situ on the platform at the moment of discovery. They had belonged to a dead buried on it. This individual was accompanied by a carinated bowl, JD.16.T3.3/1, ${ }^{43}$ and a jug with doublehandle, JD.16.T3.3/2, ${ }^{44}$ hinting at a drinking rite, common in such Middle Bronze Age tombs (fig. 32). ${ }^{45}$

Just to the north of the platform, a squared passage, $0.6 \mathrm{~m}$ wide, leads to Chamber 2. A $0.35 \mathrm{~m}$ high step marked the passage to this second round chamber, which up to now remained unexcavated.

\subsubsection{Tomb 4}

A fourth tomb was identified about $5 \mathrm{~m}$ east of Tomb 1 . It has a roughly round shaft, $1.06 \mathrm{~m}$ of diameter, filled up with a brownish sandy soil and limestone chops. Two blocks were uncovered within the shaft at $0.74 \mathrm{~m}$ from the surface, and they measure $0.50 \times 0.40$ $\mathrm{m}$. After the removal of these stones the excavation was interrupted.

\subsubsection{Tomb 5}

Tomb 5 (fig. 33) is the easternmost one identified so far (fig. 24), and it is provided by a shaft and a single chamber. It is smaller than the other tombs of the same necropolis. The shaft is roughly round, with a diameter of $1.10 \mathrm{~m}, 0.92 \mathrm{~m}$ deep, and it was filled up with a brownish layer (Filling 1). At its bottom some stones were sunken in the clayish soil, and the access to the chamber was blocked by a closing stone $0.5 \times 0.4 \mathrm{~m}$. The entrance to the tomb is $0.68 \mathrm{~m}$ high and $0.5 \mathrm{~m}$ wide (fig. 34). The chamber, to the north of the shaft, is round with a diameter of $1.6 \mathrm{~m}$, and it was filled up in its upper strata with a layer of debris (Filling 2) with limestone chops collapsed from the domed roof, and a few scattered pottery sherds. Under this upper deposit, there was a layer of buff sandy soil (Filling 3) accumulated against the eastern side of the chamber, aside a central L-shaped stone built

43 Pritchard 1963, fig. 50:20; Loffreda 1984, fig. 4:22. The type reminds bowls with high carination imitating metallic prototypes well known in the Levantine tradition (Nigro 2003a).

44 Pritchard 1963, pl. 21:48.

45 Garfinkel - Cohen 2007, 61; Zuckerman 2007, 189. 
platform (Bench 7) which hosted a fragmentary inhumation (Burial 5.1). Along eastern side of the chamber some pottery vessels were aligned (JD.T5.F.5), apparently as funerary set of Burial 5.1: a cooking jug with carinated body (JD.16.T5.5/1); a pinkish fabric jug (JD.16.T5.5/2, fig. 35), ${ }^{46}$ and another fragmentary jug (JD.16.T5.4/1; fig. 36), ${ }^{47}$ which was found on the L-shaped platform together with some teeth (four upper molars and two incisors) and scattered human bones comprising skull fragments (JD.16.T5.4.HR.1; § 3.2.7.), covered by two small flat stones. As the teeth and the jug show signs of having been burnt, it seems plausible that all these finds were the remains of an incineration. Burial 5.1 is thus likely to represent a sort of secondary internment dating back to early Iron Age, with the simple funerary set to the east (Filling 5), for which the bench was built overlaying previous layers. Under the bench, in facts, there was a brownish layer (Filling 6) with some fragmentary human bones (§ 3.2.7.). In this layer a copper dagger (JD.16.T5.1; fig. 37) was found, indicating the original presence of an earlier burial. This dagger belongs to a type spread in the Southern Levant during the Intermediate and Middle Bronze Ages, ${ }^{48}$ hinting, according its typology, to a use of Tomb 5 during these periods, as it is also documented by other tombs of the necropolis. The architecture of the tomb may suggest that it was first excavated in the Early Bronze IV/Intermediate Bronze Age.

\subsubsection{Tomb 6}

Tomb 6 (fig. 38) was identified roughly at middle of the small cemetery, north-west of Tomb 5 and south-east of Tomb 3. It has a large round shaft, $1.2 \mathrm{~m}$ of diameter, $1.4 \mathrm{~m}$ deep from the topsoil. It was filled up with a yellowish fine friable sandy soil (Filling 1), where an EB IVB globular jar with everted rim and flat base was found (JD.16.T6.1/1; fig. 39). ${ }^{49}$ The passage between the shaft and the chamber was blocked by a heap medium size stones. At the bottom of the shaft a small entrance, $0.6 \times 0.6 \mathrm{~m}$, gives access to a large chamber, $3.4 \times 4 \mathrm{~m}$ and $1.5 \mathrm{~m}$ high, to the west (fig. 40). Inside it, there was a thick layer of debris and collapsed stone chops (Filling 2). In this layer an almost complete human skeleton was found (§ 3.2.7.). At the moment of the opening of the tomb, a half skull, pierced on the frontal bone, left side over glabella, was next to the south-western wall. Under the debris layer, a yellowish clayish layer (Filling 3 ) was all over the chamber. Here, an ovoid jar with everted rim, combed decoration and flat base was found (JD.16.T6.3/1; fig. 39) ${ }^{50}$ along with scattered bones (§ 3.2.7.), in the western quadrant of the chamber. A rectangular limestone slab (Wall 4), $0.95 \times 0.5 \mathrm{~m}$, was standing next to the western wall of the chamber just underneath where the pierced half skull was uncovered. Removing Filling 3 a compacted chalky layer (Filling 5) was exposed, from where some fragmentary human bones were collected (§ 3.2.7.). Some human remains were also deposited under slab W.4.

The pottery found suggests a date to the Early Bronze IVB for the last use of the tomb.

46 Respectively, Arie 2006, fig. 13.59:8; Singer-Avitz 2002, fig. 9:1.

47 Mazar 2015, 16-17.

48 Maxwell-Hyslop 1946, 21; Dunand 1950-1958, 253, 292, 302, 383, figs. 277:9162, 415:1068, pls. LXII:9162, LXIV:9534, LXVIII:9662; Philip 1989, 103-104; Gernez 2007, 472-480, 482-486; Montanari 2014, 102-103.

49 It seems quite similar to necked jars with globular body and short flaring neck, Class NJ2, of D'Andrea (2014, vol. 2, 265).

50 It is comparable to Ovoid Storage Jar 1.2 class of D’Andrea (2014, vol. 2, 294-295, pl. CXVIII:2). 
3.2.7. Human and animal remains from Jebel Dhaher necropolis [A.G.]

This paragraph is devoted to a preliminary overview of human and animal remains collected in Tombs 1, 3, 5 and $6^{51}$ of the Jebel Dhaher necropolis (tab. 2). Most of the remains are human long bones and fragments of different kinds. Preservation status is not good, due to the high acidity of the soil inside tombs, which affected in many cases the outer cortex of bones. At a first autopsy, some long bones were totally abraded along the epiphysis and show on the outer surface small grooves.

\begin{tabular}{|c|c|c|}
\hline TOMB & HUMAN REMAINS & ANIMAL REMAINS \\
\hline Tomb 1 & $\begin{array}{l}\text { fragmentary long bones, } 2 \text { fragments of skull, } 2 \text { femura, } 2 \text { tibia, } 3 \\
\text { or } 4 \text { humerus, fragment of ribs (JD.16.T1.3.HR.1) }\end{array}$ & $\begin{array}{l}\text { fragmentary long bones } \\
\text { (JD.16.T1.3.FR.1) }\end{array}$ \\
\hline Tomb 2 & - & - \\
\hline Tomb 3 & vertebrae fragments (JD.16.T3.3.HR.1) & - \\
\hline Tomb 4 & - & - \\
\hline Tomb 5 & $\begin{array}{l}\text { F.4: } 3 \text { upper molars, fragment of a skull (JD.16.T5.4.HR.1); } \\
\text { F.5: fragmentary skull walls (JD.16.T5.5.HR.1), fragment of long } \\
\text { bones (tibia), } 2 \text { skull walls, } 1 \text { small incisor (JD.16.T5.5.HR.2); } \\
\text { F.6: } 1 \text { small incisor, } 1 \text { fragment of rib, fragmentary bones } \\
\text { (JD.16.T5.6.HR.1) }\end{array}$ & $\begin{array}{l}\text { ovicaprine astragalus } \\
\text { (JD.16.T5.4.FR.1) }\end{array}$ \\
\hline Tomb 6 & $\begin{array}{l}\text { F.2: } 1 \text { small incisor, } 1 \text { fragmentary rib, } 3 \text { fragmentary bones } \\
\text { (JD.16.T6.2.HR.1), } 1 \text { fragmentary skull, } 2 \text { shoulders, } 1 \text { ulna, } 1 \\
\text { radio, } 2 \text { femurs, fragmentary coccyx, } 1 \text { atlas, } 2 \text { vertebrae, } \\
\text { fragmentary long bones (JD.16.T6.2.HR.2); } \\
\text { F.3: } 2 \text { shoulders, } 1 \text { ulna, } 1 \text { radio, } 1 \text { fragment of basin, } 2 \text { tibia, } 2 \\
\text { fragmentary ribs, } 2 \text { vertebrae, fragmentary foot, fragmentary long } \\
\text { bones (JD.16.T6.3.HR.1); } \\
\text { F.5: } 2 \text { femurs, } 1 \text { humerus, } 1 \text { phalanx, a fragmentary mandible } \\
\text { (JD.16.T6.5.HR.1) }\end{array}$ & $\begin{array}{l}\text { fragmentary long bones } \\
\text { (JD.16.T6.2.FR.1) }\end{array}$ \\
\hline
\end{tabular}

Tab. 2 - Quantity and kind of human and animal remains collected in Jebel Dhaher necropolis during 2016 season.

In Tomb 1, both human and animal remains were found. Human bones include: two femura, two fragmentary tibia, and three or four humerus (JD.16.T1.3.HR.1; fig. 41). Moreover, between platform Bench 3, on which human remains were laid, and the wall of the chamber skulls fragments were found (a parietal bone and a frontal bone). Skeletal remains on the platform seem to be related to a primary crouched inhumations (Burial 1.1). According to the number of long bones lying on platform, it is reasonable that this tomb was a multiple burial.

In Tomb 3, it was possible to recognized some human vertebrae (JD.16.T3.3.HR.1; fig. 42) on the built up stone platform, JD.T3.B.3.

In Tomb 5, some fragments of a skull and three burnt upper molars (JD.16.T5.4.HR.1), together with an ovis vel capra astragalus (JD.16.T5.4.FR.1) were found in Filling 4, in an incineration (Burial 5.1) inside juglet JD.16.T5.4/1 (fig. 36). Moreover, in Filling 5, other fragments of human skull (JD.16.T5.5.HR.1), an incisive and fragments of long bones (probably a tibia; JD.16.T5.5.HR.2) were retrieved. Near the dagger, in Filling 6 under the L-shaped platform, a tooth was collected, a small incisor, together with a fragment of rib

51 These are currently the only tombs with recognizable remains. 
and other small bone fragments (JD.16.T5.6.HR.1), belonging to an earlier inhumation (Burial 5.2).

Bones from Tomb 6 were characterized by clear calcareous concretions which in some cases have contributed to their welding. This is the case of an ulna and radio in T6.F.3, completely welded together with a concretion in the middle, probably residue of tibial plate of a sub-adult placed above. Bones were extremely fragile and in the case of the long bones showed small grooves on the epiphysis, attributable also to corrosion suffered in the soil.

Nevertheless, it was possible to recognize some important skeletal sections, as it is in the case of human remains found in Filling 2 (fig. 43). A small fragmentary skull, probably belonging to a young woman (Burial 6.1), without glabella, with rounded orbits and small and pointed mastoid process was recognized. According to teeth still in place in the mandible two premolars and three molars, it can be assumed that the individual had died when it was 20 years old. In the mandible there is a hole, perhaps the residual of an alveolar infection.

Basically, two burials can be distinguished in Tomb 6: one (Burial 6.1) on the limestone slab W.4 laying to the west of the tomb; the other (Burial 6.2) to the east of the slab and under it, in Filling 5 (a male adult aged 20).

The presence of other sparse bones shows that the tomb served for multiple burials during a certain time lapse during the Early Bronze Age.

\section{3. el-Atan Tomb (n. 030 in fig. 3)}

An Early Bronze IVB tomb was discovered on early June 2009 due to the erection of a private house in el-Atan Street, nearby the Milk Grotto, ${ }^{52} 400 \mathrm{~m}$ east of the Nativity Church, in the area of the city known as Tell Bethlehem, in a land owned by Mr. Nassri elBandaq.

The shaft single chamber tomb was incidentally discovered by a bulldozer which cut through a part of the burial chamber. The archaeologists thus entered it directly from the chamber and they could not excavate the shaft, which was in the land of another owner, who did not allow them to operate.

On $19^{\text {th }}$ June 2009 the MOTA-DACH Office of Bethlehem started rescue excavations, collecting some human remains and a funerary set comprising 4 four-spouted lamps, 5 slightly carinated bowls with combed or grooved decoration under the rim, ${ }^{53} 1$ flat base ovoid jar with flaring neck and combed decoration, ${ }^{54} 1$ flat base jar with upper wall slightly waisted with combed and wavy combed decoration, ${ }^{55} 2$ amphoriskoi with combed

52 In 1989 a rock-cut tomb used between the $8^{\text {th }}$ and the $1^{\text {st }}$ century BC was discovered in the site of Ain el-Atan, in the neighborhood of Bethlehem (Dadon 1990; 1997), at about $2.5 \mathrm{~km}$ to the south-west of the centre of Bethlehem, in a site identified with Khirbet el-Khokh.

53 Kenyon 1965, 43-44, fig. 21:2-3.

54 Nigro 2003b, fig. 24:1.

55 Kenyon - Holland 1982, fig. 94:10; Nigro 2003b, fig. 20:5. 
decoration ${ }^{56}$ and a beaker, as well as a copper pin with rolled head, ${ }^{57}$ and 5 carnelian beads. This material dates back to the second part of the Early Bronze IV (fig. 44). ${ }^{58}$

This tomb is included into the already known cemetery extended to the east and to the south of the Nativity Church, in use from the Early Bronze Age until the Byzantine Period. ${ }^{59}$

\subsection{Necropolis of Bardhaa (n. 029 in fig. 3)}

A necropolis in the village of Bardhaa, to the east of Khalet al-Jam'a and $2.5 \mathrm{~km}$ southeast of the Nativity Church, was discovered and looted in the period between 1967 and 1995 (fig. 45). ${ }^{60}$ The Necropolis of Bardhaa was set on the northern flank of Wadi Ta'amireh and to the west of Wadi et-Tin, along emerging limestone bedrock cliffs. Tombs are mostly shaft tombs, with squared or round shafts, leading to underground rock-cut chambers. A preliminary visit to the site showed that it had been largely plundered, and a provisional calculation of the number of tombs is around 30-40 tombs.

Information provided by the Palestinian Tourism Police, which sequestered materials by antique dealers during some building activities at the site, allowed to rescue some pottery vessels, including two Middle Bronze ovoid jars, BL1518 and BL1536, ${ }^{61}$ which confirm the chronological range of the necropolis between the Early Bronze IV and Middle Bronze I-II (fig. 46).

The Necropolis of Bardhaa seems to belong to a system of cemeteries established on the emerging bedrock spurs of the hills in between Wadi 'Artas, Wadi Ta'amireh and Wadi etTin south of Bethlehem up to Tekoa: ${ }^{62}$ Khalet al-Jam'a, Jebel Dhaher, Bardhaa, during the urban occupation of Bethlehem in the Bronze and Iron Ages. They were first established in the Early Bronze Age and one may suggest that each of these cemeteries belonged to a familiar group, a clan or a tribe.

\section{OTHER ARCHAEOLOGICAL SITES}

\subsection{Khirbet el-Kôm (n. 018 in fig. 2)}

The site ${ }^{63}$ that lays along Wadi es-Saffar, a tributary of Nahar ed-Duweir, is about 11.2 Km west of Hebron and $11.6 \mathrm{Km}$ east of Tell ed-Duweir/ancient Lachish. ${ }^{64}$ It was put on

56 Kenyon - Holland 1982, fig. 98:19.

57 Gernez 2008, 247-248, pl. 11.

58 Pottery equipment of el-Atan Tomb, together with the pin with rolled head (Gernez 2008, 260, fig. 8), aligns itself with the horizon of Southern Palestine (Amiran 1969, 80-82, pl. 22; Dever 1980, 48; fig. 4; D'Andrea 2014, vol. 1, 201, fig. 5:32, vol. 2, 91-118, pl. XXX) in late Early Bronze IV.

59 Bagatti 1952, 261-262; Saller 1963, 325; 1964, 287; 1968; Gutman - Berma 1970, 585; Prag 2000, 177 , fig. 3.

60 In the area of Bardhaa some structures, interpreted as a Roman house, an enclosure wall and a mosaic pavement, were discovered on September 1944 (www.iaa-archives.org.il/zoom/zoom.aspx?folder_id=2319\&type_id=\&id=35263).

61 They can find a parallel in necropolis of Jericho (Kenyon 1960, fig. 182:2-3) and Tell Beit Mirsim (Ben-Arieh 2004, fig. 2.15.76-77).

62 Vincent 1947; Dajani 1960, 102. Moreover, Saller (1964, 288) quotes the presence of rock-cut tombs eastwards and northwards of Tekoa.

63 A special thank goes to Dr. Ahmed Rjoob that made possible the visit to Khirbet el-Kôm and Jebel Qa'aqir, and guided the team sharing his knowledge and experience about these sites and beyond.

64 The site has been tentatively identified with Biblical Saphir (Micah 1:11). 
the map by Captain C.R. Conder and Captain H.H. Kitchener, who described it as a large ruin, ${ }^{65}$ and successively partially sounded during the Spring 1971 by J.S. Holladay on behalf of the University of Toronto, Canada. ${ }^{66}$ The site was first occupied during the Chalcolithic Period, albeit in a very limited way, and stably settled during the Early Bronze Age. Some small finds, pottery vases and sparse structures of this phase were uncovered. ${ }^{67}$ A more substantial occupation characterizes the life of settlement from the Iron Age onwards, which, in the University of Toronto excavations, was found directly upon Early Bronze Age collapsed remains. According to the collected material, Khirbet el-Kôm was settled in the $10^{\text {th }}$ century BC being reconstructed several times until the Persian and Hellenistic periods. During Iron Age II, Khirbet el-Kôm was a fortified site on the road from Hebron to Lachish in the Kingdom of Judah. The remains of its monumental defensive system, consisting of heavy stone walls, probably of the casemate type with a city-gate, are still visible, in the later reconstruction of the Hasmoneans. ${ }^{68}$

One of the major small finds collected on the site is a bilingual, Aramaic and Greek, ostracon dated to the late $4^{\text {th }}$-early $3^{\text {rd }}$ century BC, ${ }^{69}$ concerning an early loan of money (32 drachma), beyond other ostraca in Aramaic and Greek. ${ }^{70}$

Ancient fortification walls underlay the modern terrace wall of the village that nowadays encircles the site (fig. 47); the area all around the city-walls is terraced for cultivation, with olive tree groves. Modern buildings are unfortunately threatening the ancient structures having been built inside and upon the terrace walls.

\subsection{Abar al-Nabi Daoud - David's Wells (n. 017 in fig. 3)}

The so-called David's Wells (Abar [Beyar] al-Nabi Daoud) are an historical archaeological site in Bethlehem Downtown, inside the yard of the Franciscan Fathers Catholic Action Circle, in King David Street (fig. 48), where the tradition identified one of the many holy places of the town. ${ }^{71}$ They consist of three large cisterns hewn in the northern rock hill (Ras Eftais), located at the entrance of the old main road of the city. ${ }^{72}$

According to the guardian of the Catholic Action Circle, the wells opening on the cisterns were actually five, but only three of them are still visible inside the compound of this institution, while the other two are northwards, outside the boundary wall of the Circle, buried under the modern street. ${ }^{73}$ The real situation was clarified by Father Bellarmino Bagatti o.f.m. when he reported that three wells opening on one underground cistern are in Franciscan Father's land, while a second cistern (with two wells) was located north of the street, in the nearby Greek Orthodox Church property.

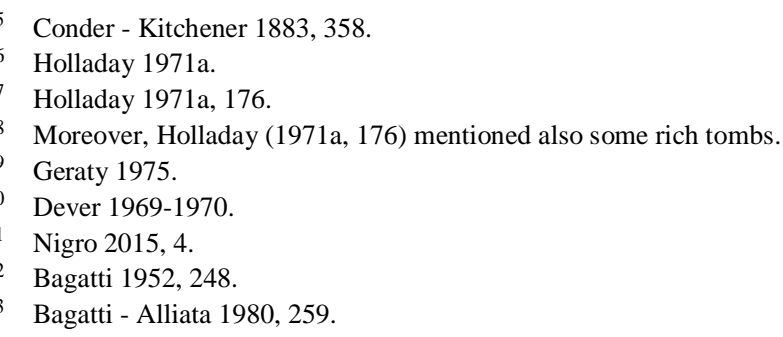


What seems noteworthy is that until the 50ies of the last century these cisterns represented the main source of fresh water for inhabitants of Bethlehem, being located on a top-hill, connected to the Roman aqueduct. Nowadays, only the southernmost one is still operating.

In addition to the wells, a cemetery and remains of a Byzantine church (Saint Cassian or Saint Serge) east of them, believed built by Emperor Justinian, were discovered in the same site. ${ }^{74}$

The cemetery, including underground galleries with arcosolia, each containing some sepulchral pits (interpreted at the moment of discovery as the David's sepulchre!), was discovered on June 1935 and restored in 1962 by Br. Michelangelo Tizzani. ${ }^{75}$ During excavations, some pottery dating back to the $4^{\text {th }}$ century $\mathrm{AD}$ was collected and some contemporary graffiti were uncovered, among these a Constantine cross.

In 1895, part of the mosaic floor of the church bearing an inscription with verses 19 and 20 of Psalm 117 ( «Open to me the gates of justice; I will enter them and give thanks to the Lord. This gate is the Lord's, the just shall enter it») was discovered. ${ }^{76}$

The preservation of this site, which has characterized for many centuries the history of Bethlehem, is a goal of the MOTA-DACH, which has now collected plans and pictures of both cisterns and wells.

\section{FINAL REMARKS}

The second season of joint archaeological investigations and protection of sites in the urban area of Bethlehem has been very fruitful and it has provided a large amount of scientific data, to be included as just recovered tesserae belonging to the beautiful mosaic of the history of this renowned ancient town of Palestine. New data corroborate previous reconstructions and raise new questions for scholars to be answered.

The quick publication of this unfortunately sparse pieces of evidence, in spite of its unavoidable preliminary nature, is the only way to fix the memory of monuments, finds and other archaeological and landscape information, before the hurried development of the town sweeps them definitely out.

The joint commitment for the protection of antiquities of the MOTA-DACH and Sapienza University of Rome allowed to survey, document and recover tombs, structures and items which were threatened by modern building activities and illegal trade of antiquities. Each single rescued pottery vessel or simple archaeological item is a piece of the history of Palestine which is given back to collective memory as part of Humankind's shared Heritage.

74 Bagatti 1952, 248-255; 1968, fig. 32.

75 Bagatti 1968, 225. Also the area to the west of the wells, nowadays corresponding to St. Joseph Street and St. Joseph Church, in the land of the Sisters of Saint Joseph of the Apparition, an area also called Baten, was occupied by tombs during Roman and Byzantine periods, suggesting that this quarter of the modern Bethlehem was unsettled in antiquity during those phases (Saller 1964, 287; Bagatti 1952, 255; 1968, 237).

76 Lagrange 1895, 625-626; Séjourné 1895, 439-444.

77 Hussein - Al-Houdalieh - Tawafsha 2017. 


\section{REFERENCES}

ACSÁDI, G. - NEMESKÉRI, J.

$1970 \quad$ History of Human Life, Span and Mortality (Akadémiai Kiadó), Budapest 1970.

ALBRIGHT, W.F.

1932 The Excavation of Tell Beit Mirsim. Vol. I: The Pottery of the First Three Campaigns (1930 - 1931) (Annual of American School of Oriental Research 12), New Heaven 1932.

AMIRAN, R.

1969 Ancient Pottery of the Holy Land, From the Prehistoric to the Persian Period, Jerusalem 1969.

ARIE, E.

2006 Chapter 13. The Iron Age I Pottery: Levels K-5 and K-4 and an Intra-site Spatial Analysis of the Pottery from Stratum VIA: I. FinKELSTEIN - D. UsSISHKIN - B. HALPERN (eds.), Megiddo IV. The 1998 - 2002 Seasons (Monograph Series 24), Tel Aviv 2006, pp. 191298.

BAGATTI, B. O.F.M.

1952 Gli antichi edifici sacri di Betlemme in seguito agli scavi e restauri praticati dalla Custodia di Terra Santa (1948-51) (Studium Biblicum Franciscanum Collectio Maior 9), Gerusalemme 1952.

1968 Recenti scavi a Betlemme (Grotte di S. Girolamo; cisterne di David): Liber Annuus 18 (1968), pp. 181-237.

Bagatti, B. - Alliata, E.

1980 Scavo ai “Pozzi di Davide” a Betlemme: Liber Annuus 30 (1980), pp. 259-262.

BARUKH, Y. - SHORUKH, I.

1998 Khirbet Beit Bassa: Hadashot Arkheologiyot/Exploration and Survey in Israel 18 (1998), p. 98.

2006 Building of the Persian, Hellenistic and Early Roman Periods at Khirbat Kabar, in the BEN-ARIEH, S. Northern Hebron Hills: ‘Atiqot 52 (2006), pp. 49-71*.

2004 Bronze and Iron Age tombs at Tell Beit Mirsim (Israel Antiquity Authority 23), Jerusalem 2004.

BIETAK, M. (ed.)

2000 The Synchronisation of Civilisations in the Eastern Mediterranean in the Second Millennium B.C. Proceedings of an International Symposium at Schloß Haindorf, 15th17th of November 1996, and at the Austrian Academy, Vienna, 11th-12th of May 1998 (Österreichischen Akademie der Wissenschaften XIX. Contributions to the Chronology of the Eastern Mediterranean 1), Wien 2000.

2003 The Synchronisation of Civilisations in the Eastern Mediterranean in the Second Millennium B.C. II. Proceedings of the SCIEM 2000 - EuroConference, Haindorf, 2nd of May - 7th of May 2001 (Österreichischen Akademie der Wissenschaften XXIX. Contributions to the Chronology of the Eastern Mediterranean 4), Wien 2003.

BIETAK, M. - CZERNY, E. (eds.)

2002 The Middle Bronze Age in the Levant. Proceedings of an International Conference on MB IIA Ceramic Material, Vienna, 24th-26th of January 2001 (Österreichischen Akademie der Wissenschaften XXVI. Contributions to the Chronology of the Eastern Mediterranean 3), Wien 2002.

2007 The Synchronisation of Civilisations in the Eastern Mediterranean in the Second Millennium B.C. Proceedings of the SCIEM 2000 - 2nd EuroConference, Vienna, 28th of 
May - 1st of June 2003 (Österreichischen Akademie der Wissenschaften XXXVII. Contributions to the Chronology of the Eastern Mediterranean 9), Wien 2007.

CANCI, A. - MinOZZI, S.

2005 Archeologia dei resti umani, Roma 2005.

CleRmont-GanNEAU, C.S.

1899 Archaeological Researches in Palestine 1873-1874 (Palestine Exploration Fund), London 1899.

CONDER, C.R. - KITCHENER, H.H.

1883 The Survey of Western Palestine. Vol. III: Judaea (Palestine Exploration Fund), London 1883.

CREE, F. DE

1999 History and Archaeology of Bēt Sāiür Region. A Preparatory Study for a Regional Survey (The Bethlehem Archaeological Project): Zeitschrift des Deutschen Palästina-Vereins 115

DADON, $\mathrm{M}$. (1999), pp. 59-84.

1990 El-‘Aýn (Bethlehem): Excavation and Surveys in Israel 9 (1990), pp. 156-157.

1997 A Burial Cave of the Middle Bronze Age I at Giv'at Ze'ev: ‘Atiqot 32 (1997), pp. 51, 199-201*.

DAGAN, Y.

2006 Map of Amazya (109). Volume I, The Northern Sector (Archaeological Survey of Israel. DAJANI, A.K. Israel Antiquities Authority), Jerusalem 2006.

1960 Middle Bronze Age pottery: Annual of the Department of Antiquities of Jordan IV-V D'ANDREA, M. (1960), pp. 99-113.

2014 The Southern Levant in Early Bronze IV. Issues and perspectives in the pottery evidence (Contributi e Materiali di Archeologia Orientale XVII), Roma 2014.

DEVER, W.G.

1969-1970 Iron Age Epigraphic Material from the Area of Khirbet el-Kôm: Hebrew Union College Annual 40-41 (1969-1970), pp. 139-204.

1975 A Middle Bronze I Cemetery at Khirbet el-Khirmil: Eretz Israel 12 (1975), pp. 18-33.

1980 New Vistas on the EB IV ("MB I") Horizon in Syria-Palestine: Bulletin of the American School of Oriental Research 237 (1980), pp. 35-64.

1981 Cave G26 at Jebel Qa'qir: A domestic Assemblage of Middle Bronze I: Eretz Israel 15 (1981), pp. 22-32.

2014 Excavations at the Early Bronze IV Sites of Jebel Qa'qair and Be'er Resisim (Studies in DUNAND, M. the Archaeology and History of the Levant 6), Winona Lake 2014.

1950-1958 Fouilles de Byblos. Tome II. 1933-1938, Paris 1950-1958.

ESCOBAR, J.

1976 Estudio de los restos Arqueologicos de Tecoa: Liber Annuus 26 (1976), pp. 5-26.

GARFINKEL, Y. - COHEN, S.

2007 The Early Middle Bronze Cemetery of Gesher. Final Excavation Report (Annual of American School of Oriental Research 62), Boston 2007.

GARSTANG, J.

1933 Jericho: City and Necropolis: Liverpool Annals of Archaeology and Anthropology XX (1933), 3-42. 
GERATY, L.T.

1975 The Khirbet el-Kôm Bilingual Ostracon: Bulletin of American School of Oriental GERNEZ, G. Research 220 (1975), pp. 55-61.

2007 L'armement en métal au Proche et Moyen-Orient Des origines à 1750 av. J.-C., Paris 2007.

2008 Le métal de Tell Arqa a l'âge du Bronze: Bulletin d'Archéologie et d'Architecture Libanaises 12 (2008), pp. 221-264.

GERSTENBLITH, P.

1980 A Reassessment of the Beginning of the Middle Bronze Age in Syria-Palestine: Bulletin of America School of Oriental Research 237 (1980), pp. 65-84.

GITIN, S.

1975 Middle Bronze I "Domestic Pottery” at Jebel Qa‘aqir: a Ceramic Inventory of Cave G 23: Eretz Israel 12 (1975), pp. 46-62.

GUTMAN, S. - BERMAN, A.

$1970 \quad$ Bethléem: Revue Biblique 77 (1970), pp. 583-585.

HALAYQA, I.K.H.

2015 Two Canaanite Scarabs from Kherbit el-Jami` (el-‘Ubayat) South of Bethlehem: UgaritForshungen 46 (2015), pp. 183-188.

HARVEY, W.

1937 Bethlehem, Nativity Church: Archaeologia 87 (1937), pp. 7-17.

HENNESSY, J.B.

1966 An Early Bronze Age Tomb Group from Beth Sahur: Annual of Department of Antiquities HERR, L.G. of Jordan XI (1966), pp. 19-40.

1986 A Seventh Century B.C. Tomb Group from Tekoa: L.T. GerATY - L.G. HeRR (eds.), The Archaeology of Jordan and Other Studies (Andrews University Seminary Studies), Berrien Springs 1986, pp. 265-284.

HERZOG, Z. - SINGER-AvITZ, L.

2015 Chapter 2.4: Iron Age IIA-B: Judah and the Negev: S. GITIN (ed.), The Ancient Pottery of Israel and its Neighbors, from the Iron Age through the Hellenistic Period (Israel Exploration Society), Jerusalem 2015, pp. 213-255.

HIZMI, H. - SHABTAI, Z.

1997 Khirbet en-Najjar in Beit Jala: ‘Atiqot 32 (1997), pp. 57-61.

HOLLADAY, J.S.

1971a Khirbet el-Qôm: Israel Exploration Journal 21 (1971), pp.175-177.

1971b Khirbet el-Kom: Revue Biblique 78 (1971), pp. 593-595.

Hussein, S. - Al-Houdalieh, A. - TAWAFSHa, S.A.

2017 The Destruction of Archaeological Resources in the Palestinian Territories, Area C: Kafr KENYON, K.M. Shiyān as a Case Study: Near Eastern Archaeology 8.1 (2017), pp. 40-49.

1960 Excavations at Jericho. Volume One. The Tombs excavated in 1952-1954, London 1960.

1965 Excavations at Jericho. Volume Two. The Tombs Excavated in 1955-1958, London 1965.

KenYon, K.M. - Holland, T.A.

1982 Excavations at Jericho. Volume Four. The Pottery Type Series and Other Finds, London 1982.

LAGRANGE, P.M.J.

1895 Chronique de Jérusalem (fouilles de M. Bliss, voyage de Bliss au pays de Moab, nouvelles de Bethléem): Revue Biblique 4 (1895), pp. 622-626. 
LEVENTAL, S.

2010 Battir Spring Rehabilitation: The Battir Spring - the Road to a Safe Water Resource (Tufts University Department of Urban and Environmental Policy, Water Resources Policy and Watershed Management), Boston 2010.

LOFFREDA, S.

1984 La tomba n. 4 del Bronzo Medio II B a Betania: Liber Annuus 34 (1984), pp. 357-370.

LONDON, G.A.

1985 Decoding Designs: The Late Third Millennium B.C. Pottery From Jebel Qa'aqir, PhD

LOUD, G.

1948 Megiddo II. Season of 1935-1939 (Oriental Institute Publications 62), Chicago 1948.

MAGNESS, J.

2003 The Archaeology of the Early Islamic Settlement in Palestine, Winona Lake 2003.

MAXWELL-HYSLOP, K.R.

1946 Daggers and Swords in Western Asia. A Study from Prehistoric Times to 600 B.C.: Iraq 8

MAYS, S.

2010 The Archaeology of Human Bones, London 2010².

MAZAR, A.

2015 Iron Age I: Northern Coastal Plain, Galilee, Samaria, Jezreel Valley, Judah, and Negev: S. Gitin (ed.), The Ancient Pottery of Israel and its Neighbors, from the Iron Age through the Hellenistic Period (Israel Exploration Society), Jerusalem 2015, pp. 5-70. MONTANARI, D.

2014 An EB IV dagger from Tell es-Sultan/Jericho: Vicino Oriente XVIII (2014), pp. 101-111. MURPHY-O’CONNOR, J.

1998 The Holy Land: An Oxford Archaeological Guide from Earliest Times to 1700, 4th NigRo, L. Edition (Oxford University Press), Oxford 1998.

2003a The Smith and the King of Ebla. Tell el Yahudiyeh Ware, Metallic Wares and the Ceramic Chronology of Middle Bronze Syria: M. BIETAK (ed.), The Synchronisation of Civilisations in the Eastern Mediterranean in the Second Millennium B.C. II. Proceedings of the SCIEM 2000 - EuroConference, Haindorf, 2nd of May - 7th of May 2001 (Österreichischen Akademie der Wissenschaften XXIX. Contributions to the Chronology of the Eastern Mediterranean 4), Wien 2003, pp. 345-363.

2003b Tell es-Sultan in the Early Bronze Age IV (2300-2000 BC). Settlement VS Necropolis - A Stratigraphic Periodization: Contributi e Materiali di Archeologia Orientale 9 (2003), pp. 121-158.

2008 Towards a Unified Chronology of Syria and Palestine. The Beginning of the Middle Bronze Age: P. Matthiae - F. Pinnock - L. Nigro - L. Peyronel (eds.): Proceedings of the International Colloquium From Relative Chronology to Absolute Chronology: the Second Millennium BC in Syria-Palestine (Rome, 29th November - 1st December 2001) (Contributi del Centro Linceo Interdisciplinare «Beniamino Segre» 117), Roma 2008, pp. 365-389.

2015 Bethlehem in the Bronze and Iron Age. A Summary in the light of recent discoveries by The Palestinian MOTA-DACH: Vicino Oriente XIX (2015), pp. 1-15.

Nigro, L. - MontAnARI, D. - GHAYyadA, M. - YAsine, J.

2015 Khalet al-Jam'a. A Middle Bronze and Iron Age necropolis near Bethlehem (Palestine): Vicino Oriente XIX (2015), pp. 185-218. 


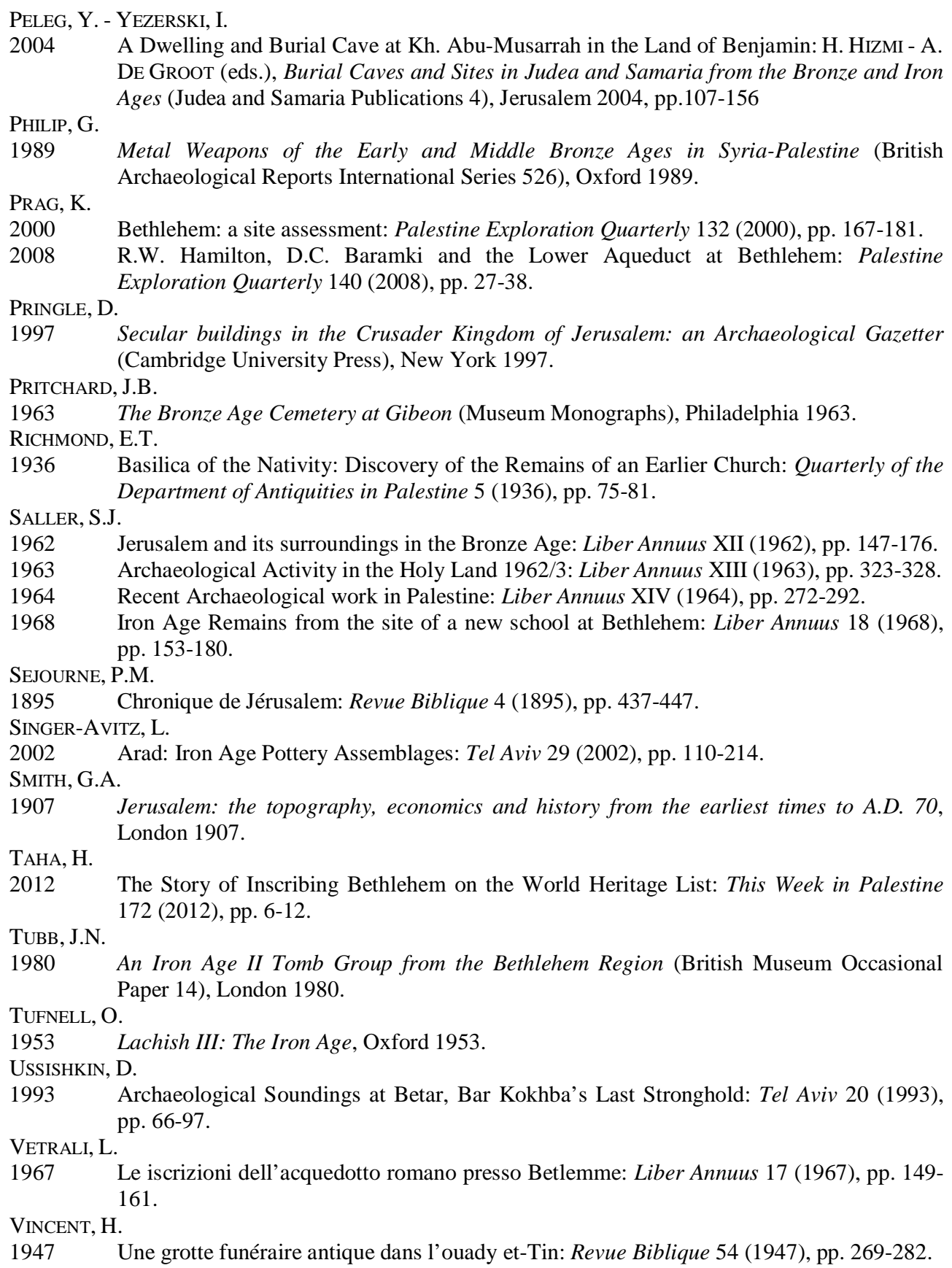


VINCENT, H. - ABEL, F.-M.

1914 Bethléem. Le Sanctuaire de la Nativité, Paris 1914.

YEZERSKI, I.

1997 Burial Caves in the Hebron Hills: 'Atiqot 32 (1997), pp. 21-36*.

2004 An Iron Age II Burial Cave at Rās āl-Tawīl: H. Hizmi - A. DE Groot (eds.), Burial Caves and Sites in Judea and Samaria from the Bronze and Iron Ages (Judea and Samaria ZUCKERMAN, S Publications 4), Jerusalem 2004, pp. 209-230.

2007 '..Slaying oxen and killing sheep, eating flesh and drinking wine..': feasting in Late Bronze Age Hazor: Palestine Exploration Quarterly 139 (2007), pp. 186-204. 


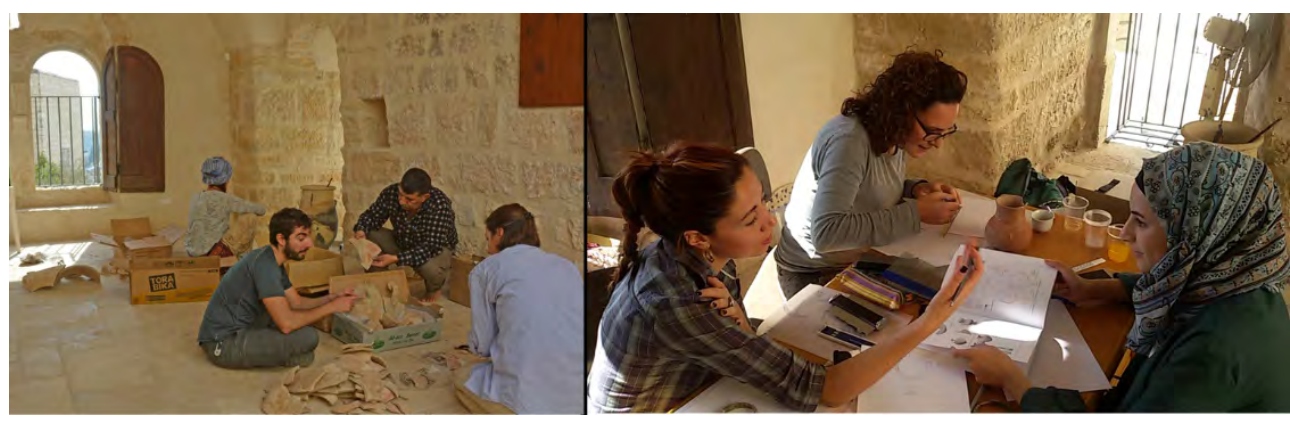

Fig. 1 - The Italian-Palestinian team during the expedition in Autumn 2016 in the Expedition Headquarter at Al-Badd Giacaman Museum in Bethlehem.

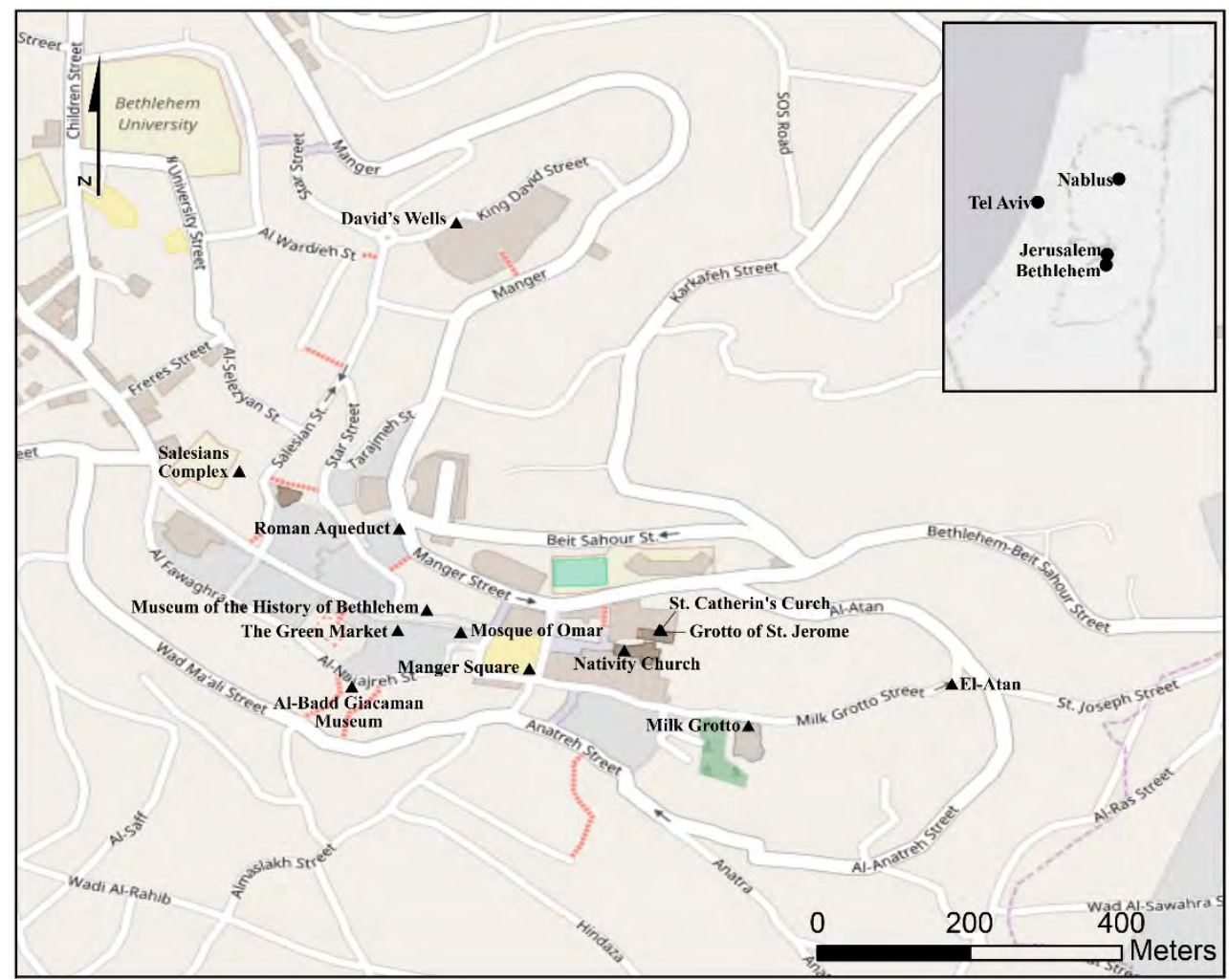

Fig. 2 - Comprehensive archaeological and historical map of the city of Bethlehem developed by Sapienza Expedition - MOTA-DACH. 


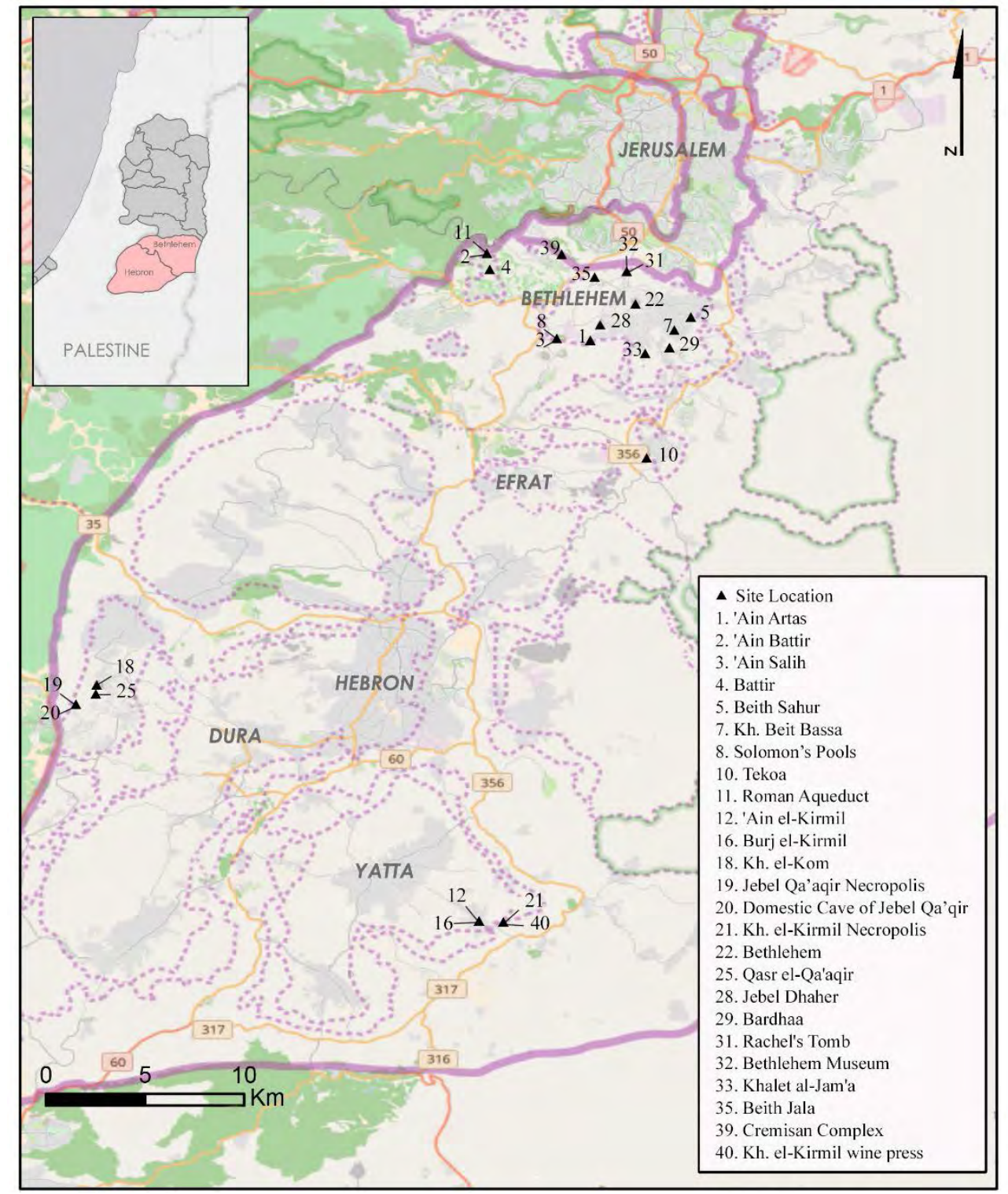

Fig. 3 - Comprehensive map of the area of Bethlehem, city and surroundings, and of neighbouring archaeological sites, developed by Sapienza Expedition - MOTA-DACH. 


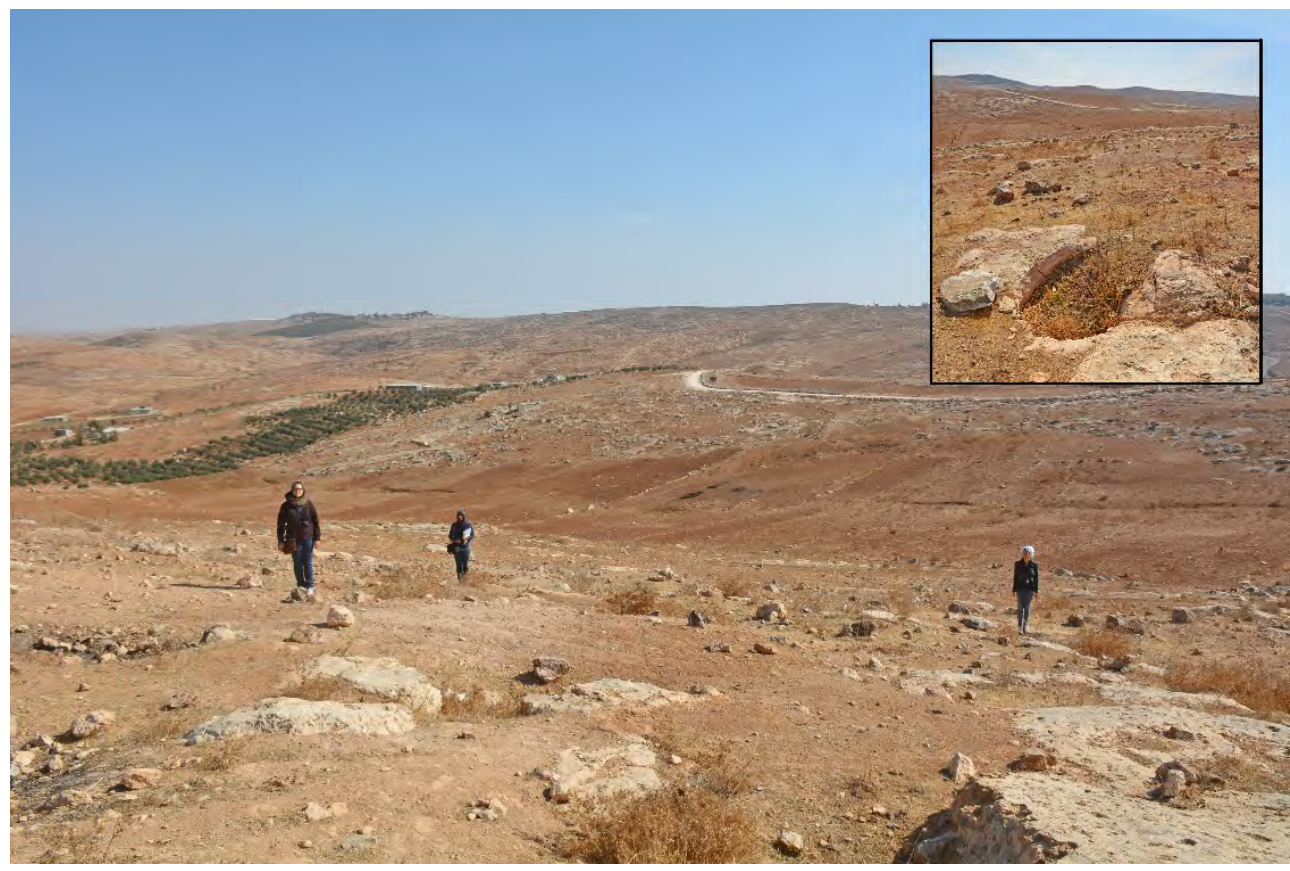

Fig. 4 - Necropolis of Khirbet el-Karmil, from north-west.

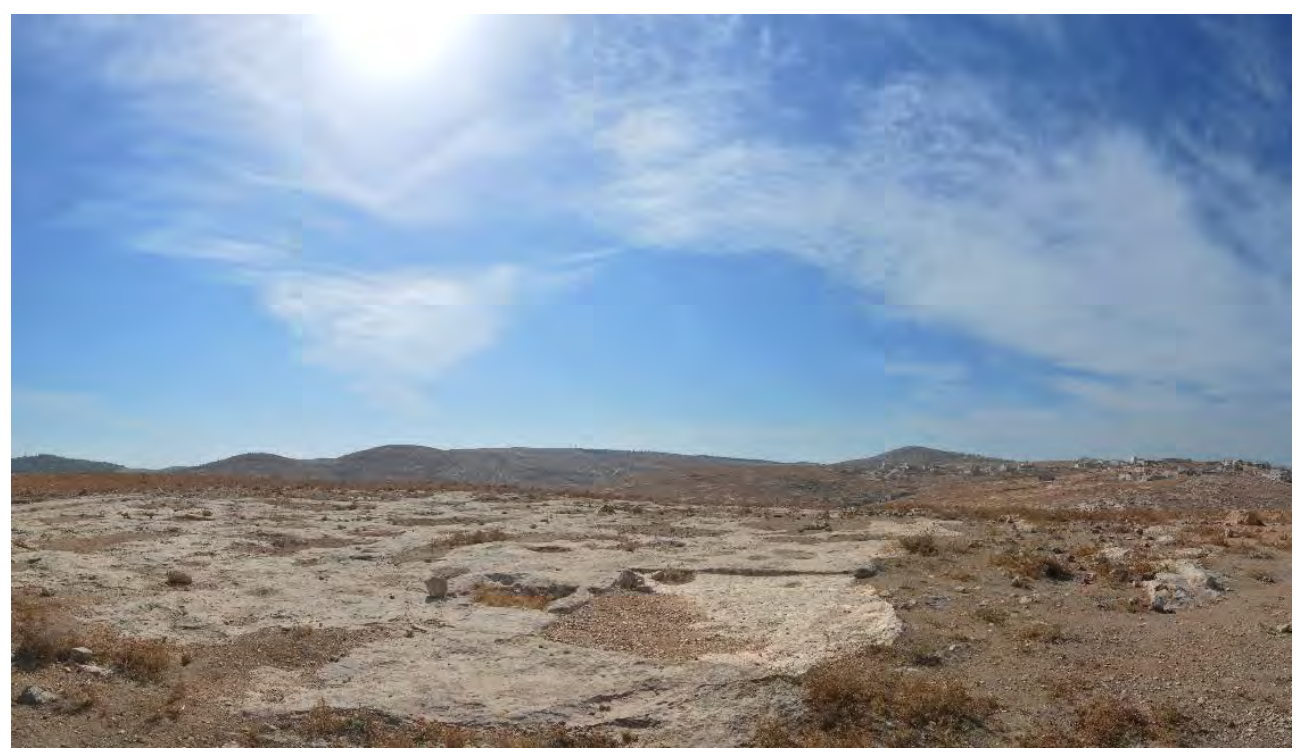

Fig. 5 - Khirbet el-Karmil wine press, from north-east. 

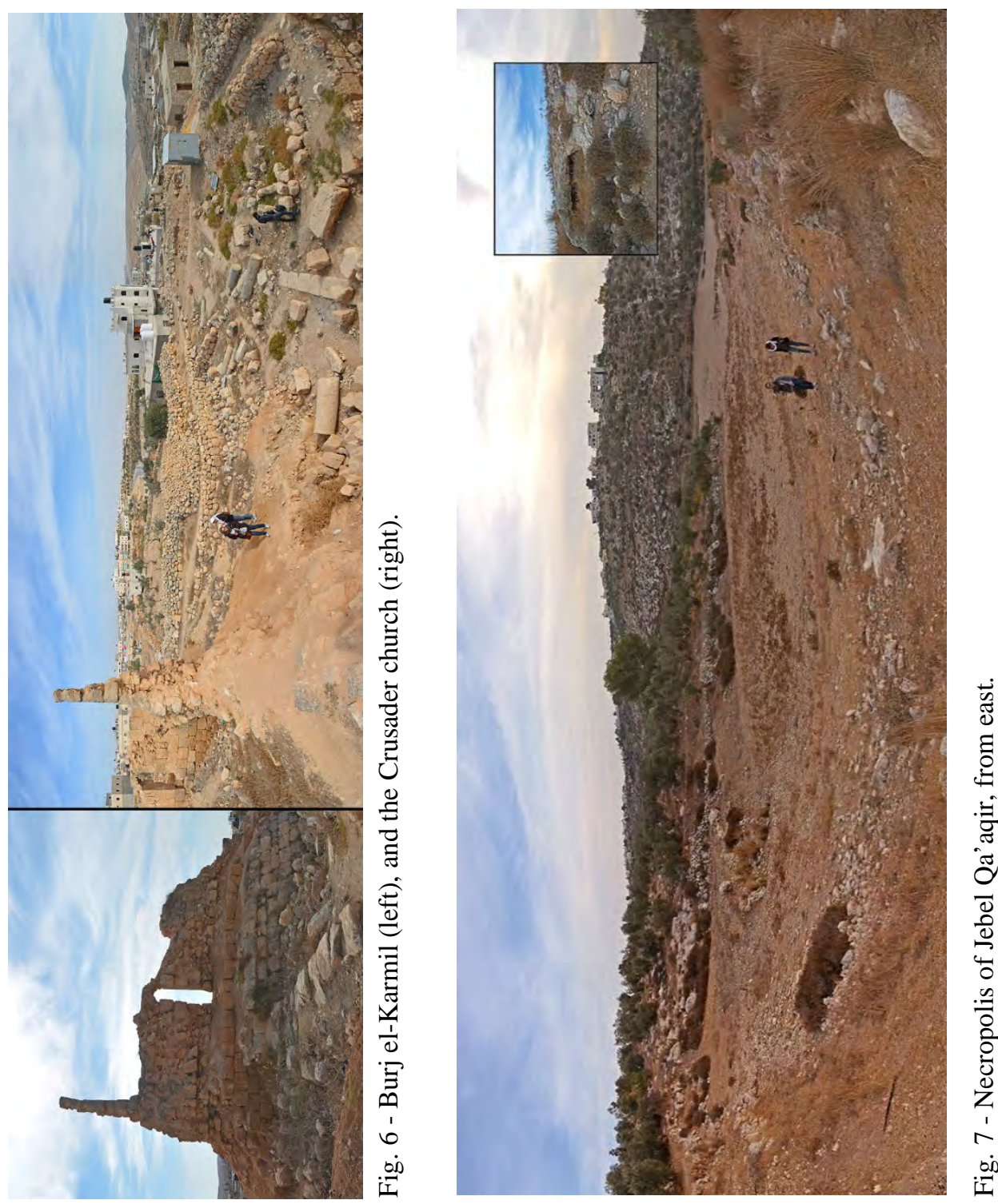


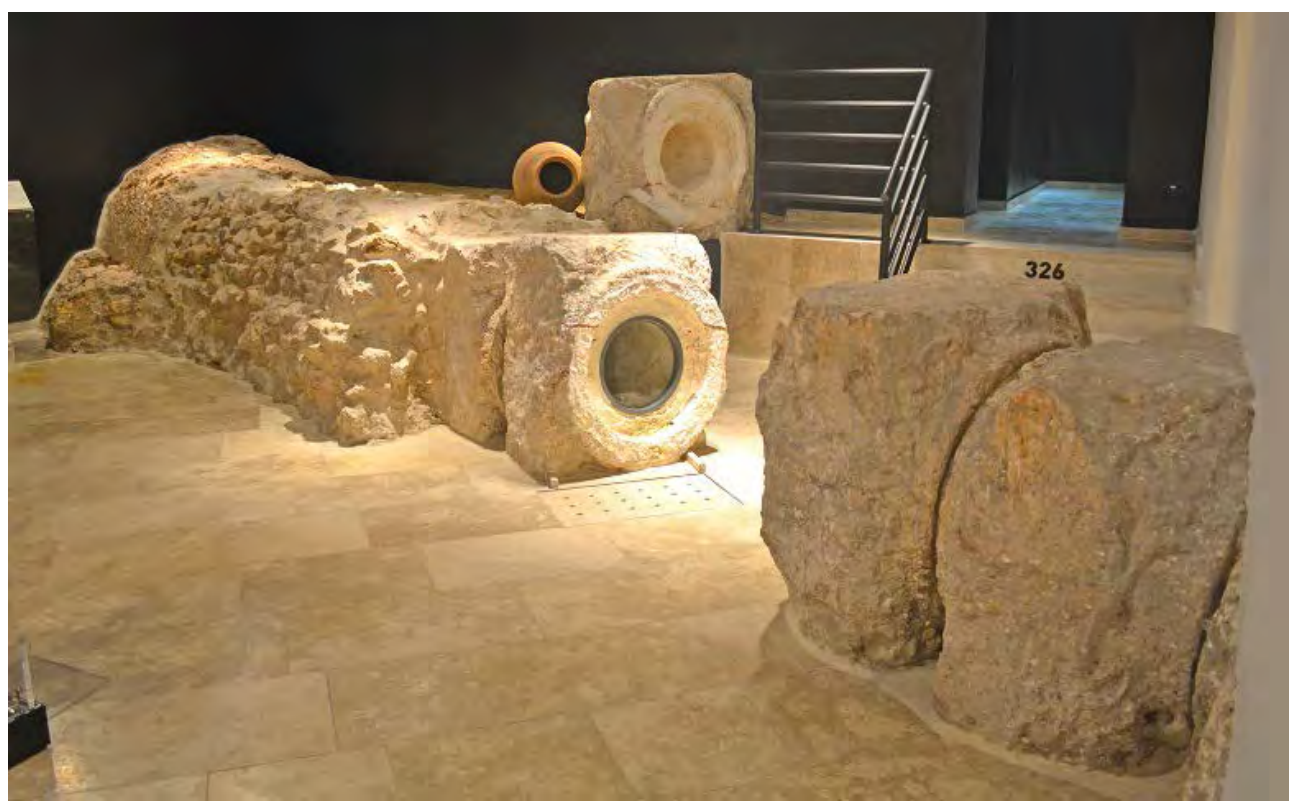

Fig. 8 - The Bethlehem Museum with a stretch of the Roman Aqueduct.

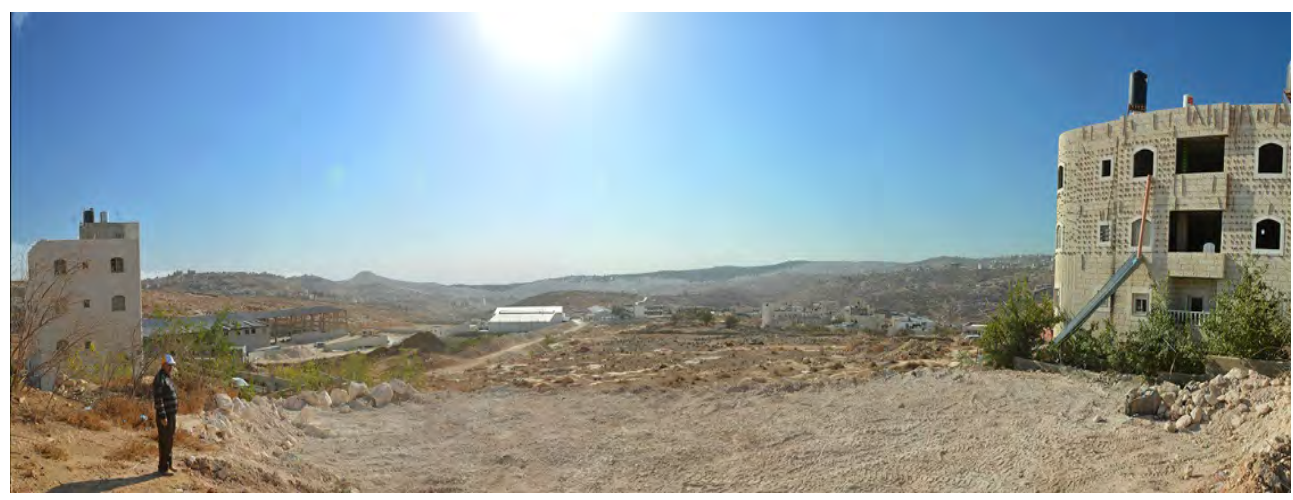

Fig. 9 - Panoramic view of Khalet al-Jam’a necropolis from the upper terrace of Area D. 


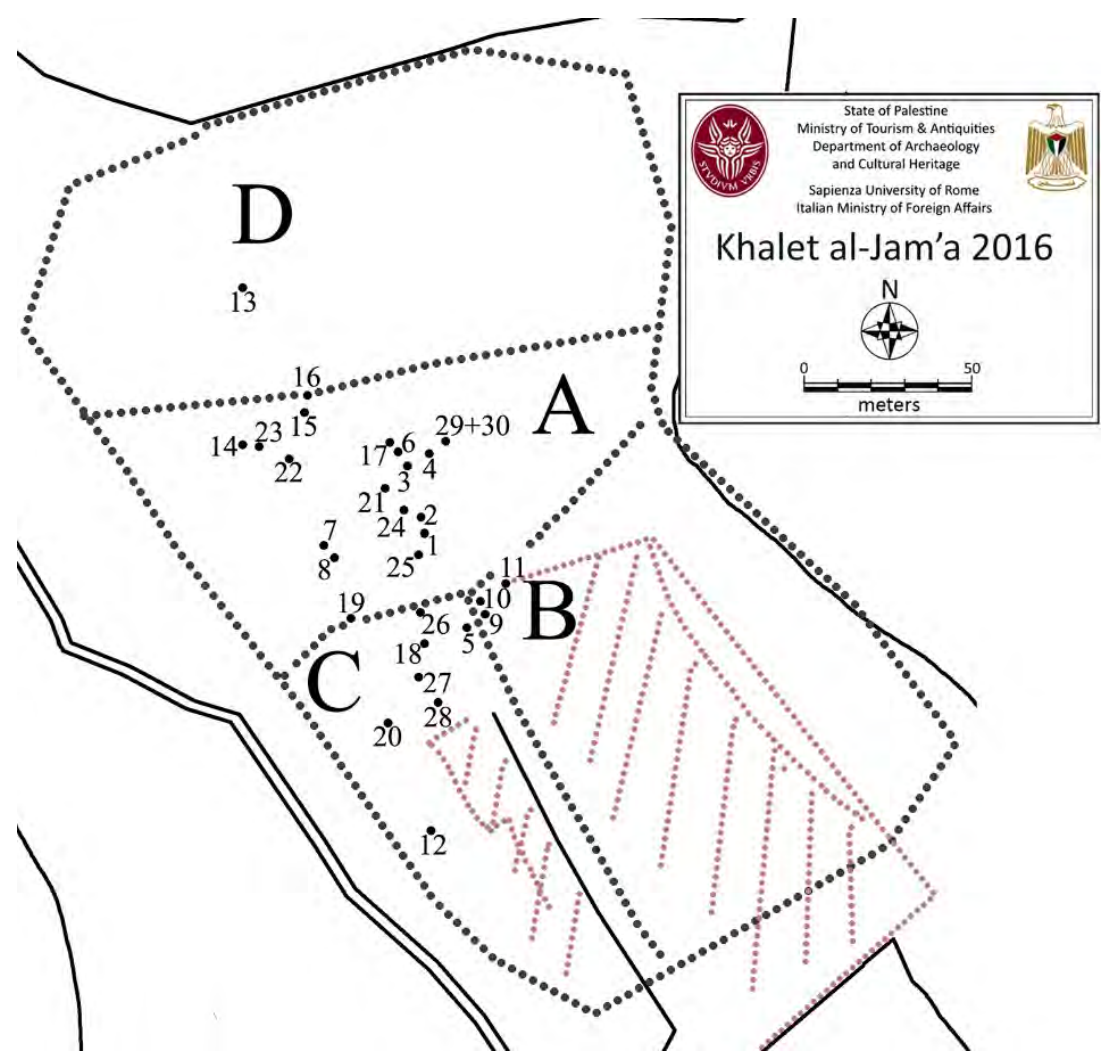

Fig. 10 - Plan of necropolis of Khalet al-Jam’a with areas and tombs.

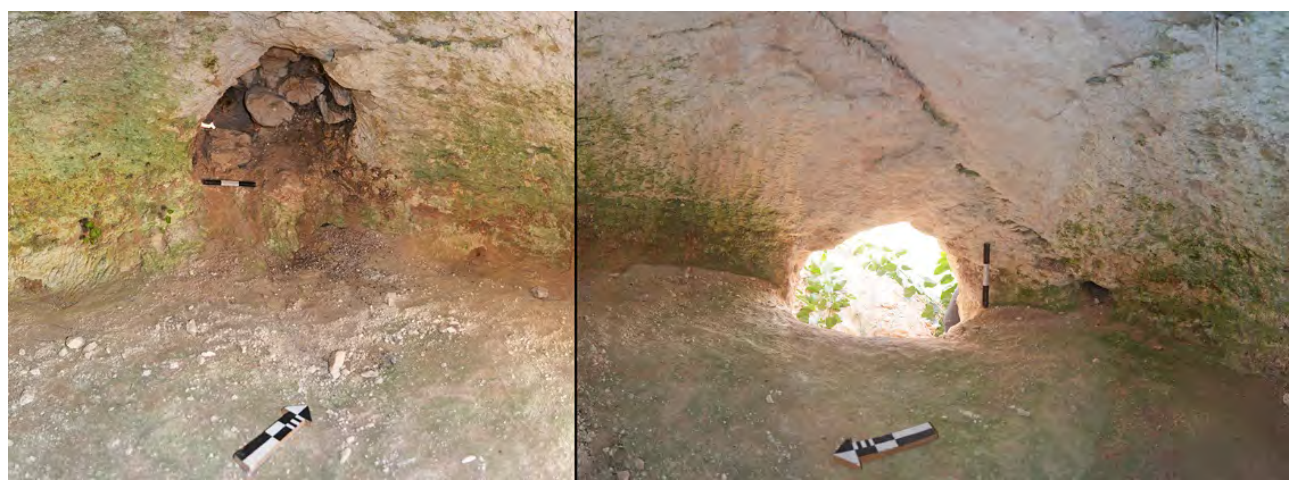

Fig. 11 - Chamber 2 of Tomb A1, the passage communicating with Tomb A2 (left), and the entrance from Chamber 1 (right). 

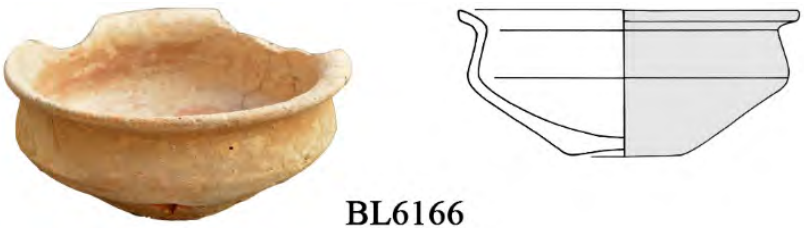

\section{BL6166}
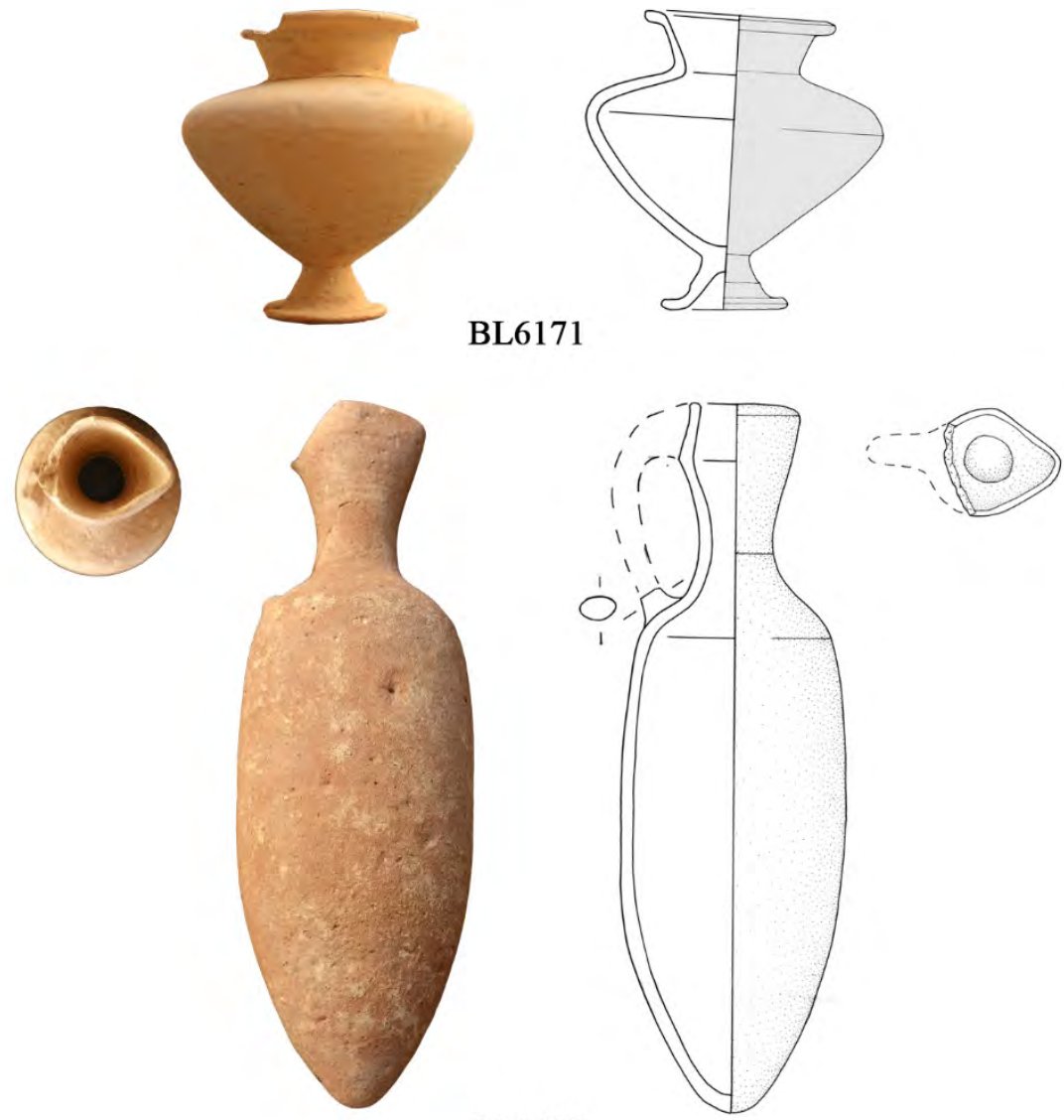

BL6172

Fig. 12 - The 'Gublite' bowl (BL6166) from Chamber 1 of Tomb A1; the White Slip bowl (BL6171) and the dipper juglet (BL6172) from Chamber 3 of Tomb A2 (1:4). 


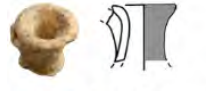

KJ.16.TC5.1/1

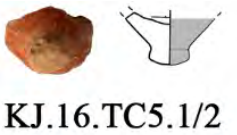

KJ.16.TC5.1/2
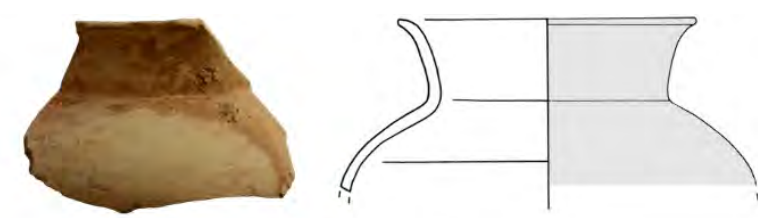

KJ.16.TC5.1/3
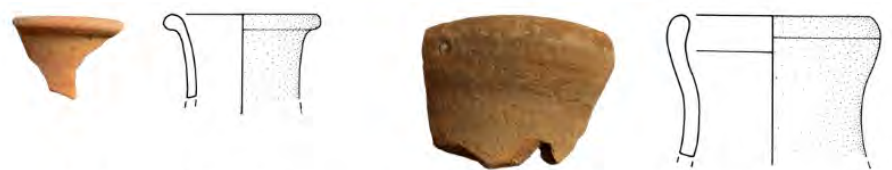

KJ.16.TC5.1/5

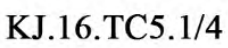

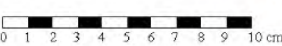

Fig. 13 - Middle Bronze fine ware from Tomb C5 (1:4).
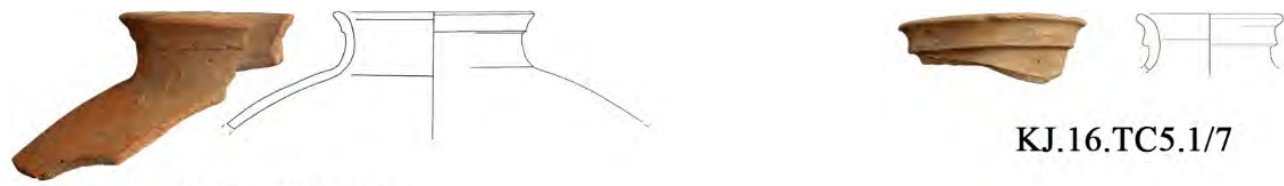

KJ.16.TC5.1/7

KJ.16.TC5.1/6
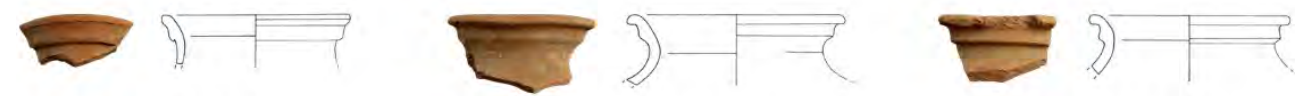

KJ.16.TC5.1/8

KJ.16.TC5.1/9

KJ.16.TC5.1/10

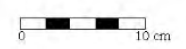

Fig. 14 - Middle Bronze Storage jars from Tomb C5 (1:8).
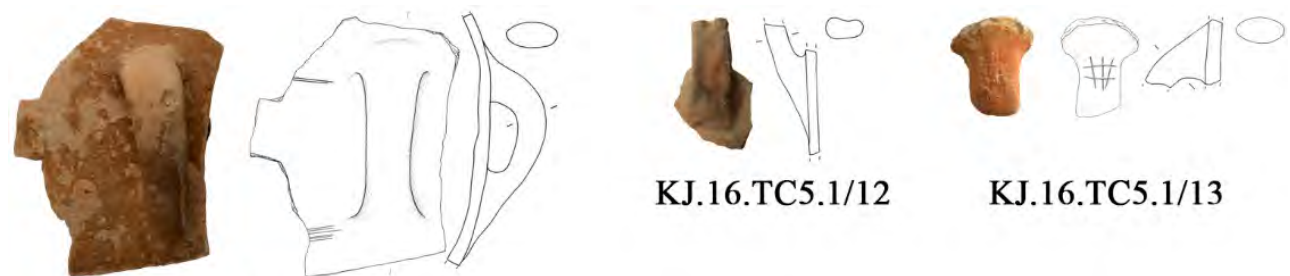

KJ.16.TC5.1/12

KJ.16.TC5.1/13

KJ.16.TC5.1/11
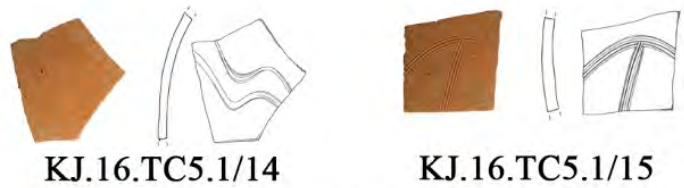

KJ.16.TC5.1/15

Fig. 15 - Middle Bronze Storage ware from Tomb C5 (1:8). 

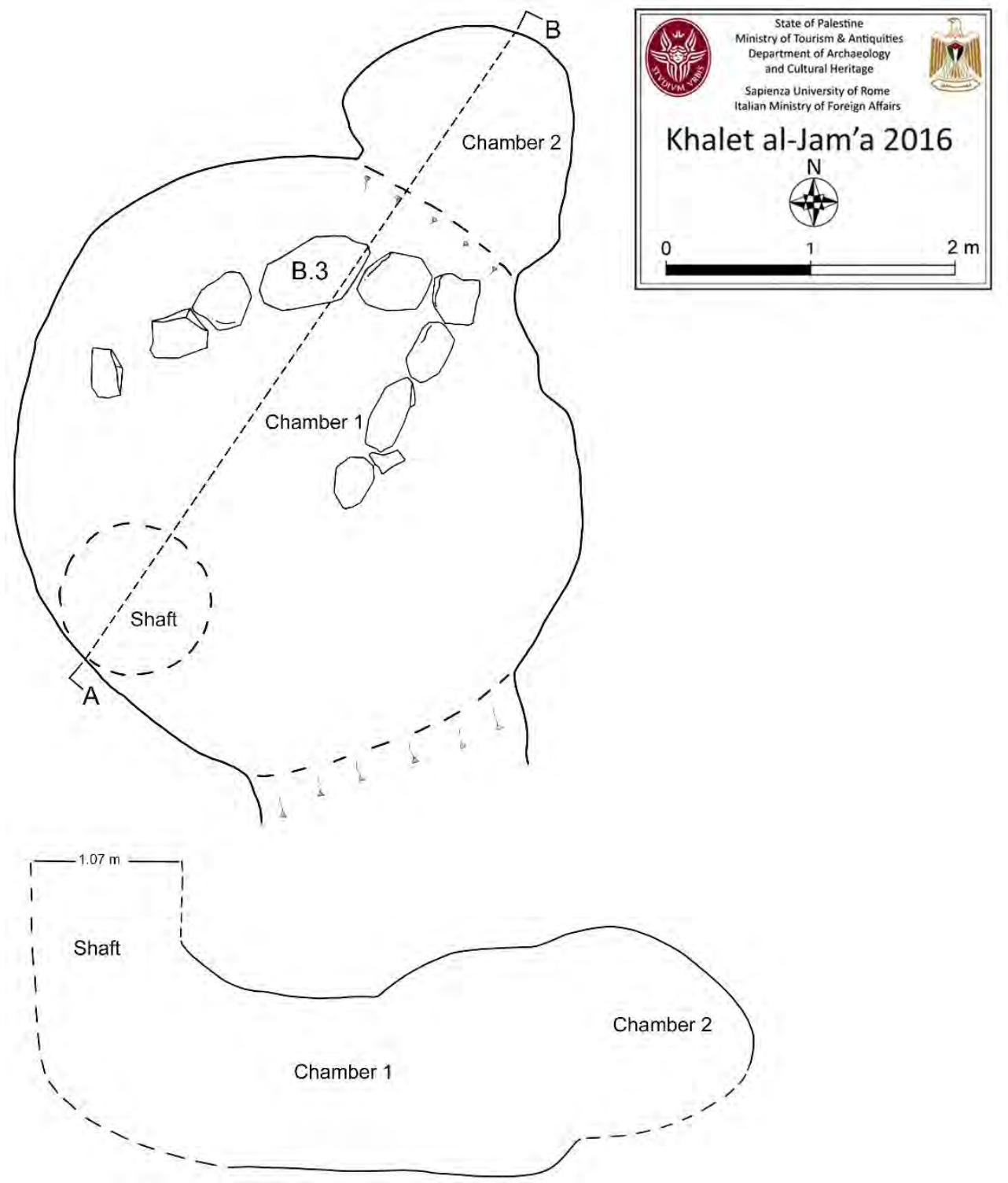

Fig. 16 - Detailed plan of Tomb D13 of Khalet al-Jam'a. 


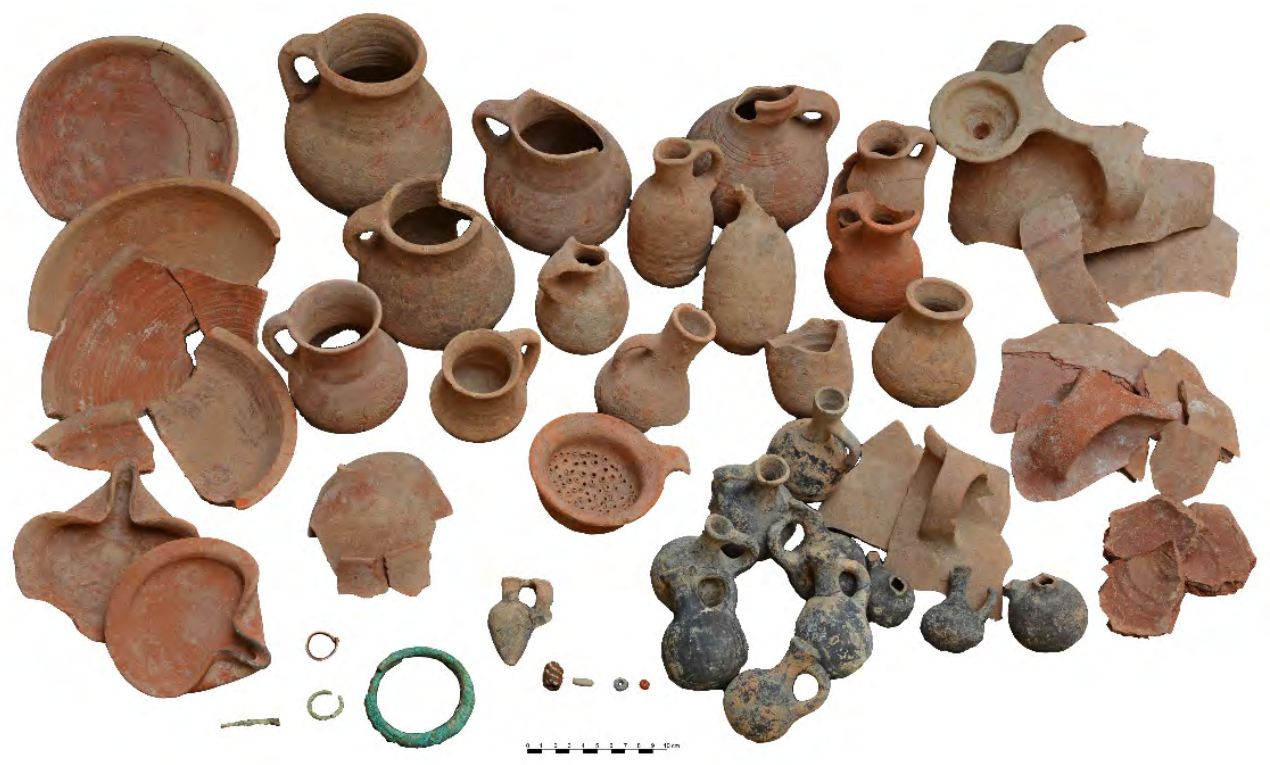

Fig. 17 - Finds from F.1 of Tomb D13 of Khalet al-Jam’a.

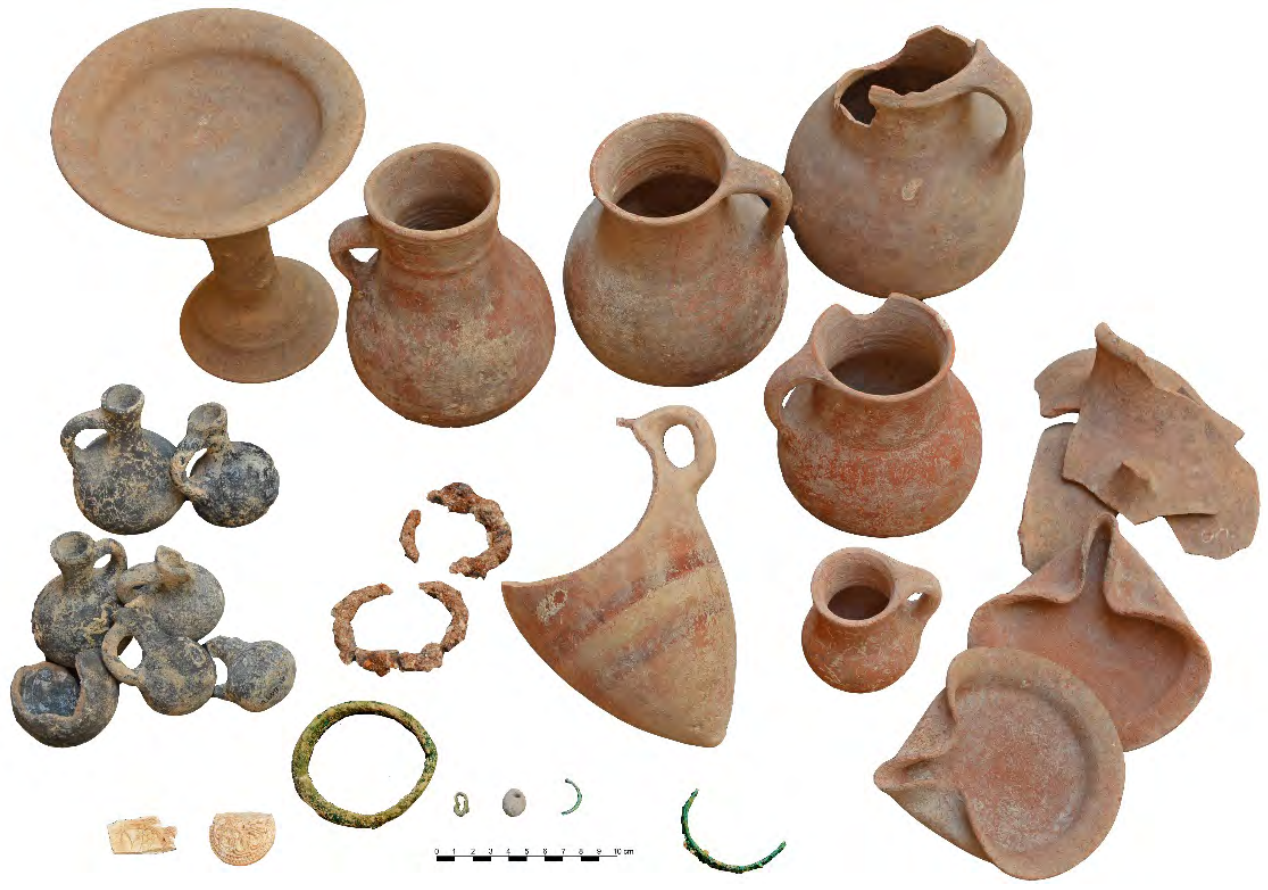

Fig. 18 - Finds from F.2 of Tomb D13 of Khalet al-Jam’a. 
Fig. 19 - Young skull from MB II Tomb B9 of Khalet al-Jam'a (KJ.15.TB9.1.HR.2).

Fig. 20 - Adult male skull from MB II Tomb B10 of Khalet al-Jam'a (KJ.15.TB10.1.HR.1).

Fig. 21 - Young male skull from EB IVB Tomb C12 of Khalet al-Jam'a (KJ.15.TC12.1.HR.1).
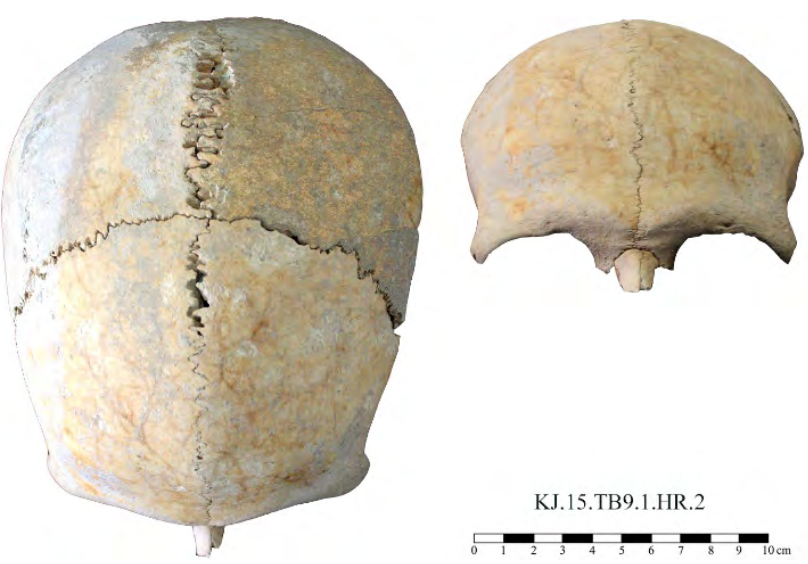

KJ.15.TB9.1.HR.2
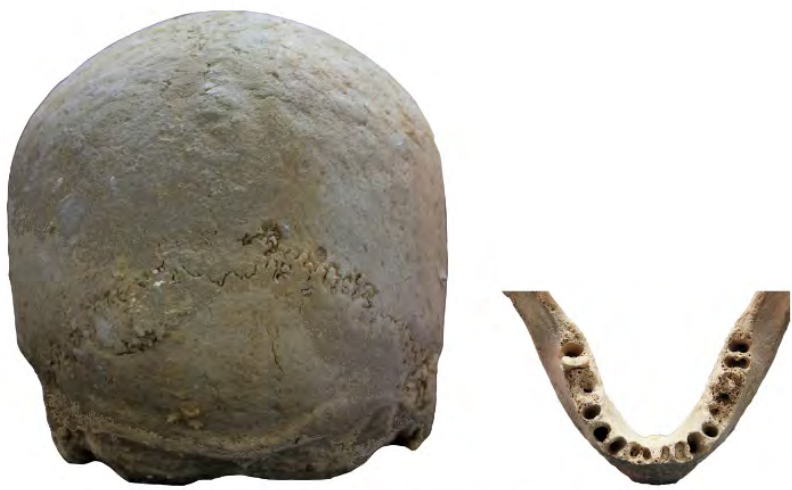

KJ.15.TB10.1.HR.1
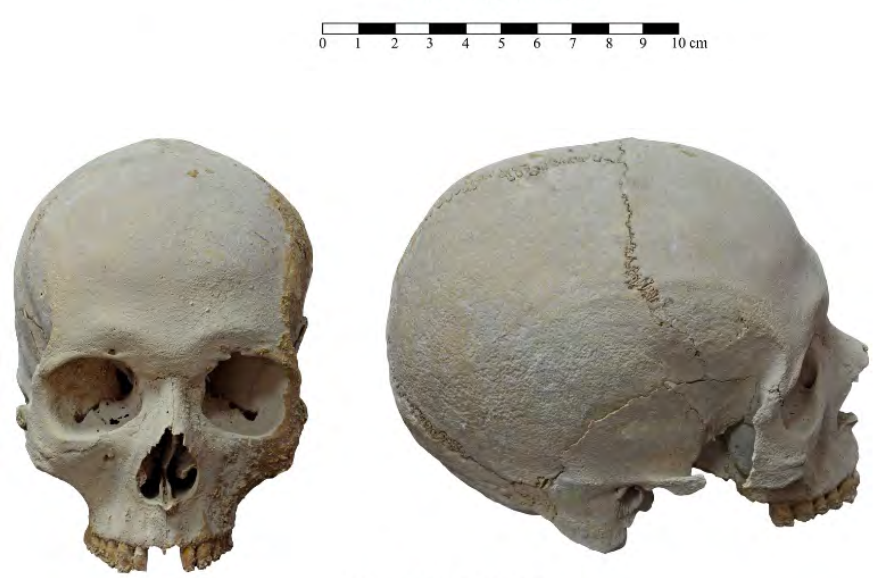

KJ.15.TC12.1.HR.1

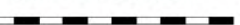




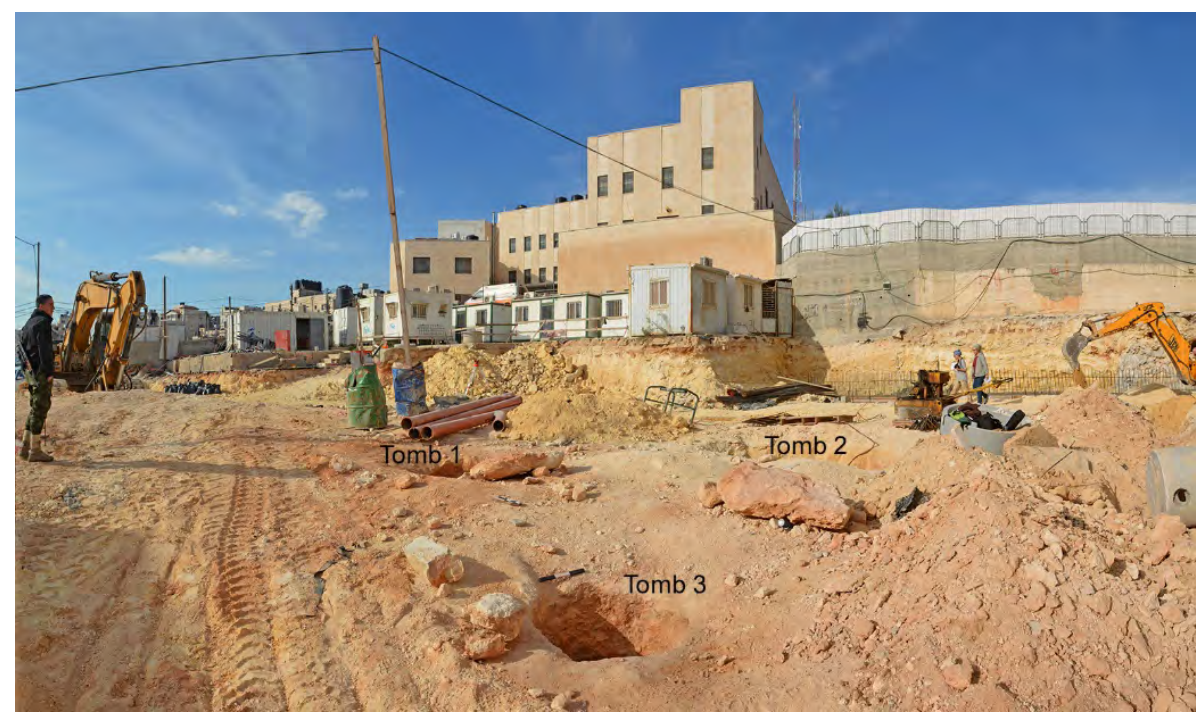

Fig. 22 - The site of Jebel Dhaher during rescue excavations in November 2016, from north-east.

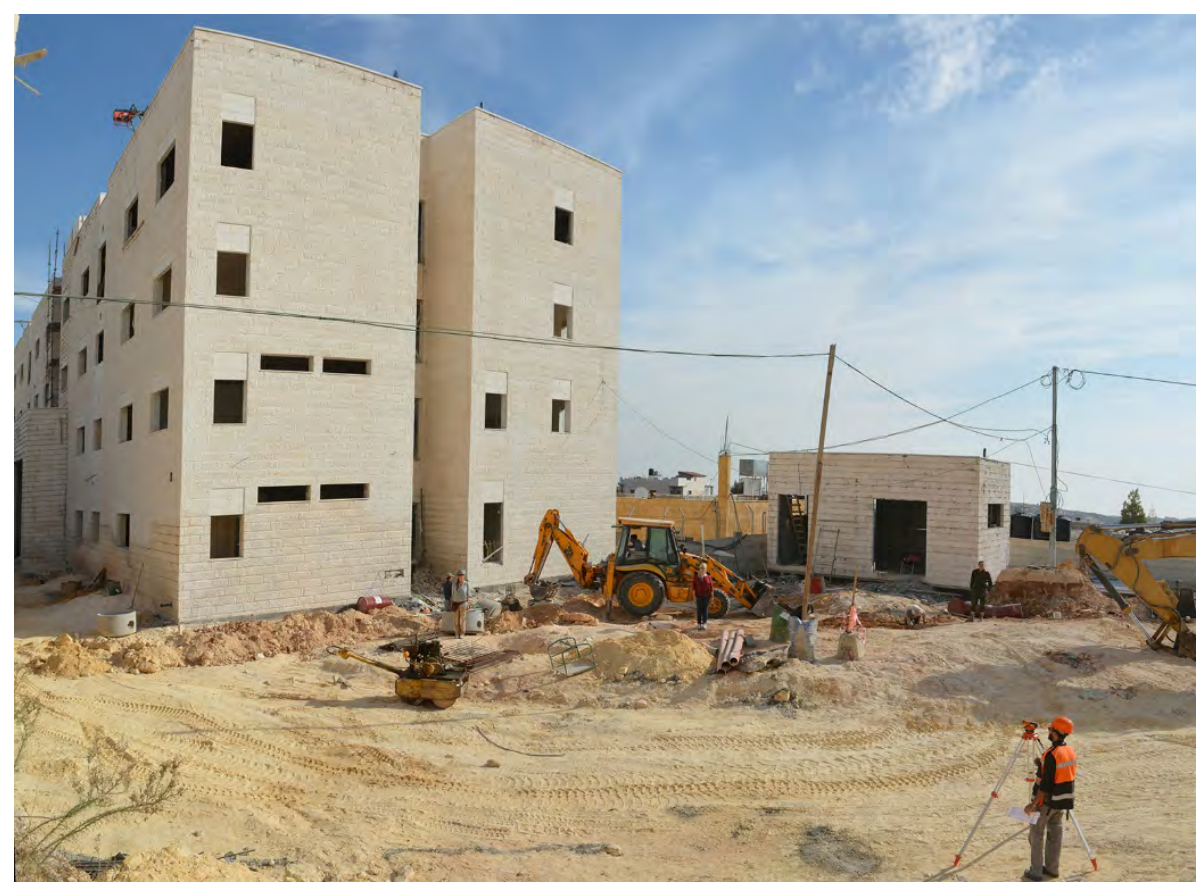

Fig. 23 - The site of Jebel Dhaher during rescue excavations in November 2016, from south-west. 

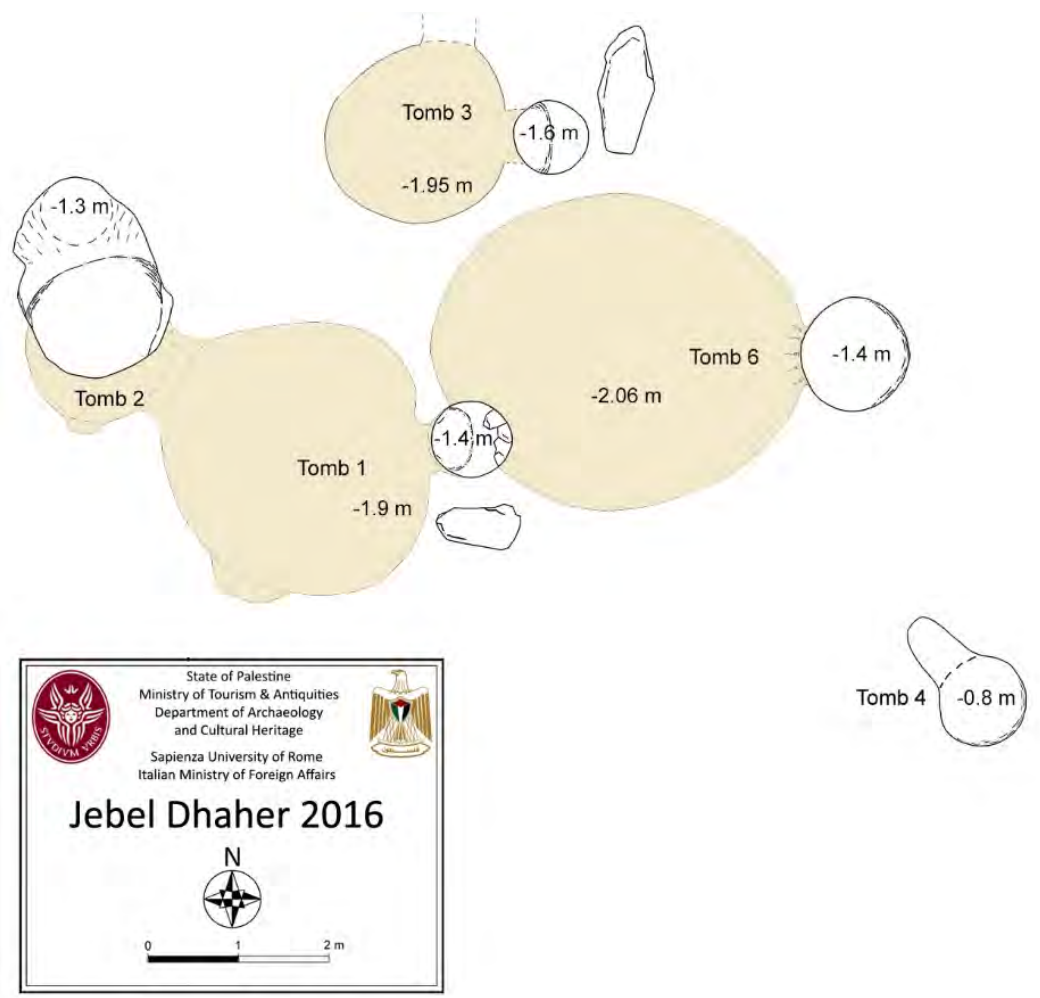

Fig. 24 - Plan of the necropolis of Jebel Dhaher with tombs discovered in Autumn 2016.

Fig. 25 - Tomb A of Jebel Dhaher before its concealing under the concrete wall.

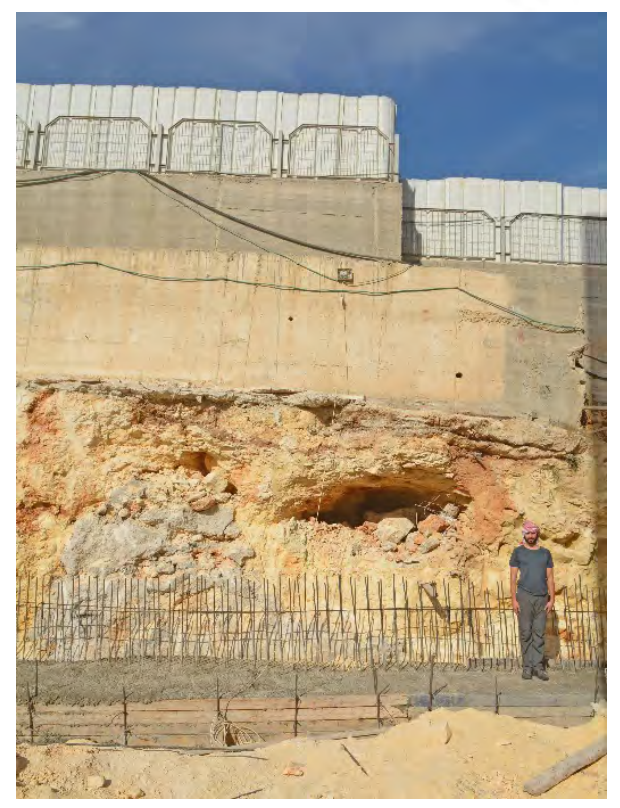




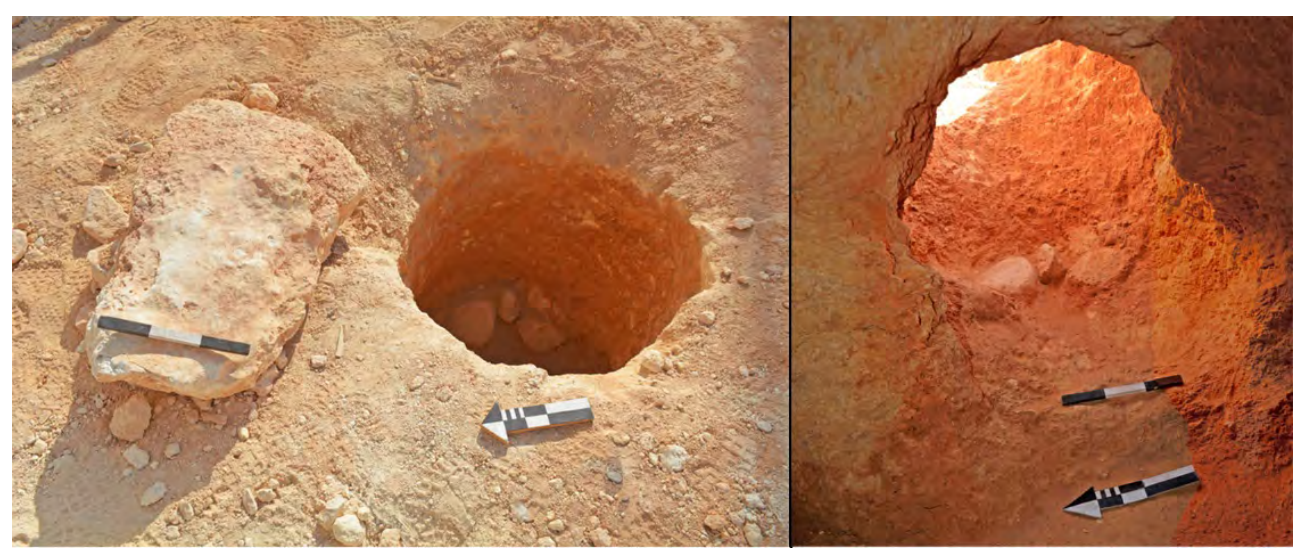

Fig. 26 - Shaft and closing stone (left), and shaft from the inside (right) of Tomb 1 of Jebel Dhaher.

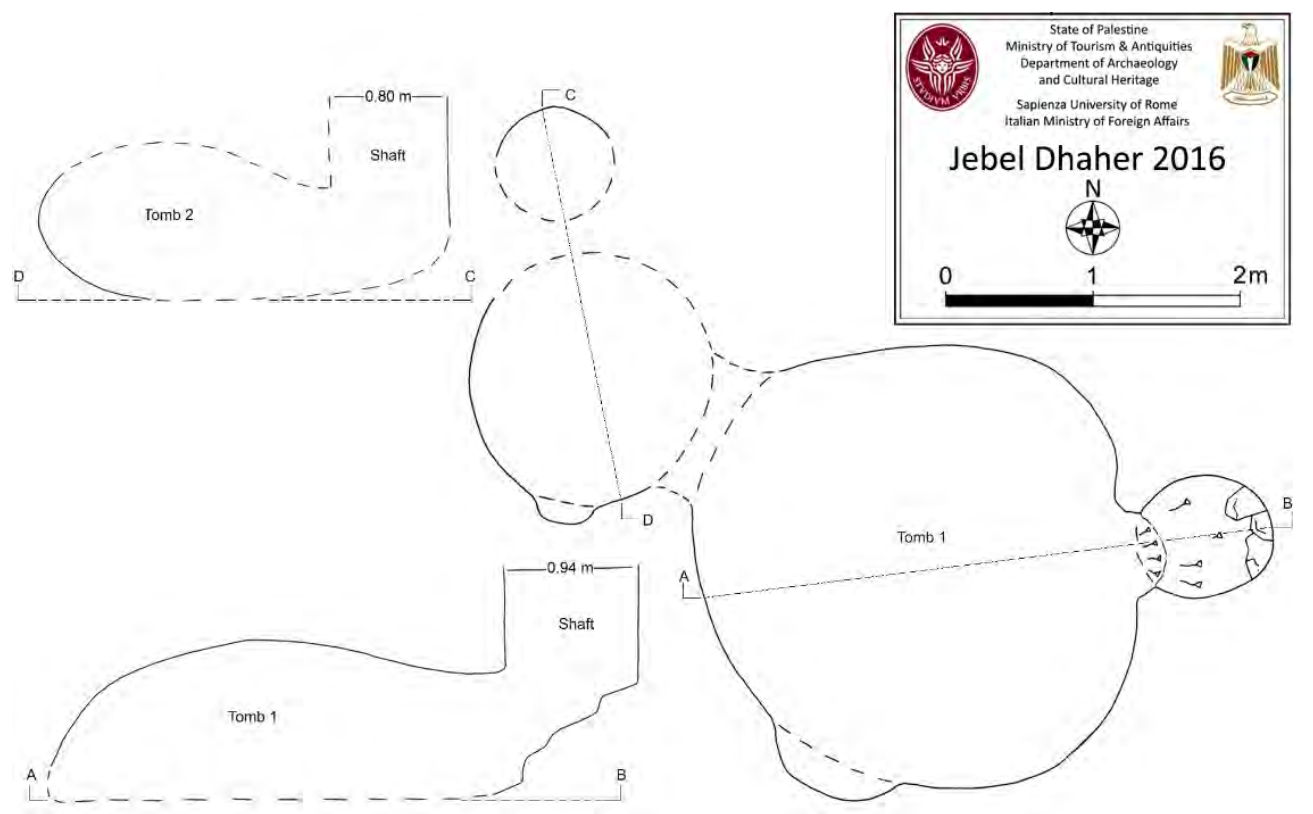

Fig. 27 - Plan of Tombs 1 and 2 of Jebel Dhaher. 

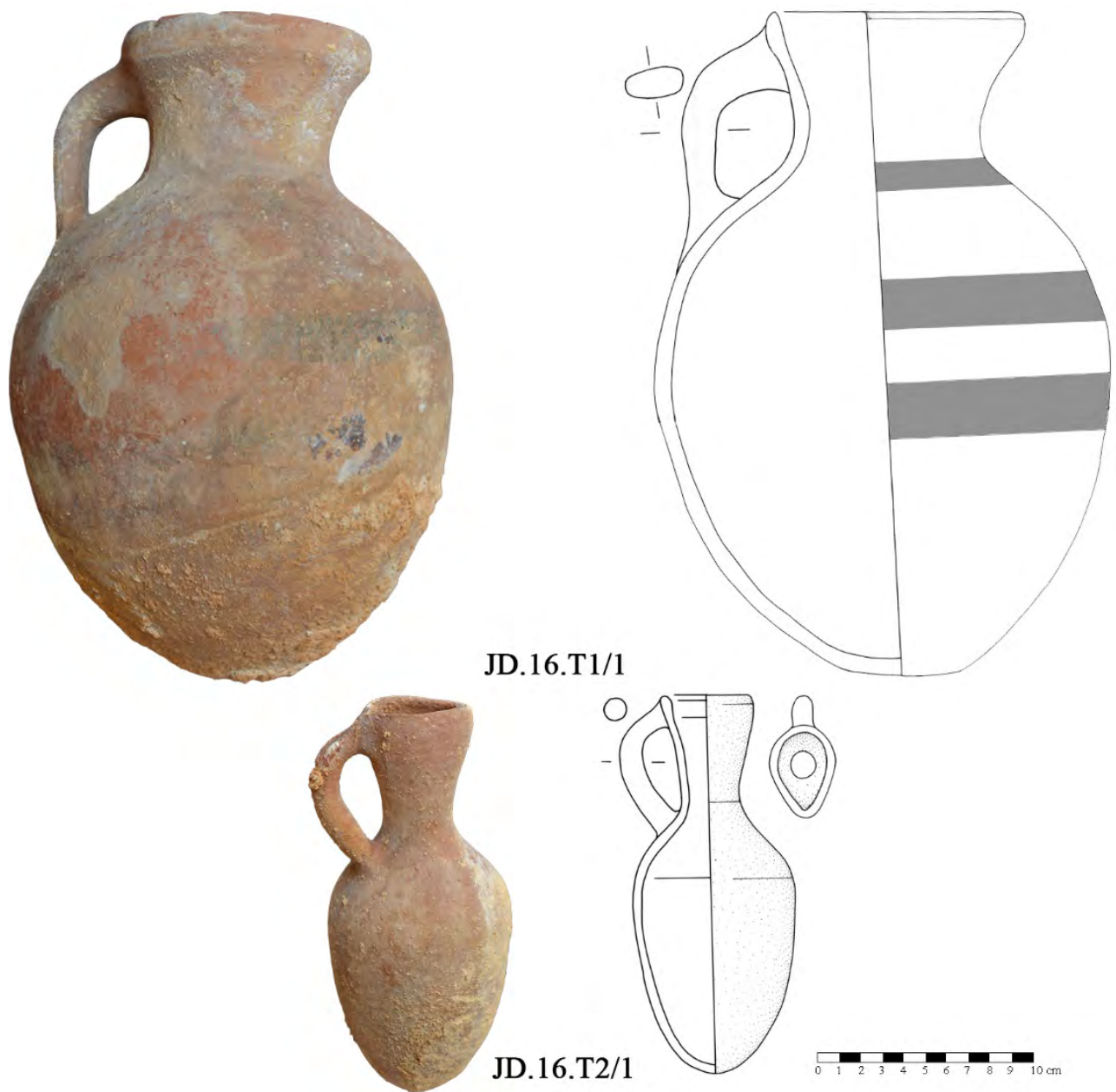

Fig. 28 - Middle Bronze pottery from Tomb 1 (JD.16.T1/1) and Tomb 2 (JD.16.T2/1) of Jebel Dhaher (1:4).

Fig. 29 - Tomb 2 of Jebel Dhaher, from north.

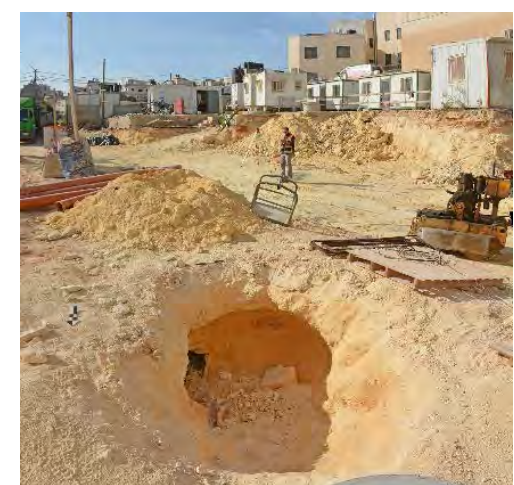



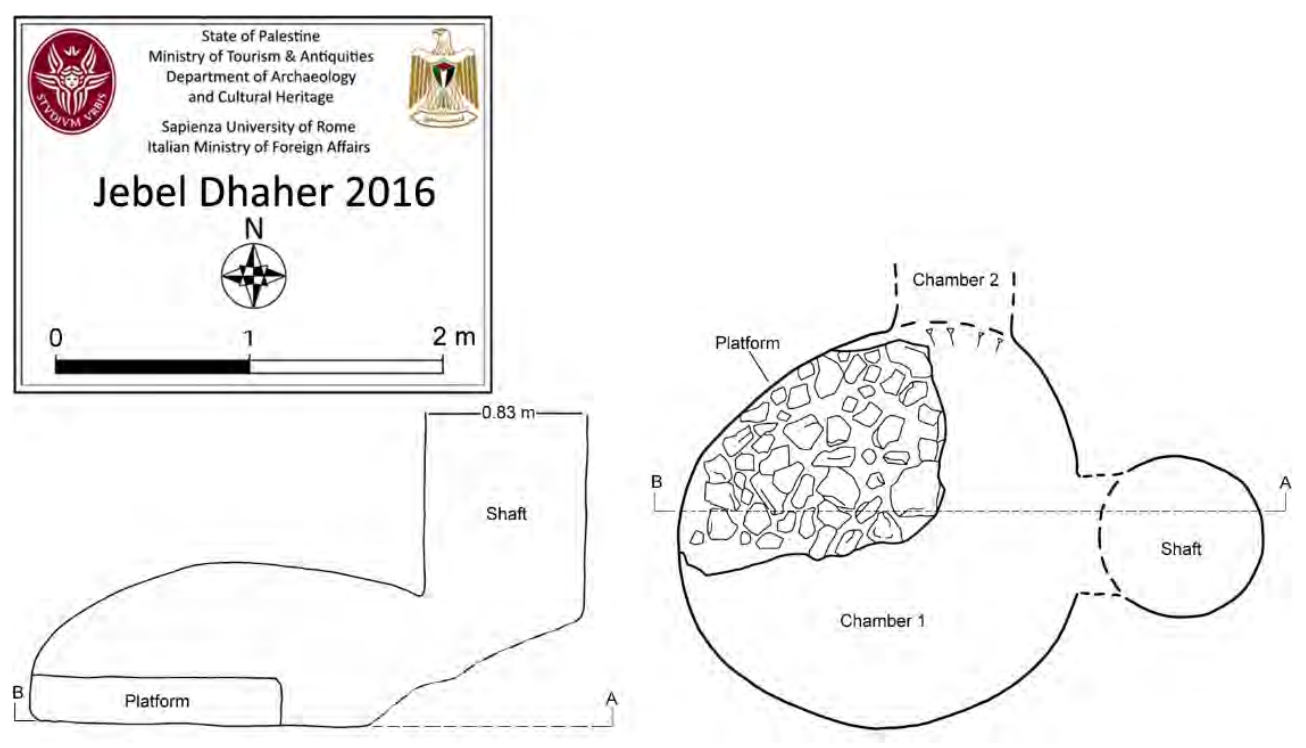

Fig. 30 - Plan of Tomb 3 of Jebel Dhaher.

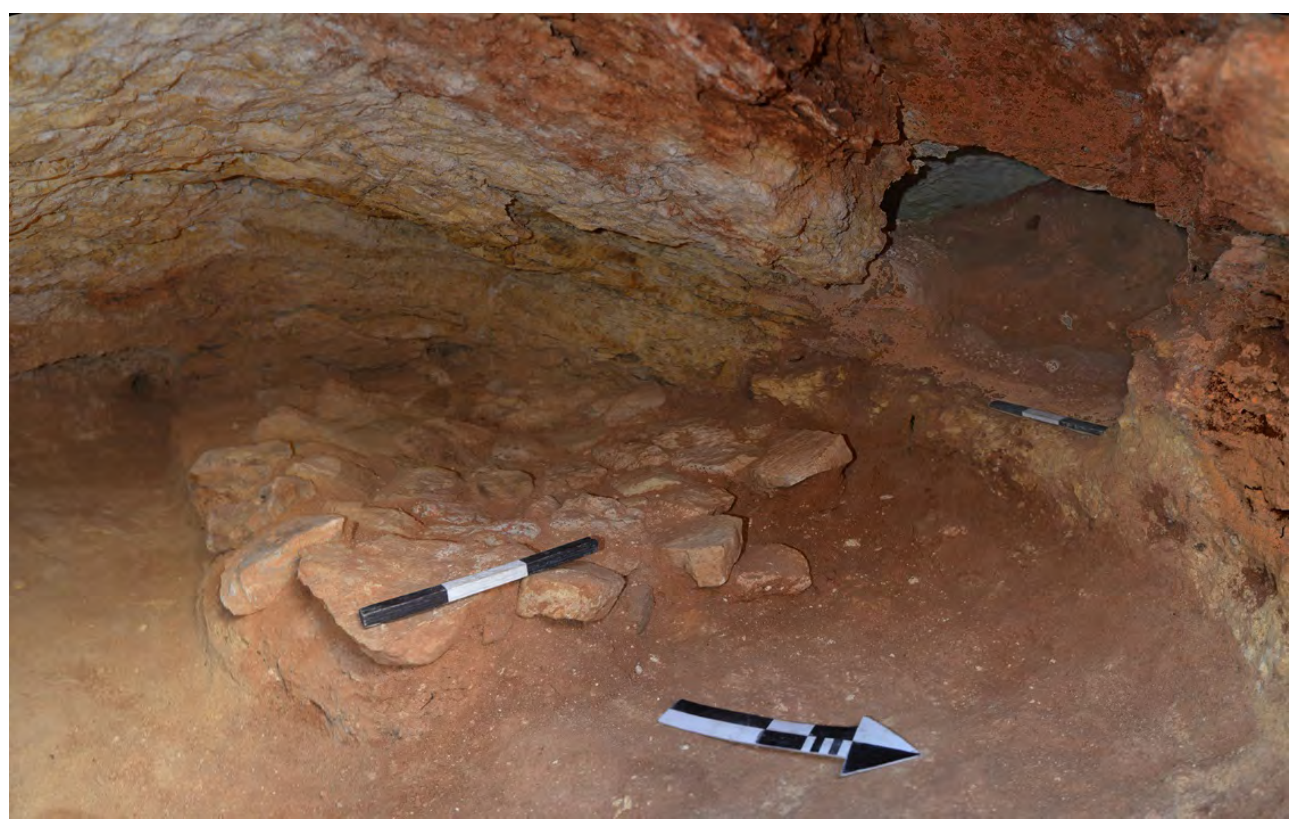

Fig. 31 - The stone platform B.3 in Chamber 1 and the passage to Chamber of Tomb 3 of Jebel Dhaher. 

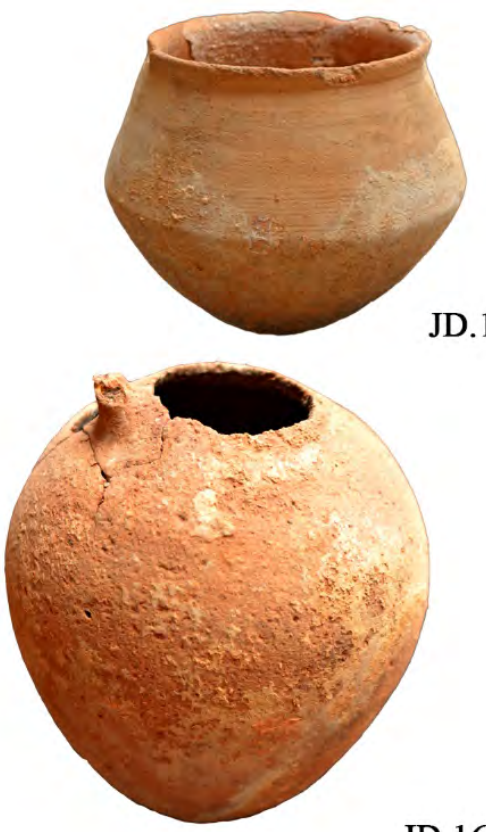

JD.16.T3.3/1

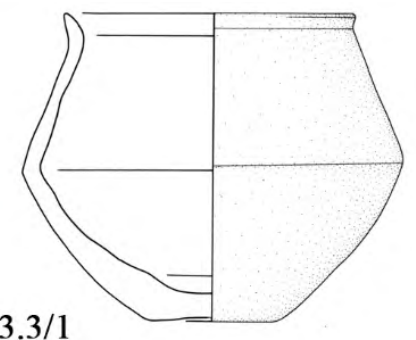

JD.16.T3.3/2

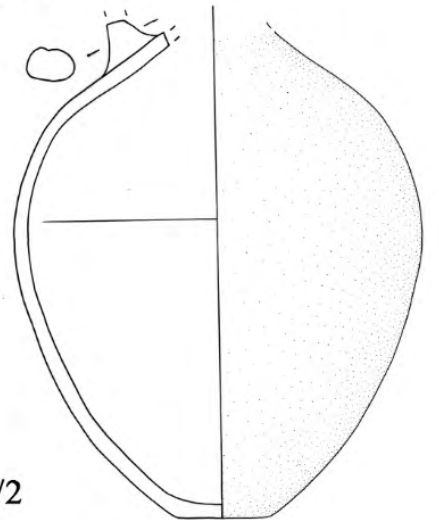

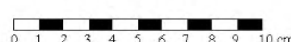

Fig. 32 - Middle Bronze pottery equipment of Tomb 3 of Jebel Dhaher (1:4).

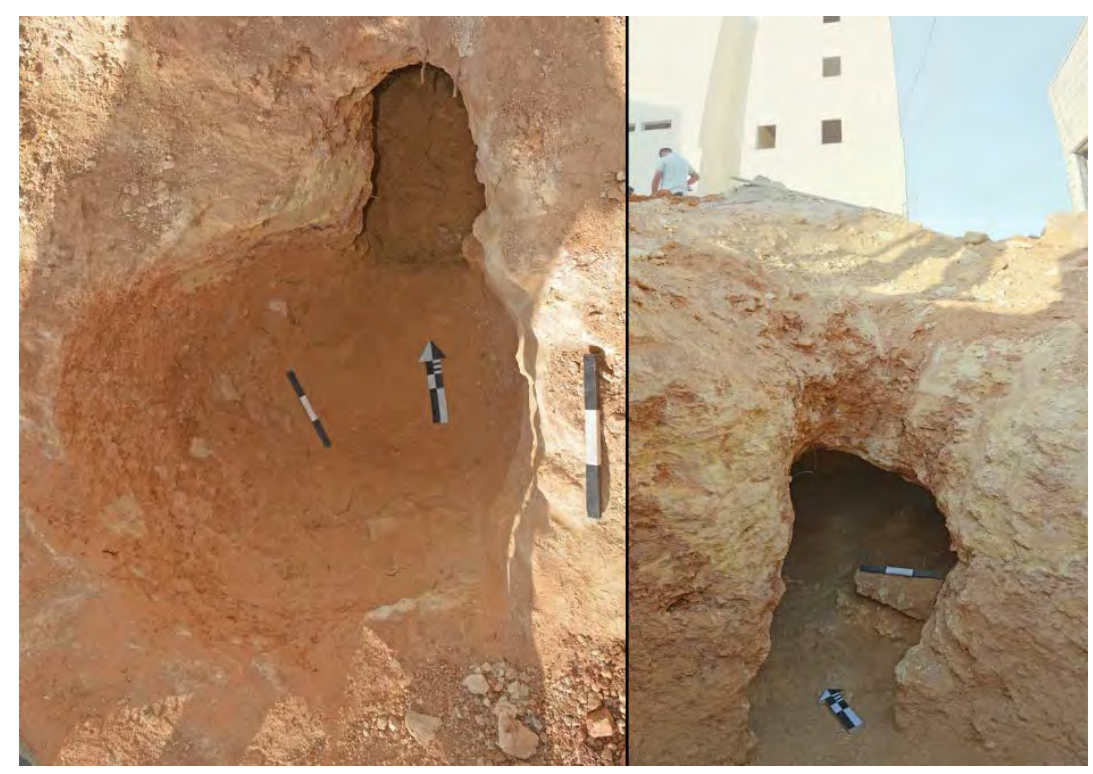

Fig. 33 - Shaft and entrance of Tomb 5 of Jebel Dhaher. 

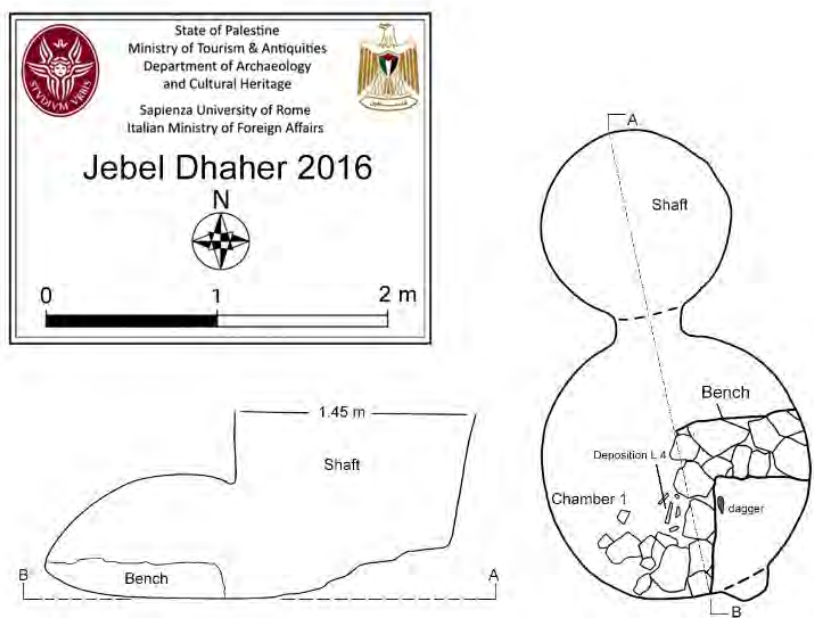

Fig. 34 - Plan of Tomb 5 of Jebel Dhaher.

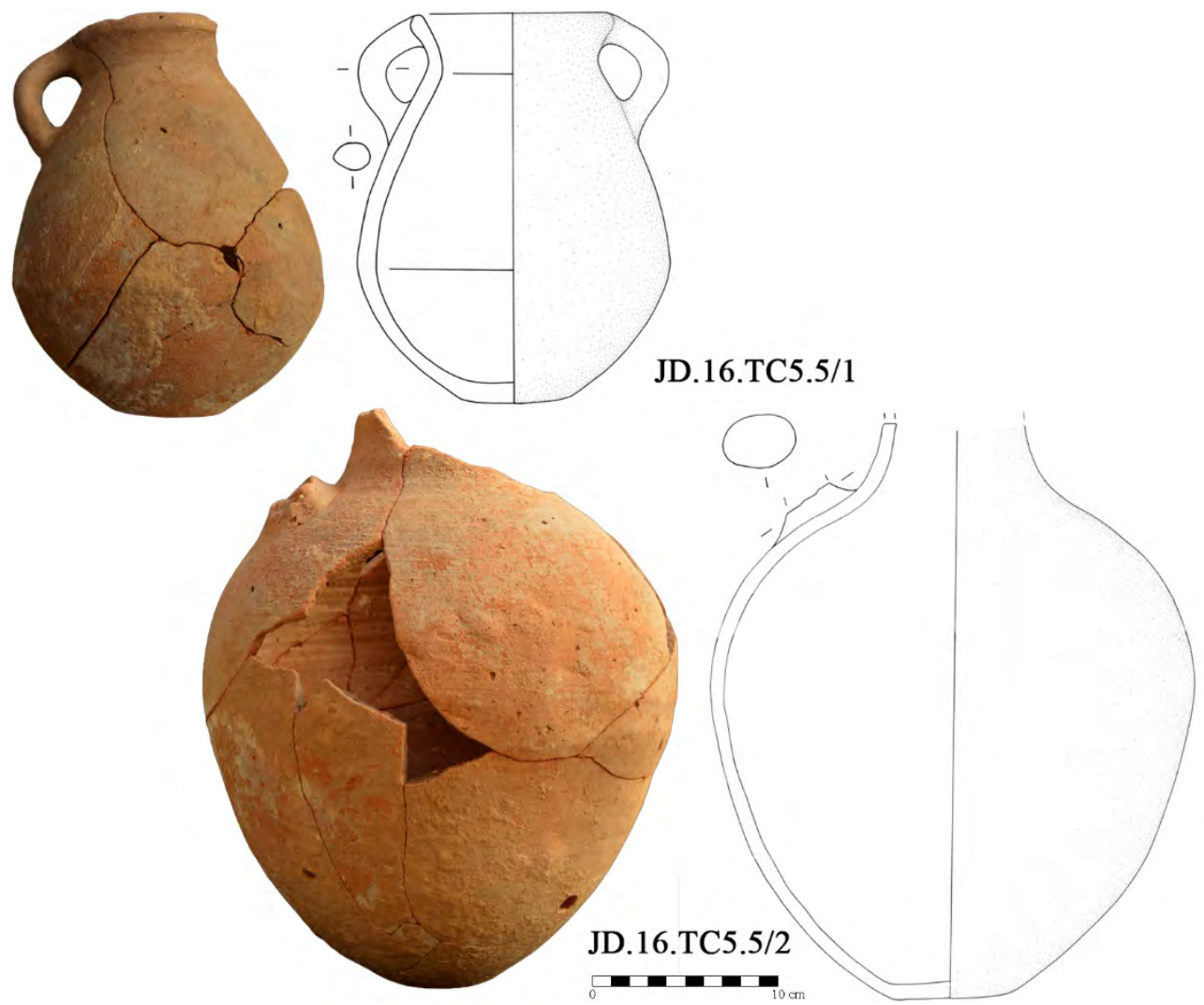

Fig. 35 - Iron Age pottery equipment of Tomb 5, from JD.T5.F.5 (1:4). 


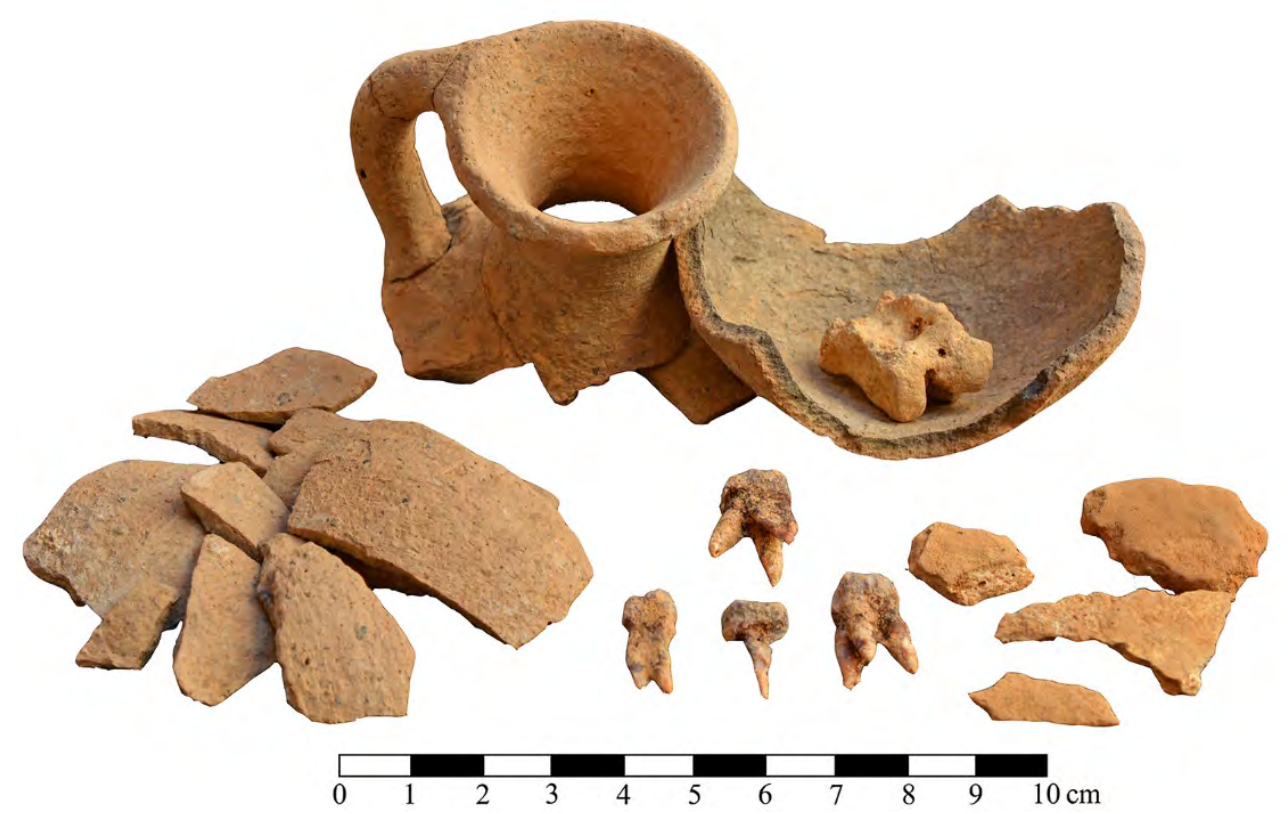

Fig. 36 - The Iron Age Burial B5.1 from Tomb 5 of Jebel Dhaher.
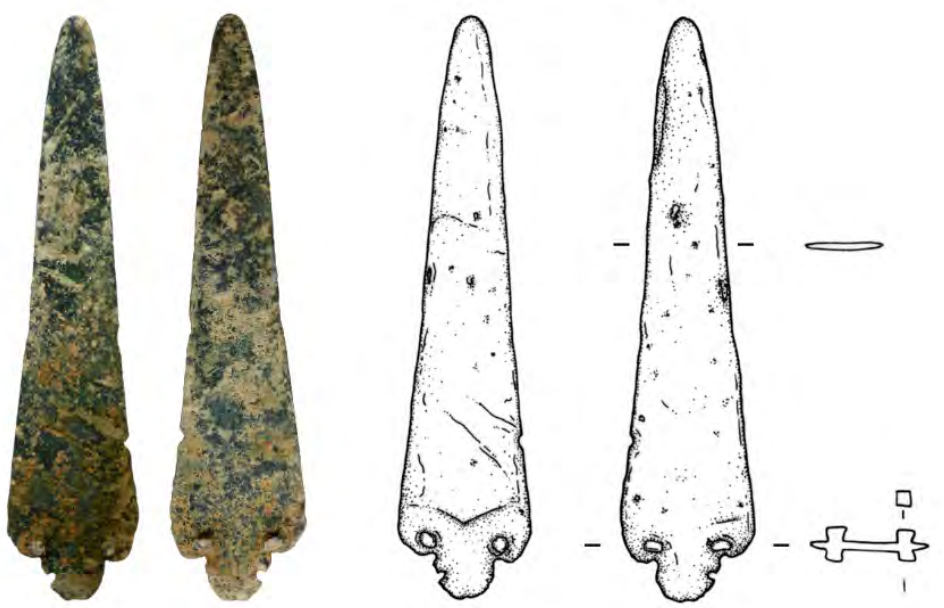

JD.16.T5.1

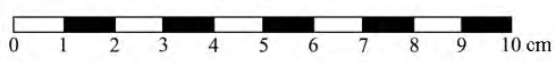

Fig. 37 - Intermediate Bronze Age copper dagger from Tomb 5 of Jebel Dhaher. 


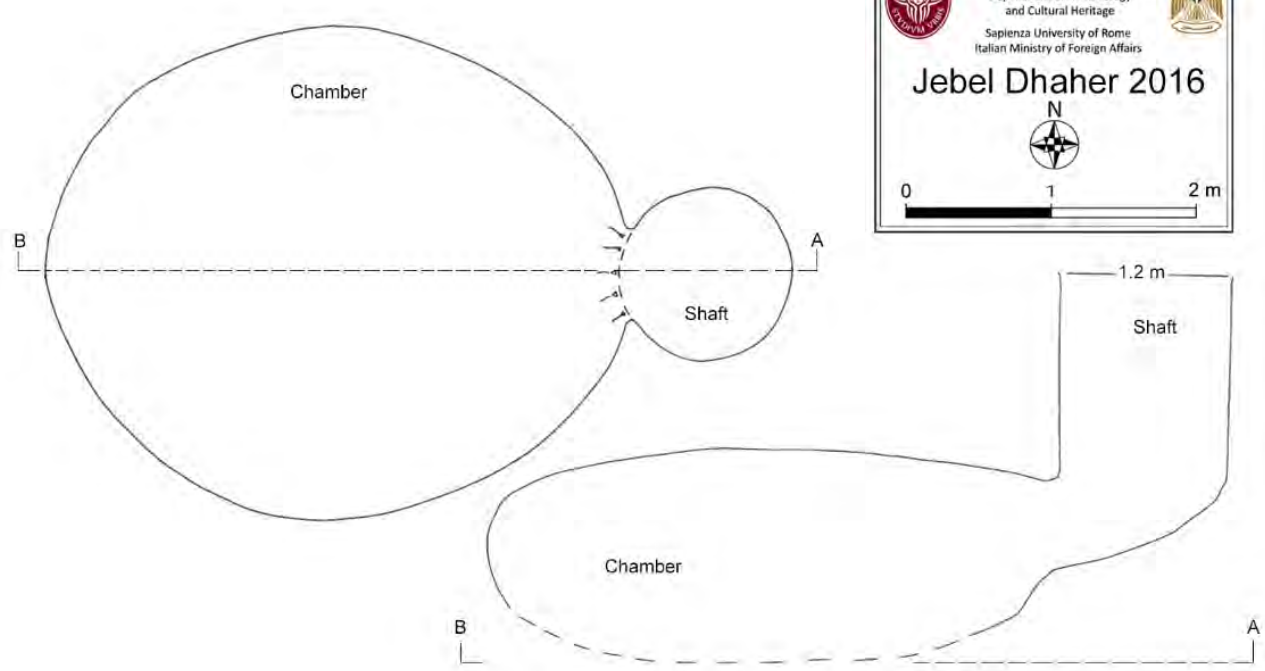

Fig. 38 - Plan of Tomb 6 of Jebel Dhaher.

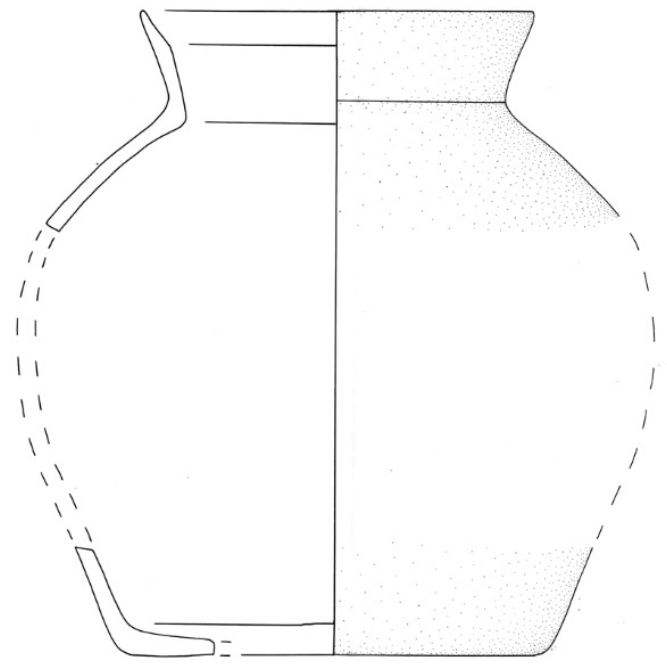

JD.16.T6.1/1

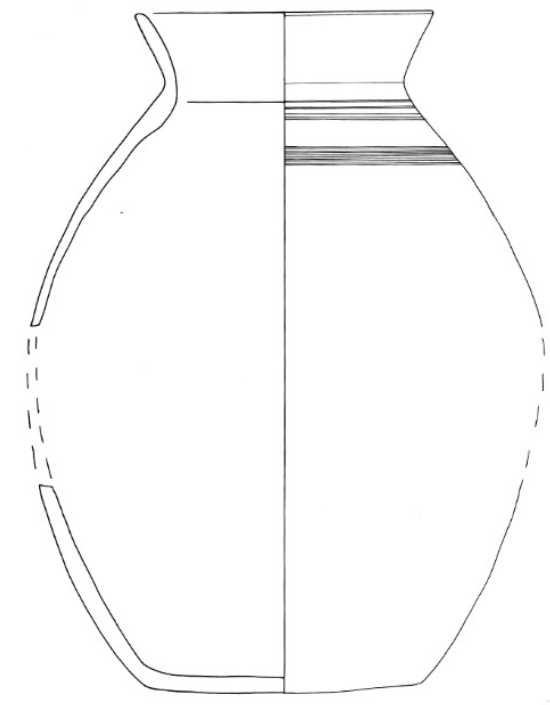

JD.16.T6.3/1

Fig. 39 - Early Bronze IVB pottery equipment of Tomb 6 of Jebel Dhaher (1:4). 


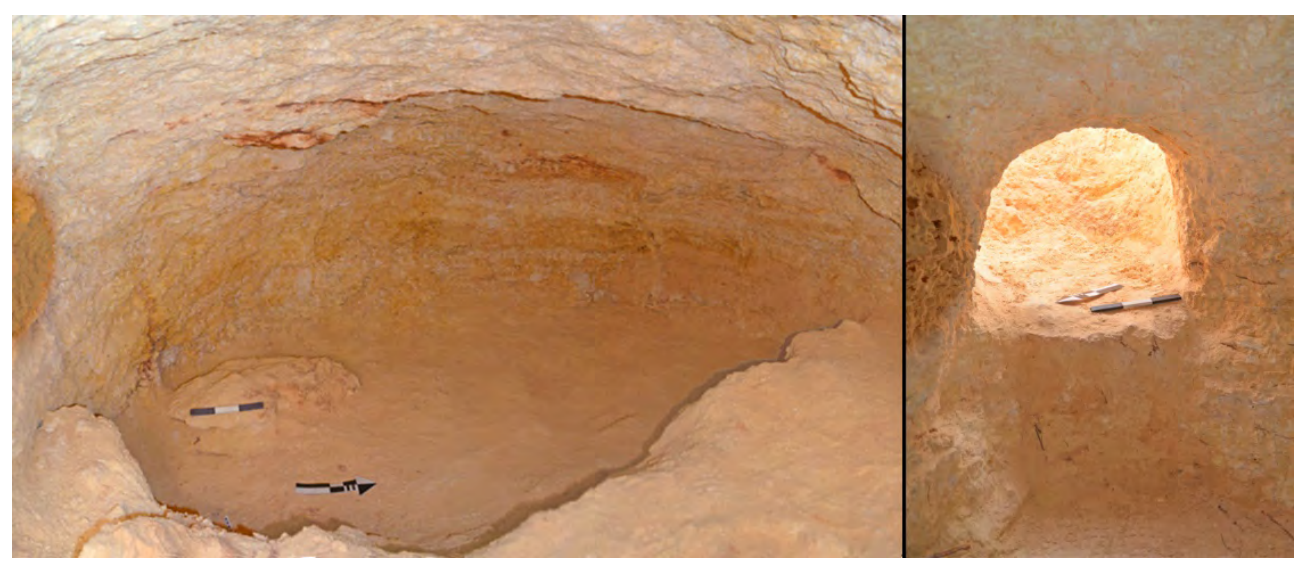

Fig. 40 - Chamber (left) and entrance (right) of Tomb 6 of Jebel Dhaher.

Fig. 41 - Multiple burials (JD.16.T1.3.HR.1) on stone platform B.3 of Tomb 1 of Jebel Dhaher.
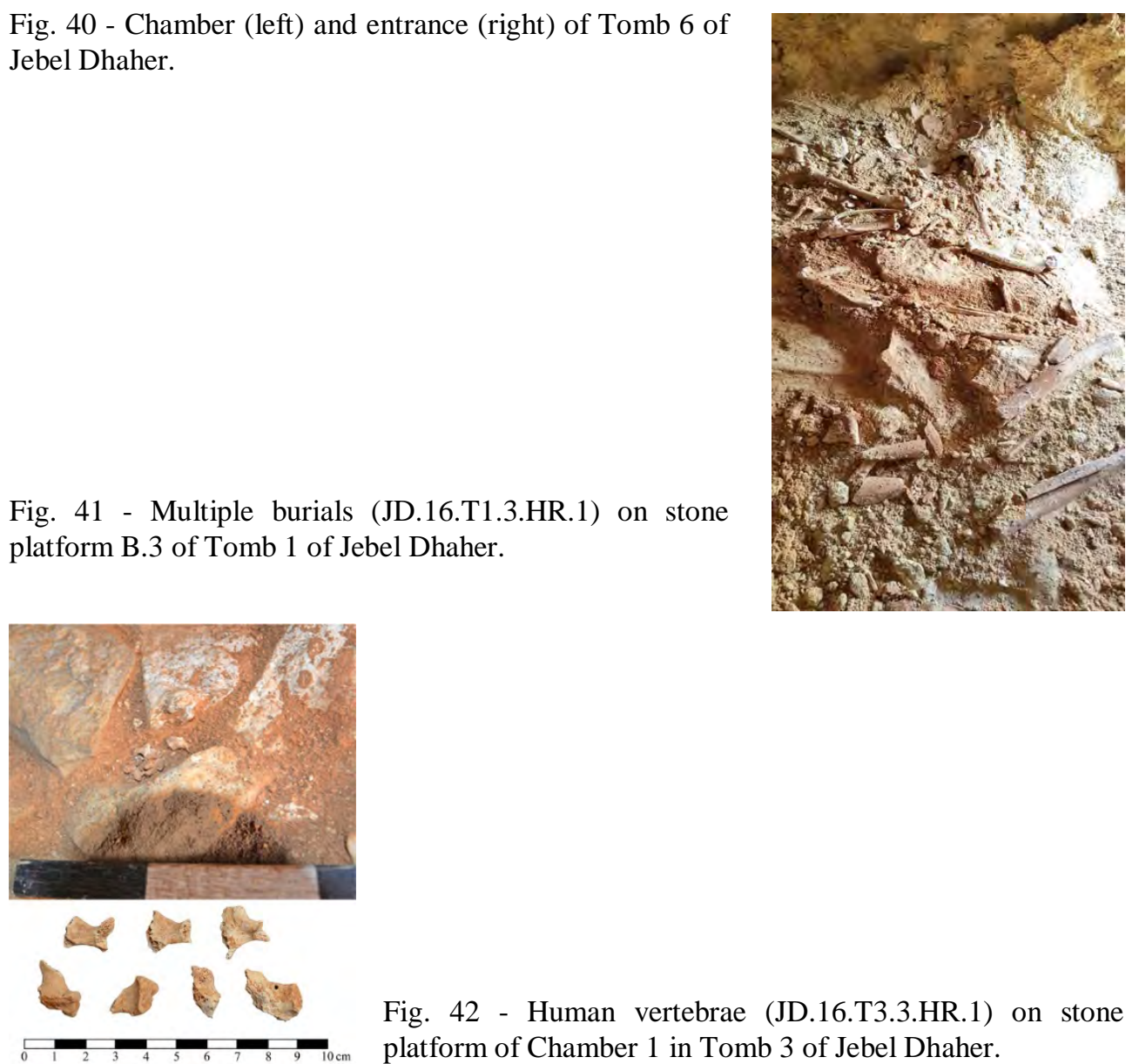

Fig. 42 - Human vertebrae (JD.16.T3.3.HR.1) on stone platform of Chamber 1 in Tomb 3 of Jebel Dhaher. 


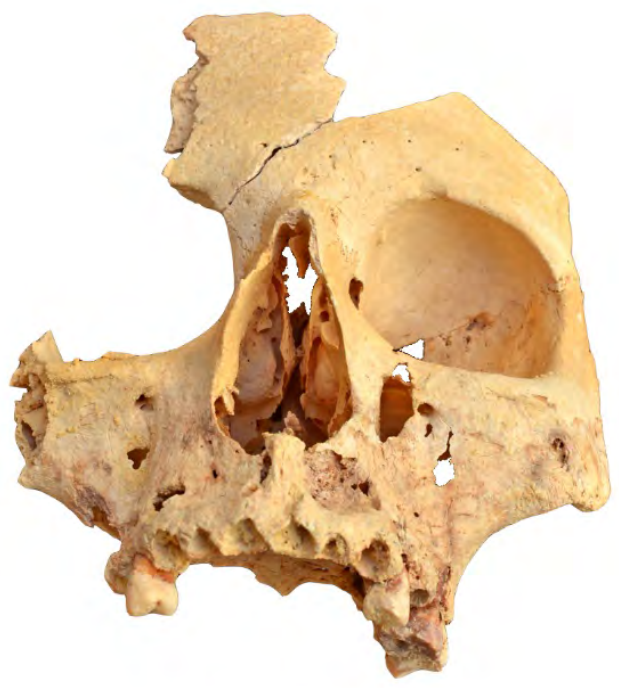

JD.16.T6.2.HR.2

Fig. 43 - Young female skull (JD.16.T6.2.HR.2) from Tomb 6 of Jebel Dhaher.

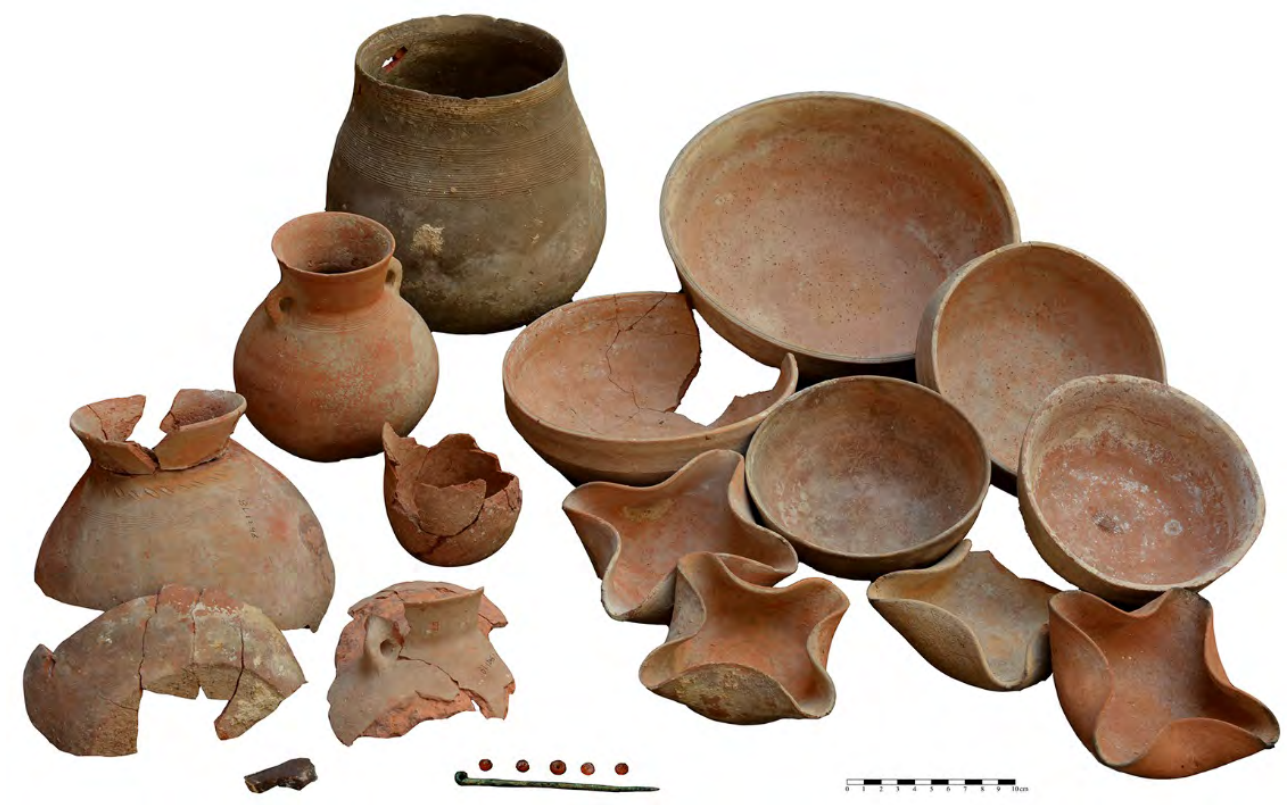

Fig. 44 - Early Bronze IVB funerary equipment of el-Atan Tomb. 


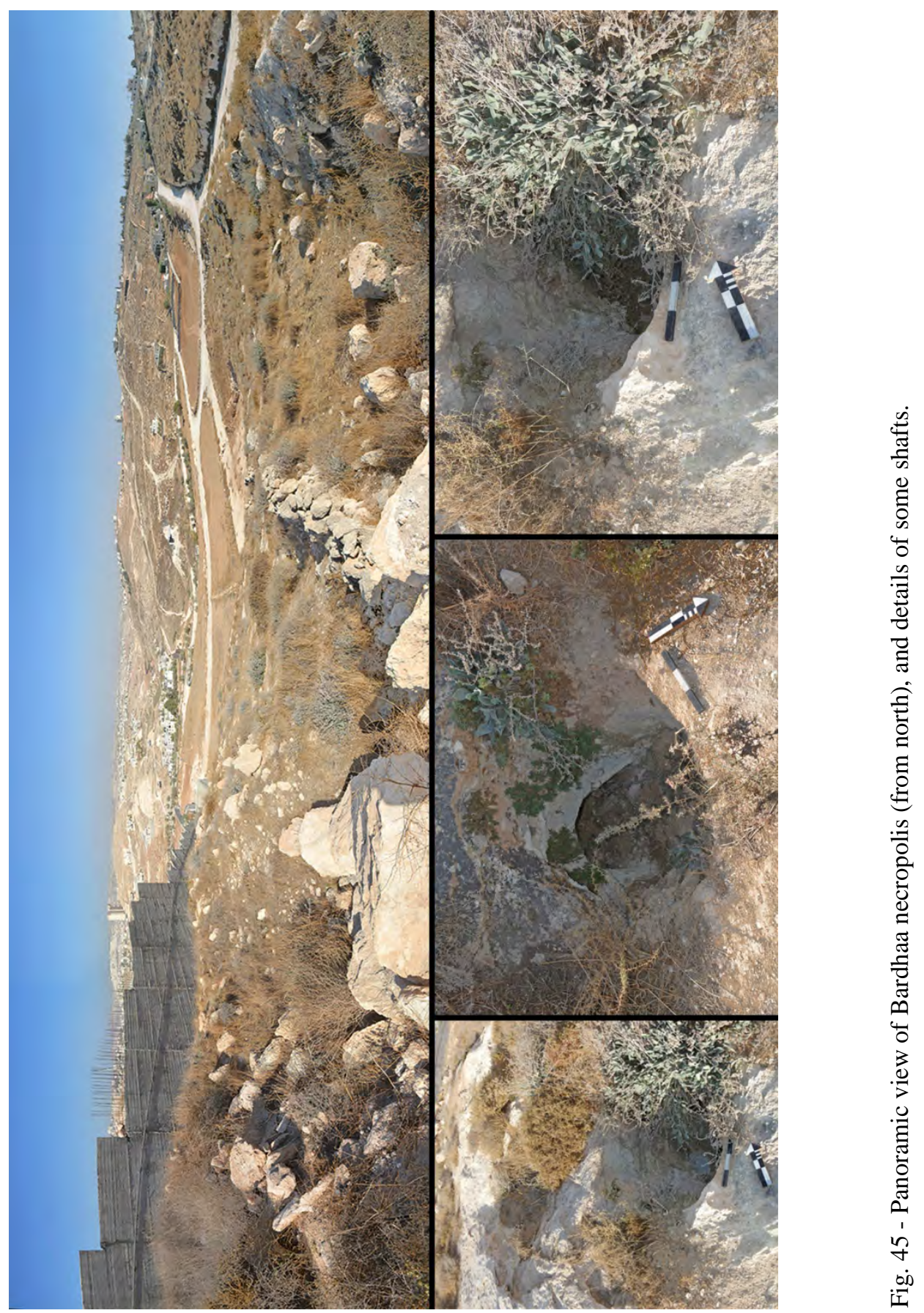




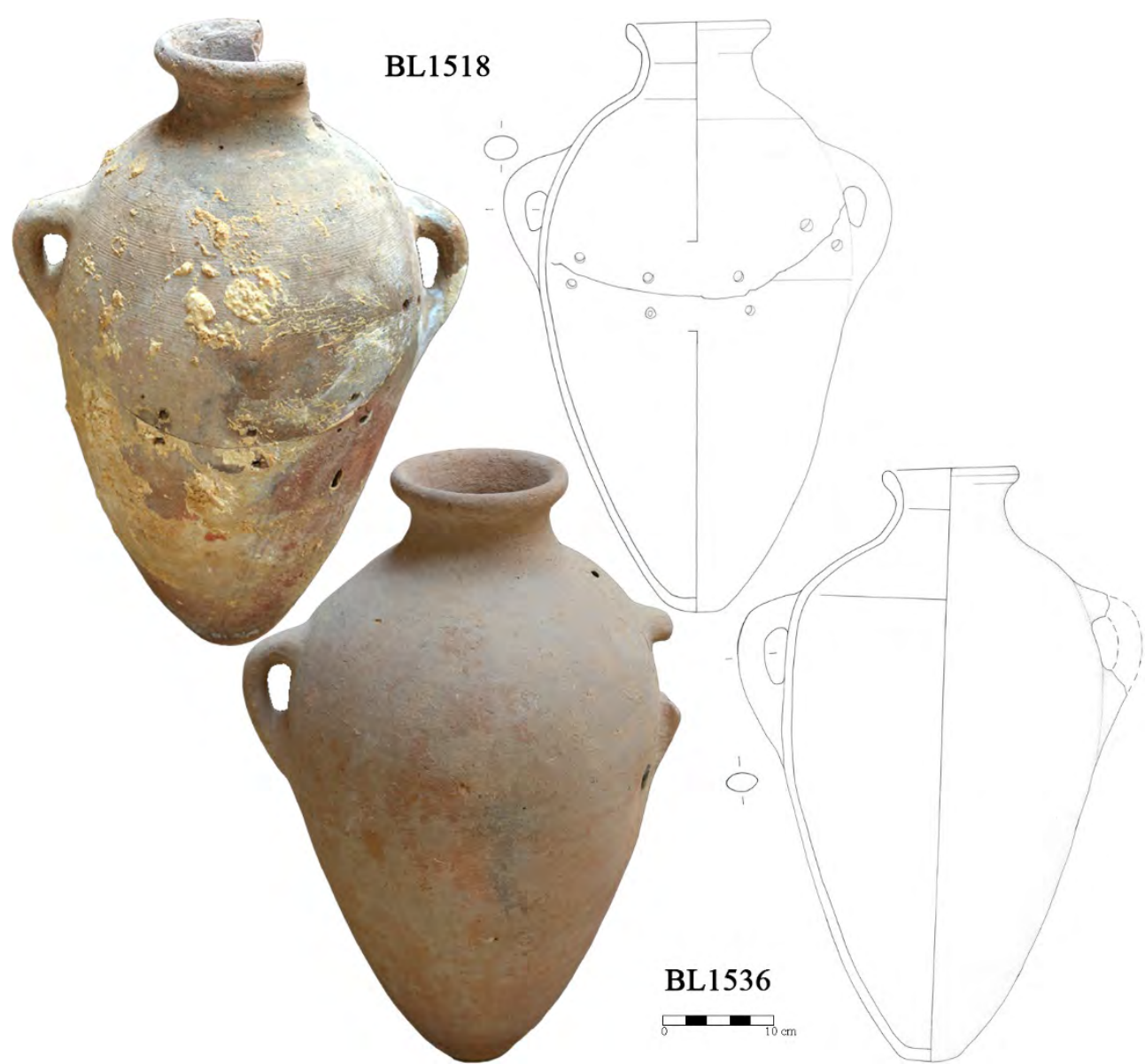

Fig. 46 - Two Middle Bronze jars from Bardhaa necropolis (1:8).

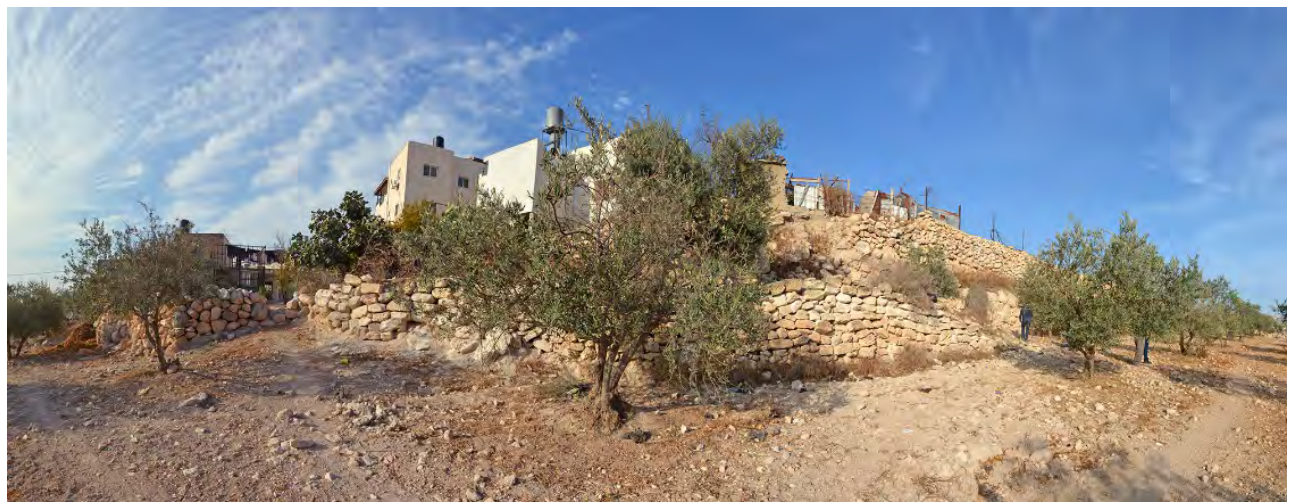

Fig. 47 - Modern terrace wall overlapping the Iron Age fortifications at Khirbet el-Kôm. 


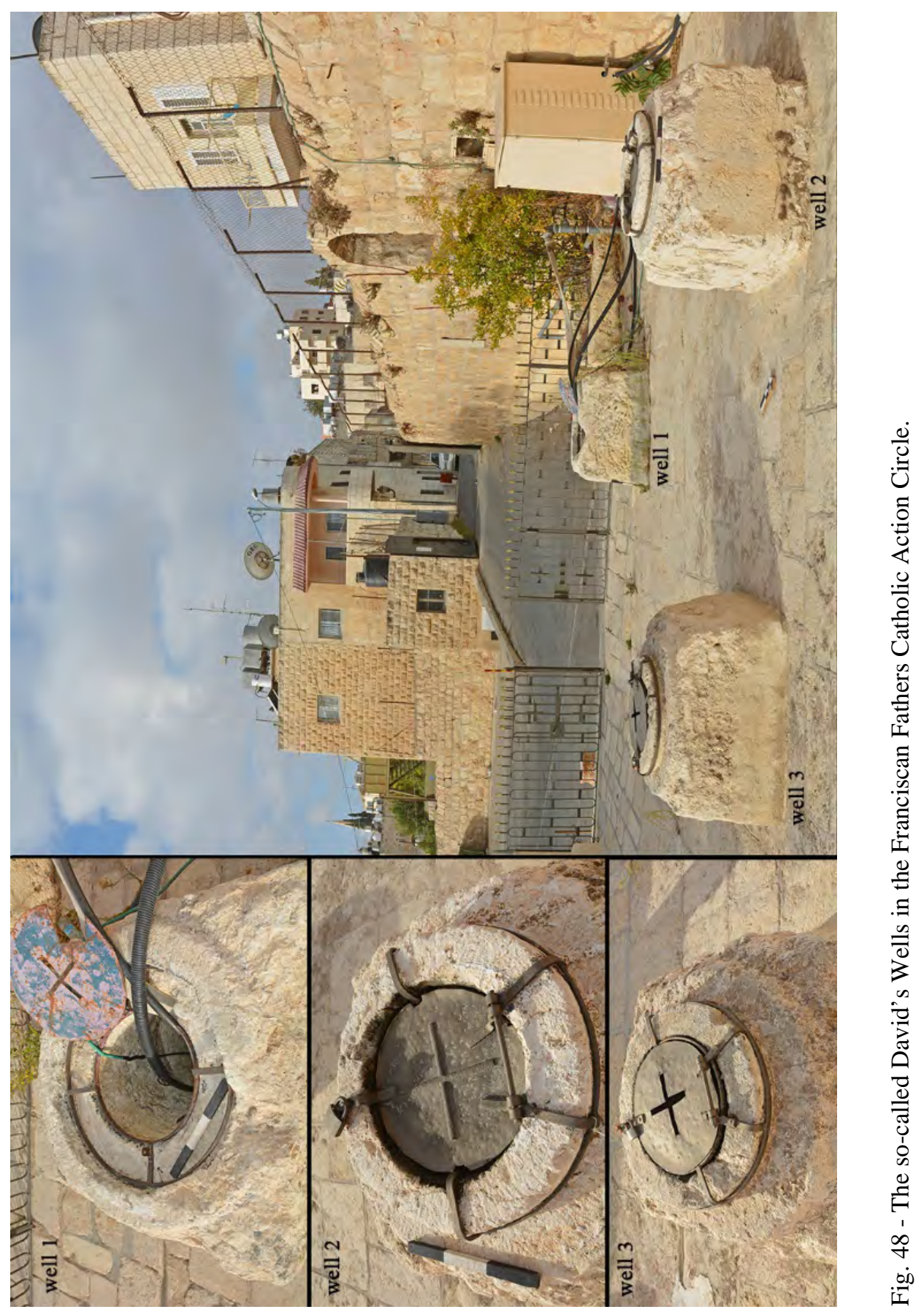




\section{ARABIC ABSTRACT}

معالم اثرية جديدة في بيت لحم /فلسطين

التنقيات الاثرية الانقاذية لموسم عام 2016 من قبل دائرة الاثار الفلسطسينية وجامعة لاسابينز الروما الايطالية

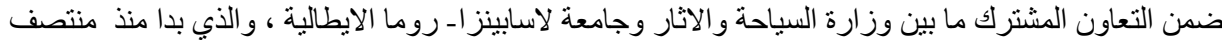

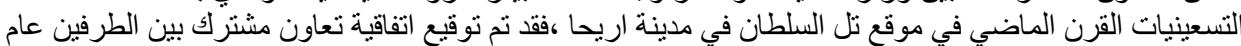

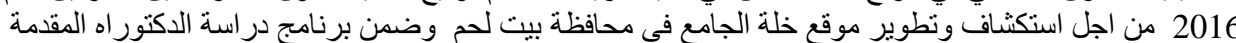

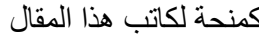

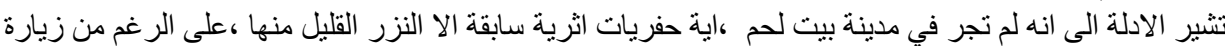

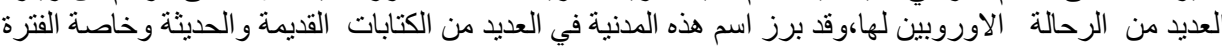

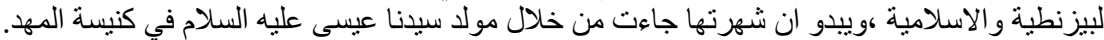

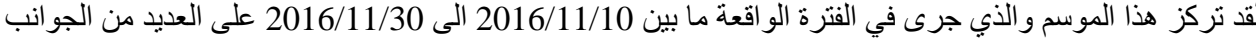

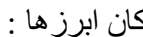

1-استكمال توثيق المو اد المكتشفة في حفرية عام 2014و عام 2015 في موقع خلة الجامع من خلال الرسم و التصوير

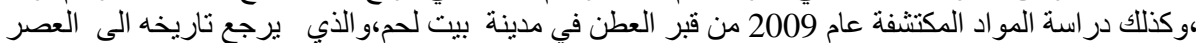

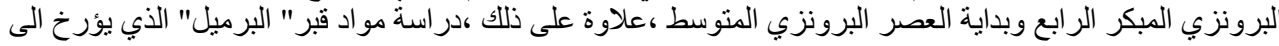

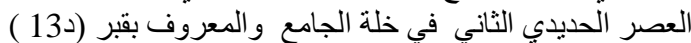

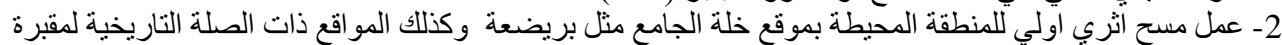

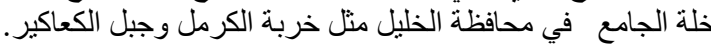

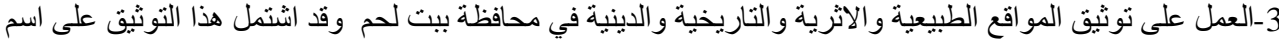

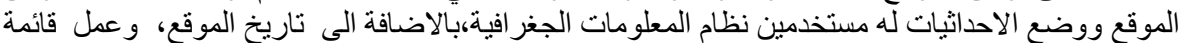

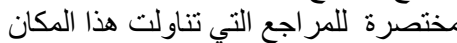

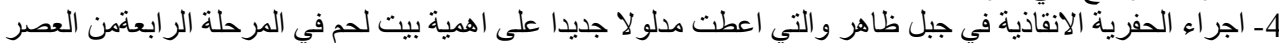

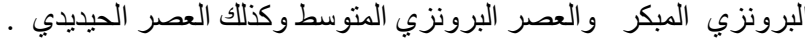

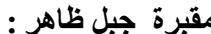

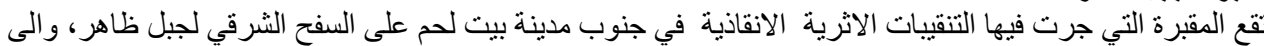

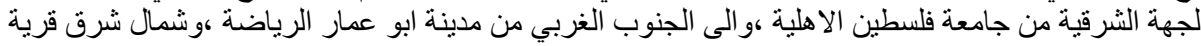

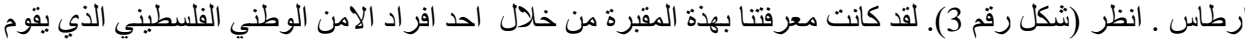

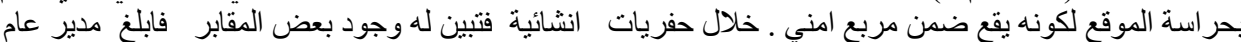

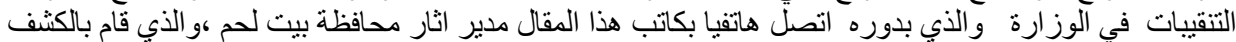

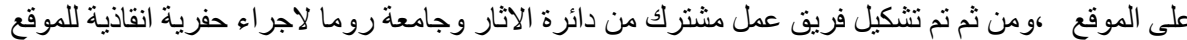

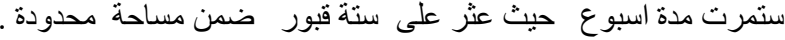

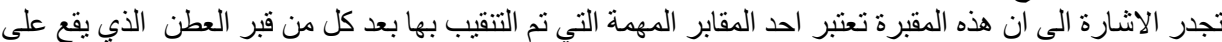

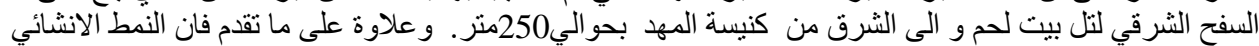

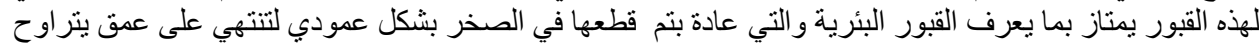

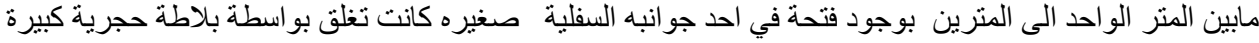

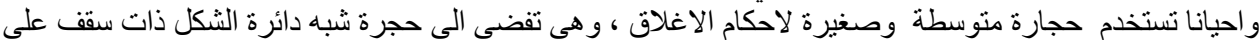

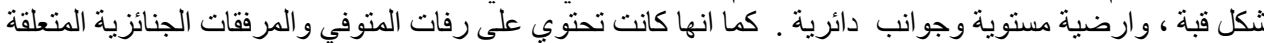

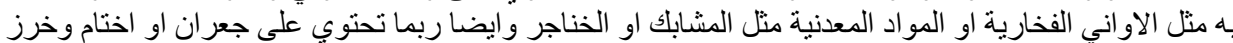

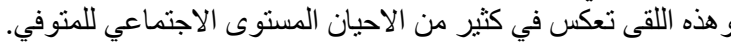

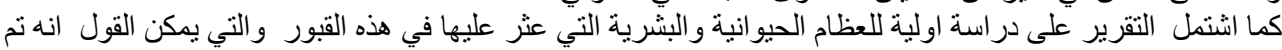
التعرف على اعمار وجنس المنوفين ورانئ وانماط و اتجاه الدفن في هذه التمقبرة. 


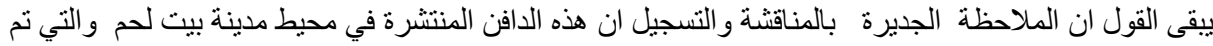

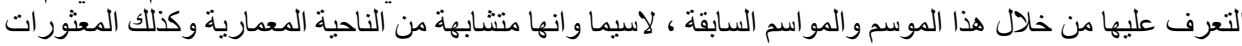

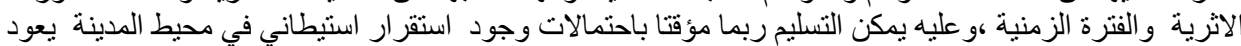

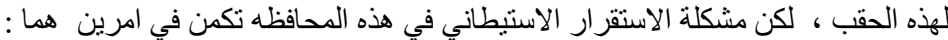

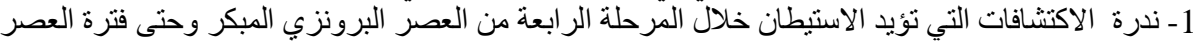

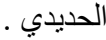

2- عدم وجود مسوحات اثرية التي من خلالها يمكن التعرف على مو اقع الاستقر ار بالاضافة الى النشاط العمر اني

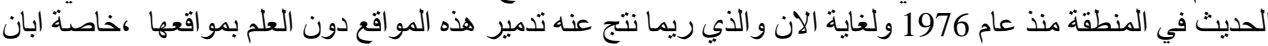

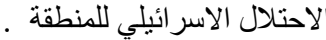

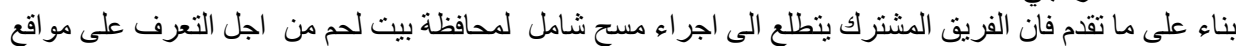

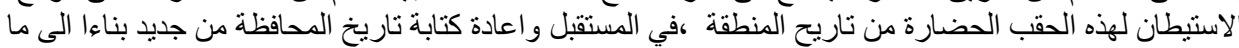

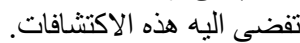
محمد غياظه مدير اثار محافظة بيت لحمه 